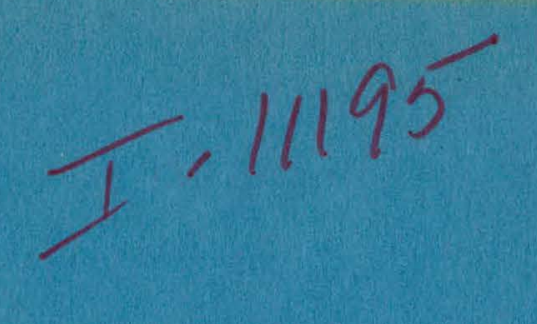

$$
\begin{aligned}
& \text { Dr. } 1766-3 \\
& \text { ANL/CNSV-41 }
\end{aligned}
$$

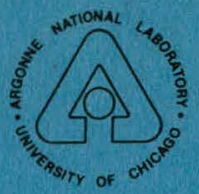

\title{
Energy and Materials Flows in the Iron and Steel Industry
}

\author{
F. T. Sparrow
}
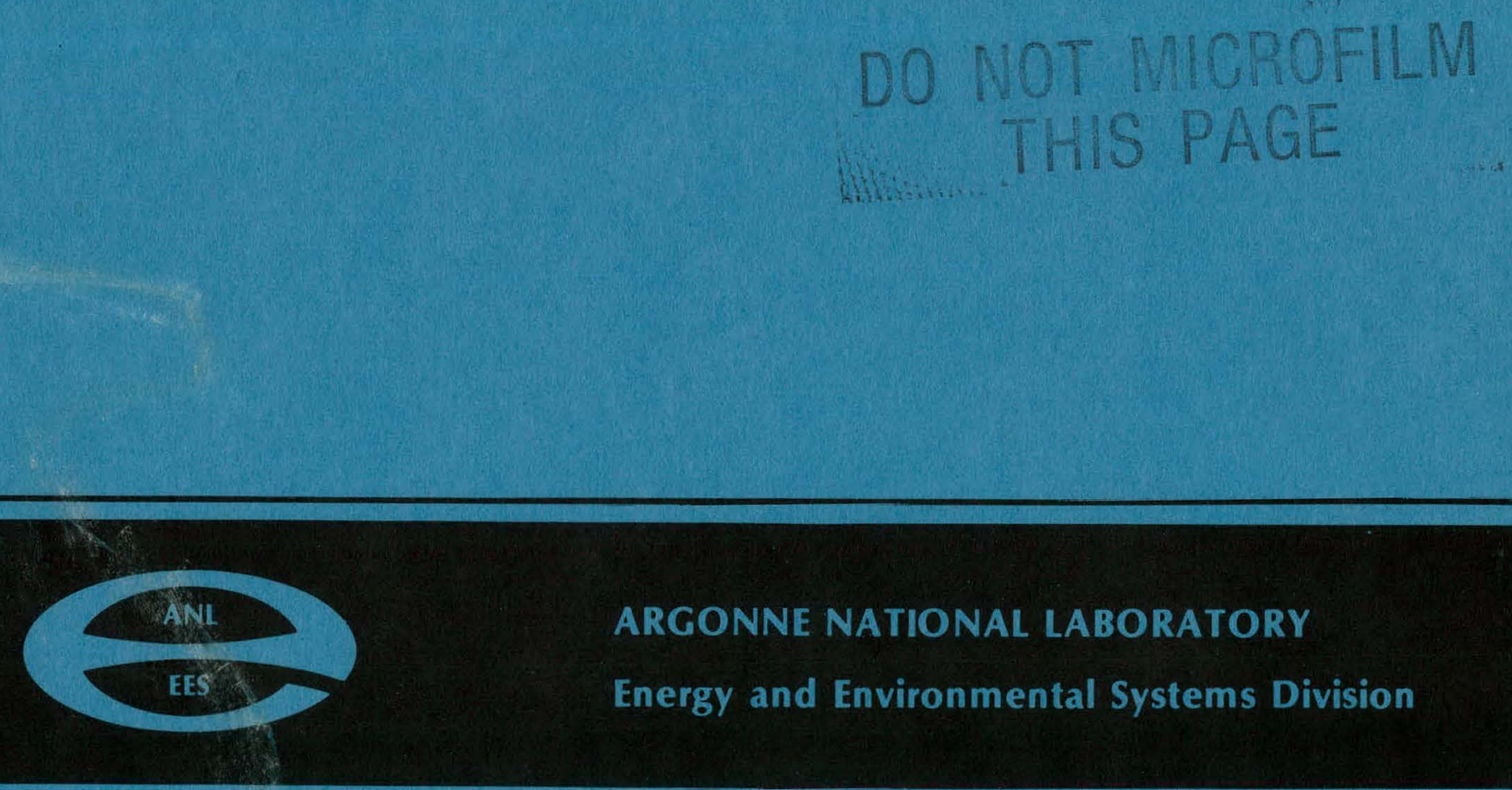

\section{ARGONNE NATIONAL LABORATORY \\ Energy and Environmental Systems Division}




\section{DISCLAIMER}

This report was prepared as an account of work sponsored by an agency of the United States Government. Neither the United States Government nor any agency Thereof, nor any of their employees, makes any warranty, express or implied, or assumes any legal liability or responsibility for the accuracy, completeness, or usefulness of any information, apparatus, product, or process disclosed, or represents that its use would not infringe privately owned rights. Reference herein to any specific commercial product, process, or service by trade name, trademark, manufacturer, or otherwise does not necessarily constitute or imply its endorsement, recommendation, or favoring by the United States Government or any agency thereof. The views and opinions of authors expressed herein do not necessarily state or reflect those of the United States Government or any agency thereof. 


\section{DISCLAIMER}

Portions of this document may be illegible in electronic image products. Images are produced from the best available original document. 


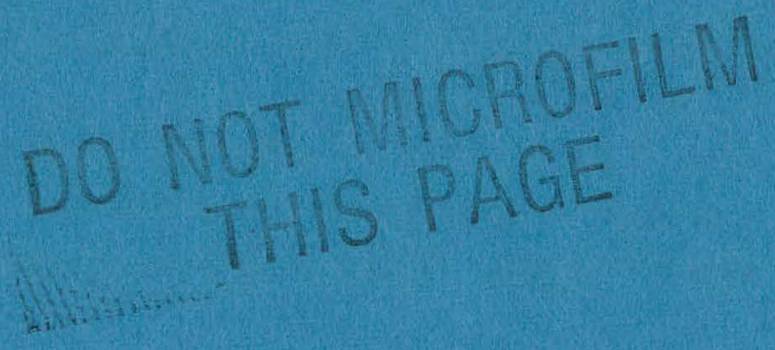

DISCLAIMER

This report was prepared as an account of work sponsored by an agency of the United States Government. Neither the United States Government nor any agency thereof, nor any of their employees, makes any warranty, express or implied, or assumes any legal liability or responsibility for the accuracy, completeness, or usefulness of any information, apparatus, product, or process disclosed, or represents that its use would not infringe privately owned rights. Reference herein to any specific commercial product, process, or service by trade name, trademark, manufacturer, or otherwise, does not necessarily constitute or imply its endorsement, recommendation, or favoring by the United States Government or any agency thereof. The views and opinions of authors expressed herein do not necessarily state or reflect those of the United States Government or any agency thereof.

Printed in the United States of America

Available from

National Technical Information Service

U. S. Department of Commerce

5285 Port Royal Road

Springfield, VA 22161

NTIS price codes

Printed copy: A06

Microfiche copy: A01 

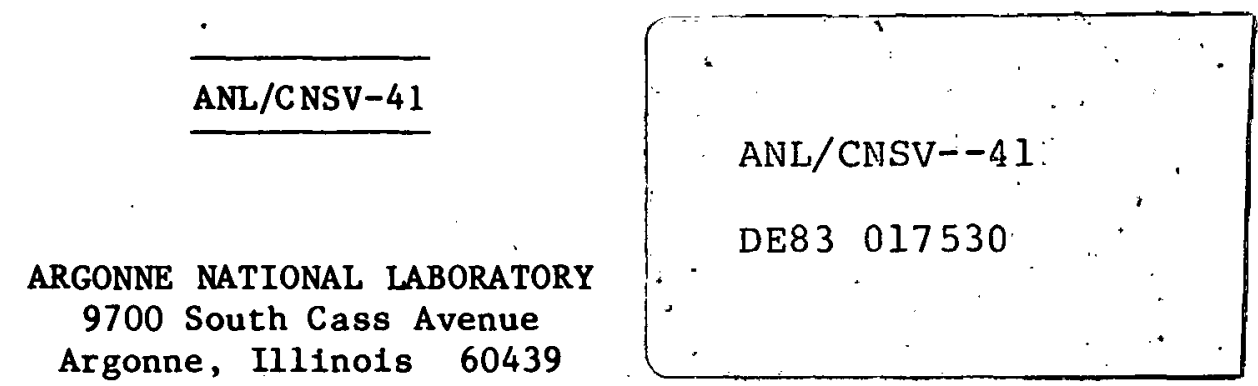

ENERGY AND MATERIALS FLOWS IN

THE IRON AND STEEL INDUSTRY

by

- F.T. Sparrow

Purdue University

prepared for

Energy and Environmental Systems Division

Special Projects and Industrial Applications Group

under Argonne Purchase Order 028260

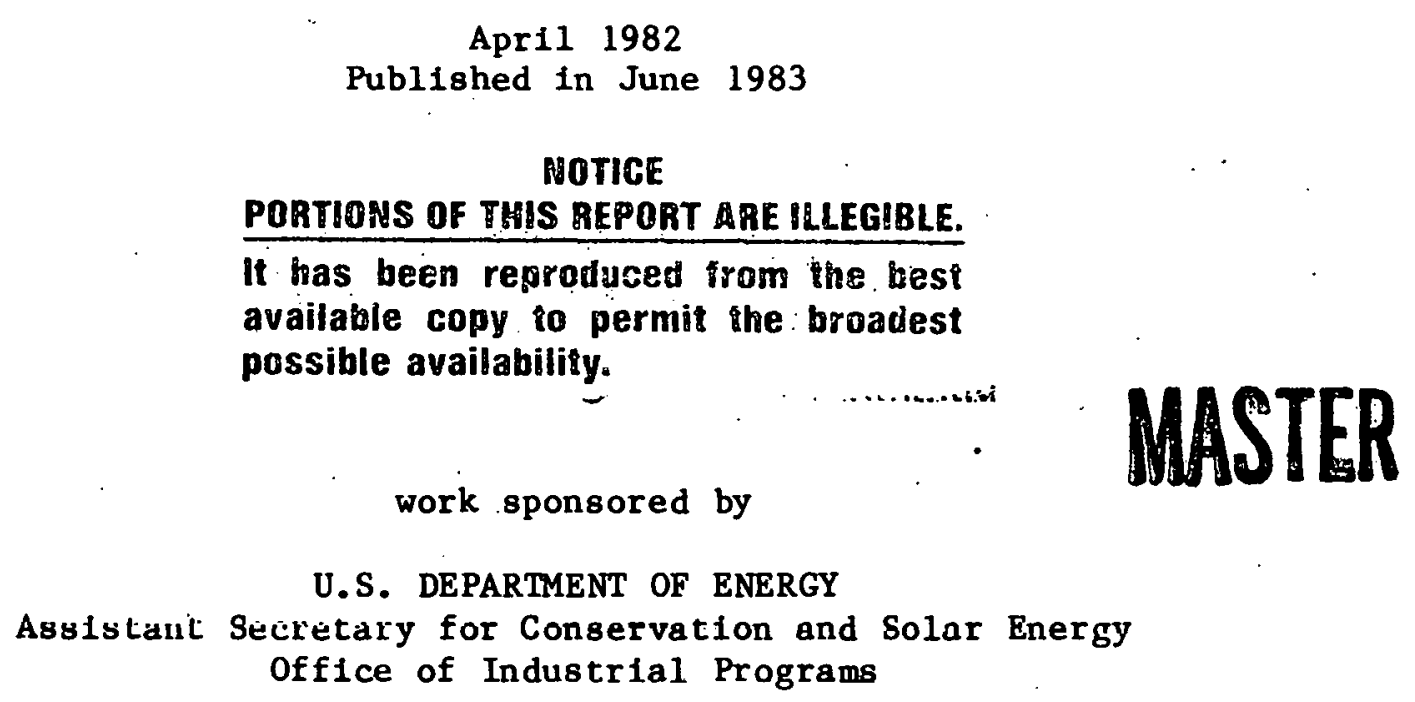




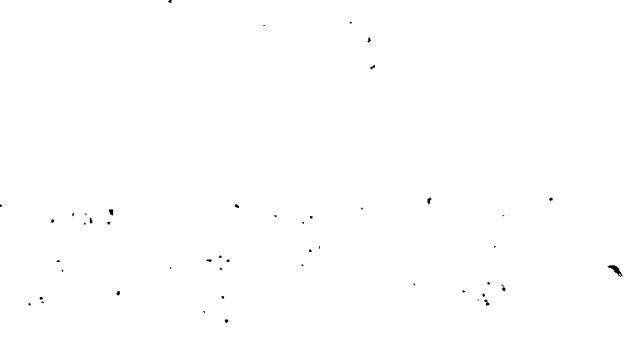

\section{DISCLAIMER}

This report was prepared as an account of work sponsored by an agency of the United States Government. Neither the United States Government nor any agency thereof, nor any of their employees, makes any warranty. express or implicd, ù assumes any legal liability us responsibility for the accuraoy, immpleteness, or usefulness of any information, apparatus, product, or process disclosed, or represents that its use would not infringe privately owned rights. Reference berein to any specific commercial product, process, or service by trade name, trademark, manufacturer, or otherwise does not necessarily constitute or imply its endorscment, recommendation, or favoring by the United States Government or any agency thereof. The views and opinions of authors expressed herein do not necessarily state or reflect those of the United States Government or any agency thereof. 
CONTENTS

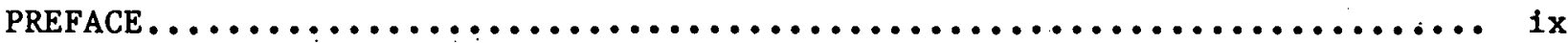

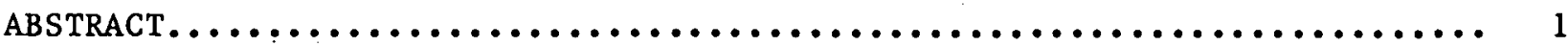

$1 \quad$ INTRODUCTION........................................... 1

1.1 Properties and Uses of Iron, Stee1, and Steel Alloys.......... 1

1.2 Materials Substitution.............................. 3

2 THE IRON AND STEEL INDUSTRY $\ldots \ldots \ldots \ldots \ldots \ldots \ldots \ldots \ldots \ldots \ldots \ldots \ldots \ldots \ldots \ldots \ldots \ldots \ldots \ldots$

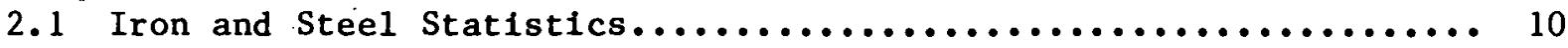

2.2 Indust ry structure................................. 13

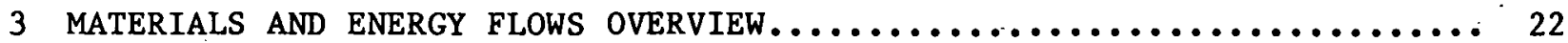

3.1 Data Sources................................... 22

3.2 Total Energy dild Malerlals Flows........................ 24

3.3 Flows by Major Process............................... 28

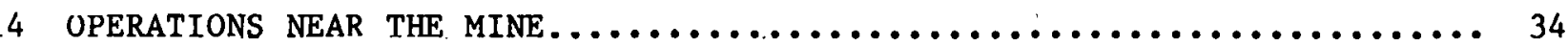

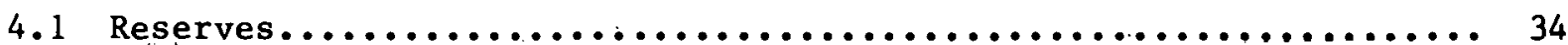

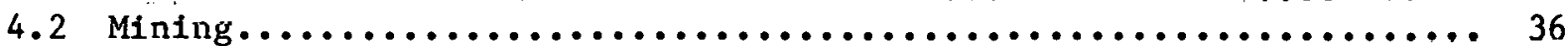

4.3 Crushing, Concentration, and Pelletization................ 40

5 SINTERING PLANT...................................... 46

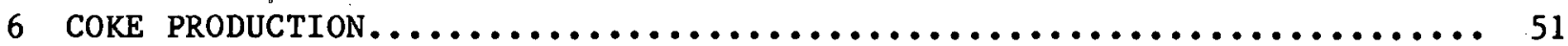

6.1 Coke and Its By-Products........................... 51

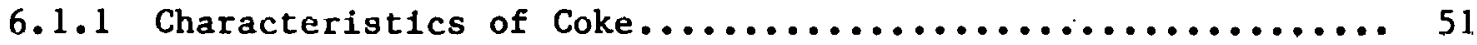

6.1 .2 Production Process.............................. 51

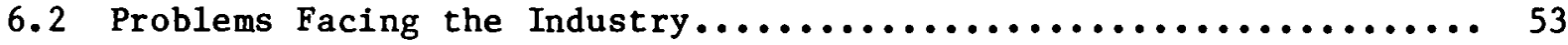

6.3 Energy Conservation Measures for Coke Ovens.................. 56

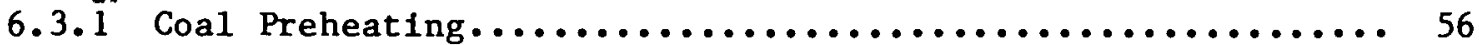

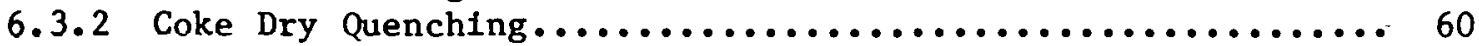

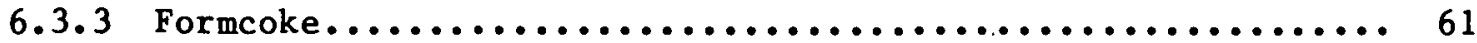

6.4 Nonrecovery Coke Making............................... 62

7 THE BLAST FURNACE AND EXTERNAL DESULFURIZATION................. 63

7.1 The Blast Furnace................................ 63

7.1 .1 Pig Iron Productinn Process....................... 63

7.1 .2 Energy and Materials Use...................... 65

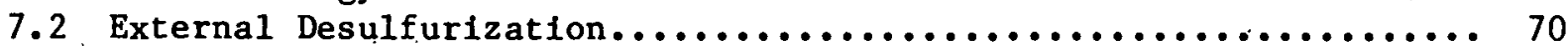

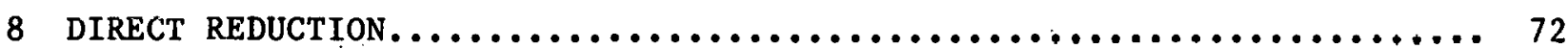

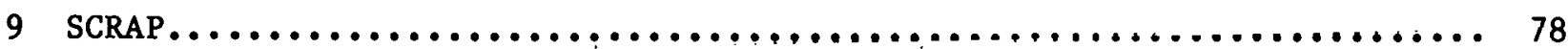


9.1 Energy Use in the Scrap Industry.................... 78

9.2 Supply and Demand for Scrap.......................... 81

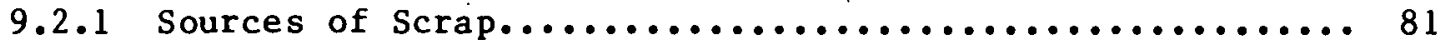

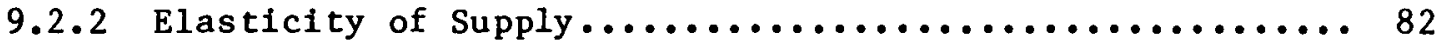

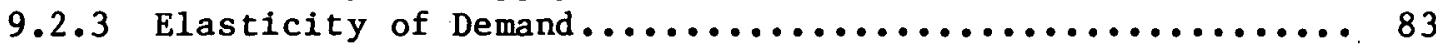

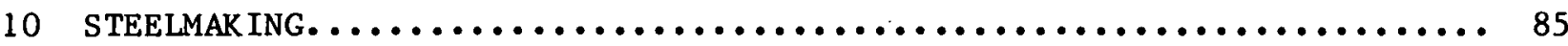

10.1 Open Hearth Furnaces............................. 85

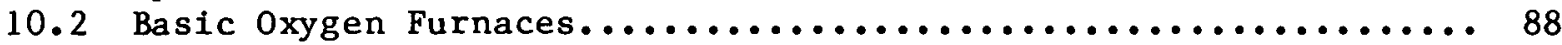

10.3 Electric Arc Furnaces.............................. 93

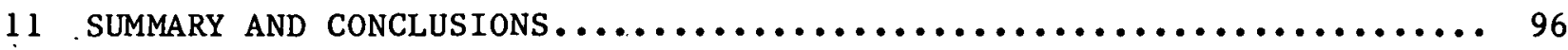

REFERENCES ............................................ 99

\section{TABLES}

1.1 Typical Properties of Selected Metals....................... 2

1.2 Roles of Ferroalloys in Steel Production................... 3

1.3 Net Shipments of Steel Products by Market Classification,

All Grades........................................ 4

2.1 World Raw Steel Production, $1956-1980 \ldots \ldots \ldots \ldots \ldots \ldots \ldots \ldots \ldots \ldots \ldots \ldots$

2.2 U.S. Imports and Exports of Steel. Mill Products, 1956-1980........ 13

2.3 Index of Steel Industry Prices and Costs, 1965-1978............ 14

2.4 Selected Financial Data for the U.S. Steel Industry, 1970-1978..... 15

2.5 Summary Statistics for Blast Furnaces and Steel Mills, 1977....... 19

2.6 Historical Statistics for SIC 3312 Blast Furnaces and

Steel Mills, 1963-1977............................... 20

2.7 Steel Company Profitability by Industry Segment, 1977-1978........ 21

3.1 Current Periodicals on Iron and Steel...................... 23

3.2 Total Energy Consumption in the United States and the Domestic Steel Industry................................ 24

3.3 Steel Industry Energy Consumption by Source.................. 25

3.4 1980 Domestic Energy and Materials Use by Energy and Materials Type..................................... 26 


\section{TABLES (Cont'd)}

3.5 1980 Domestic Energy and Materials Use by Major Process........... 30

3.6 Direct Energy Intensity per Ton of Product................. 32

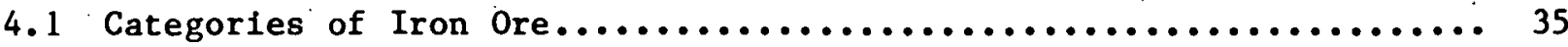

4.2 World Iron Ore Resources............................ 37

4.3 U.S. Iron Ore Production and Shipments, 1973-1980.............. 39

4.4 Consumption of Iron Ore at U.S. Iron and Steel Plants,

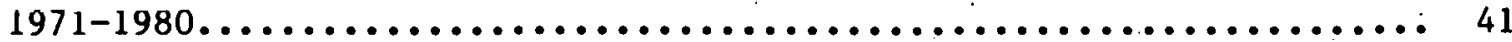

4.5 Direct Energy Intensities in Iron Ore Mining and Concentration..... 42

4.6 U.S. Pellet Plants.................................... 44

5.1 Sinter Production, $1973-1980 \ldots \ldots \ldots \ldots \ldots \ldots \ldots \ldots \ldots \ldots \ldots \ldots \ldots \ldots$

5.2 Energy Intensities in the Production of Iron Ore Sinter......... 50

6.1 Geographic Distribution of U.S. Coke Oven Capacity............. 54

6.2 End Uses of Coke Fines Produced in the United States, 1975-1980.... 55

6.3 Coke and Coking Coal Consumption in the United States,

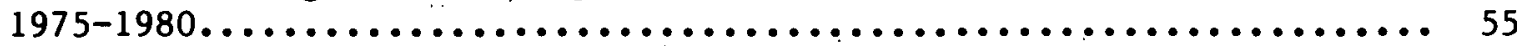

6.4 Coal Carbonized at Coke Plants, $1975-1979 \ldots \ldots \ldots \ldots \ldots \ldots \ldots \ldots \ldots \ldots$

6.5 Blast Furnace Output and Coke Consumption, 1964-1980............ 57

6.6 Energy Consumption to Manufacture Coke.................... 58

6.7 Coke Oven Conservation Options........................... 59

6.8. Formcoke Processes in the United States....................61

7.1 Direct and Indirect Energy Consumption In a Blast. Furnace, 1980.... 66

7.2 Materlals Used in Blast Furnaces, 1973-1980................. 67

8.1 Direct Reduction Plants Constructed or Scheduled for

Completion by $1980 \ldots \ldots \ldots \ldots \ldots \ldots \ldots \ldots \ldots \ldots \ldots \ldots \ldots \ldots \ldots \ldots \ldots \ldots \ldots \ldots$

8.2 Dirèct Reduction Processes............................ 74

8.3 Operating Direct Reduction P1ants Based on Coal or Coke Breeze..... 75

8.4 Energy Comparison of Direct Reduction Processes................ 76 


\section{TABLES (Cont'd)}

9.1 Consumption of Recoverable Materials in the Iron and Steel

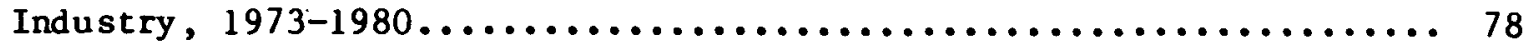

9.2 Estimates of Energy Use per Ton of Scrap................... 79

10.1 Raw Steel Production by Type of Furnace, $1960-1980 \ldots \ldots \ldots \ldots \ldots \ldots$

10.2 Direct and Indirect Energy Consumption in Open Hearth

Steel Production, $1980 \ldots \ldots \ldots \ldots \ldots \ldots \ldots \ldots \ldots \ldots \ldots \ldots \ldots \ldots \ldots \ldots \ldots . \ldots . \ldots \ldots$

10.3 Direct and Indirect Energy Consumption in Basic Oxygen

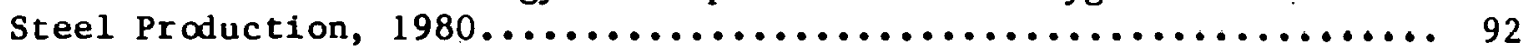

10.4 Di rect and Indirect Energy Consumption in Electric Furnace

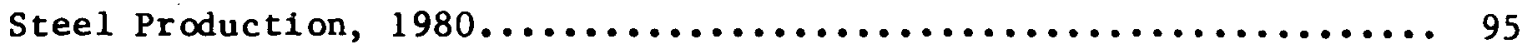

$11: 1$ Summary of Potential Areas for Energy Conservation in

Iron and steel Manufacture............................. 97

FIGURES

1.1 Change to Front-Wheel Drive........................... 7

2.1 Process Unit Interrelationships for Ironmaking, Steelmaking, and steel Forming.................................... 11

2.2 Annual Average Rates of Return and Inflation in the

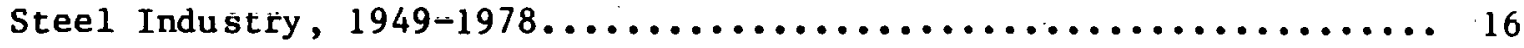

2.3 Geographical Distribution of the U.S. Iron and Steel Industry...... 17

3.1 Energy Use in the Steelmak1ng Industry, 1972-1980............ 33

4.1 Beneficiation of Magnetic Taconites...................... 36

4.2 Materials Flows in Min1ng and Benef1c1ation, $1980 \ldots \ldots \ldots \ldots \ldots \ldots$

4.3 Proportioning of Iron in Different Iron-bearing Materials in

U.S. Blast Furnaces................................. 40

5.1 Materials Flows in the Blast Furnace Area, $1980 \ldots \ldots \ldots \ldots \ldots \ldots \ldots$

5.2 Typical Sintering Machine............................ 48

6.1 Typical Coke. Oven................................ 52

7.1 Typlcal Modern Blast Furnace......................... 64

7.2 Factors Governing Blast Furnace Productivity................ 65 


\section{FIGURES (Cont'd)}

10.1 Typical Open Hearth Furnace............................. 86

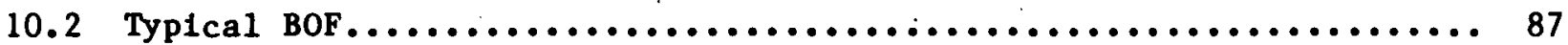

10.3 Typical Electric Arc Furnace.............................. 88

10.4 Materials and Energy Flows in Steelmaking, $1980 \ldots \ldots \ldots \ldots \ldots \ldots \ldots \ldots$ 


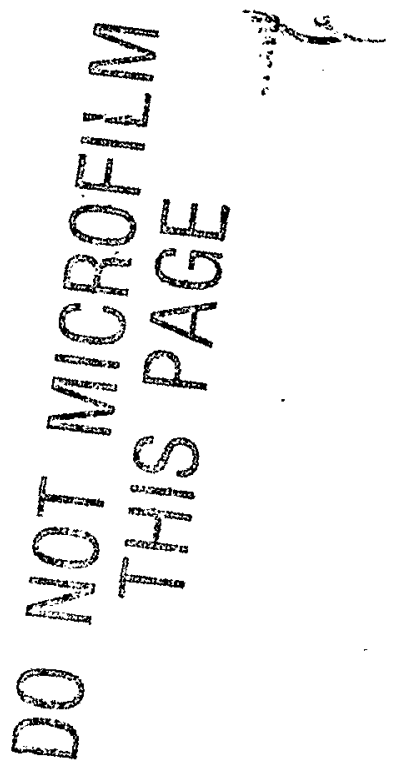

viil 


\section{PREFACE}

This report is one of a series being prepared for the U.S. Department of Energy, Office of Industrial Programs, on energy and materials flows in energy-intensive industries. Each report gives an overview of the particular industry, including its products, corporate structure, and present and emerging technologies. Suppliers and customers of major energy-consuming industries will gain a better understanding of the effects of changes in the cost and availability of energy. In cases where firms can substitute one material input for another, the reports will help these firms consider the impact of changes in energy supply on possible alternatives. Government analysts responsible for expediting industrial energy conservation should profit from having a compact and ready source of background information to help place proposed. projects in perspective and to serve as a point of departure for specific evaluations. The industries studied to date and the current status of the corresponding reports are listed below.

The information presented in the report series is derived from previous reports; government and industry statistics, trade and technical publications, patents, textbooks, industry interviews, and plant visits. Some of these sources provide incomplete, out-of-date, or conflicting data; therefore, ANL staff perform additional research to supplement, update, and reconcile the sources.

Energy and Materials Reports

Industry

Status (as of June 1983).

Fabrication of aluminum products

Fabrication of iron and steel semf finished products

olefins and their derivatives

Petroleum refining

Copper

Alr products

Pulp and paper

Cement

Primary alumi num
Published 1979 (ANL/CNSV-3)

Published 1979 (ANL/CNSV-8)

Published 1980 (ANL/CNSV-9)

Published 1981 (ANL/CNSV-10)

Published 1981 (ANL/CNSV-11)

Published 1981 (ANL/CNSV-15)

Published 1981 (ANL/CNSV-16)

Published 1981 (ANL/CNSV-17)

Published 1981 (ANL/CNSV-21) 
ENERGY AND MATERIALS FLOWS IN

THE IRON AND STEEL INDUSTRY

by

F.T. Sparrow

ABSTRACT

Past energy - consumption trends and future energy1 conservation opportunities are investigated for the nation's Iron and steel industry. It is estimated that, in 1980, the industry directly consumed approximately $2.46 \times 10^{15} \mathrm{Btu}$ of energy (roughly $3 \%$ of total U.S. energy consumption) to produce 111 million tons of raw steel and to ship 84 million tons of steel products. Direct plus indirect consumption is estimated to be about $3.1 \times 10^{15} \mathrm{Btu}$. Of the set of conservation technologies identified, most are judged to be ready for commercialization if and when the industry's capital formation and profitability problems are solved and the gradual predicted increase in energy prices reduces the payback periods to acceptable levels.

\section{INTRODUCTION}

\subsection{PROPERTIES AND USES OF IRON, STEEL, AND STEEL ALLOYS}

The physical and mechanical properties of iron, steel, and steel alloys are compared with those of other selected metals in Table 1.1. Hot metal contains $3-5 \%$ carbon along with other impurities that remain from the reduction process in the blast furnace. Carbon steel contains no more than $1 \%$ carbon, while stainless steel is an alloy of steel and chromium. These compositional differences explain the wide variation in the properties given in Table 1.1. Table 1.2 gives the impact of adding various alloying materials to steel.

Because of its relatively high thermal conductivity and malleability, iron is utilized directly in gray, malleable, and ductile castings for various purposes that require these properties; for example, engine blocks and cookware require conductivity, and ornamental structures and fences require malleability. The vast majority (95\% in 1980) of iron produced in blast furnaces is converted into steel in steel furnaces, where additives (such as chromium, manganese, nickel, and molybdenum) and the type of processing (hotand/or cold-rolling, galvanizing, annealing, tempering, plckling) determine the properties of the final product and hence its use. 1 End use shipments by 
Table 1.1 Typical Properties of Selected Metals

\begin{tabular}{|c|c|c|c|c|c|}
\hline Metal & $\begin{array}{c}\text { Resistivity } \\
\text { at } 20^{\circ} \mathrm{C} \\
(\mathrm{cm})\end{array}$ & $\begin{array}{c}\text { Thermal } \\
\text { Conductivity } \\
\text { at } 0^{\circ} \mathrm{C} \\
\left(\text { Btu/hr ft }{ }^{\circ} \mathrm{F}\right)\end{array}$ & $\begin{array}{l}\text { Specific } \\
\text { Gravity }\end{array}$ & $\begin{array}{c}\text { Tensile } \\
\text { sţrength } \\
\left(1 \mathrm{C}^{3} \text { lb/1n.) }\right.\end{array}$ & $\begin{array}{l}\text { Melting } \\
\text { Point } \\
\left({ }^{\circ} \mathrm{C}\right)\end{array}$ \\
\hline Aluminum & 2.8 & 117 & 2.7 & 30 & 659 \\
\hline Brass $^{a}$ & 7 & 56 & 8.6 & 70 & 900 \\
\hline Copper & 1.7 & 224 & 8.89 & $30^{b}, 60^{c}$ & 1,083 \\
\hline Gold & 2.4 & 172 & 19.3 & 20 & 1,063 \\
\hline Iron, Ingot & 9 & 77 & 6 & 45 & 1,538 \\
\hline $\begin{array}{l}\text { Lead } \\
\text { Mone } 1 \mathrm{~d}\end{array}$ & $\begin{array}{l}22 \\
42\end{array}$ & $\begin{array}{l}20 \\
19\end{array}$ & $\begin{array}{r}11.4 \\
8.9\end{array}$ & $\begin{array}{r}3 \\
160\end{array}$ & $\begin{array}{r}327 \\
1,300\end{array}$ \\
\hline $\begin{array}{l}\text { Nickel } \\
\text { Phosphor bronze }\end{array}$ & $\begin{array}{l}7.8 \\
7.8\end{array}$ & $\begin{array}{c}36 \\
30-40\end{array}$ & $\begin{array}{l}8.9 \\
8.9\end{array}$ & $\begin{array}{r}120 \\
25\end{array}$ & $\begin{array}{r}1,452 \\
750\end{array}$ \\
\hline Platinum & 10 & 39 & 21.4 & 50 & 1,755 \\
\hline Silver & 1.6 & 242 & 10.5 & 42 & 960 \\
\hline Steel, carbon & 10 & 56 & 7.86 & 65 & 1,515 \\
\hline Steel, stainless & 72 & 19 & 8.02 & 230 & 1,427 \\
\hline Tin & 11.5 & 36 & 7.3 & 4 & 232 \\
\hline Tungsten, drawn & 5.6 & 116 & 19 & 500 & 3,400 \\
\hline Zinc & 5.8 & 65 & 7.1 & .10 & 419 \\
\hline
\end{tabular}

a $70 \%$ copper, $30 \%$ zinc.

bAnnealed.

cHard drawn.

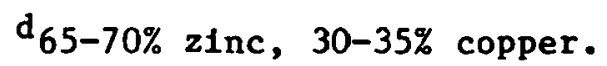

e $90-95 \%$ copper, 5-10\% t1n, remalnder phosphorus.

Source: Ref: 2 . 
Table 1.2 Roles of Ferroalloys in Steel Production

\begin{tabular}{|c|c|c|c|c|c|c|}
\hline Role & Chromt um & Columbium & Manganese & Molybdenum & Nicke l & Vanadium \\
\hline $\begin{array}{l}\text { Ties up or removes oxygen } \\
\text { Ties up or removes sulfur } \\
\text { Increases tensile strength } \\
\text { Increases ductility } \\
\text { Improves low-temperature } \\
\text { Impact resistance } \\
\text { Increases hardenability } \\
\text { Improves high-temperature } \\
\text { Btrength } \\
\text { Improves resistance to } \\
\text { corrosion and oxidation } \\
\text { Increases toughness } \\
\text { Improves resistance } \\
\text { to abrasion }\end{array}$ & $\begin{array}{l}\mathbf{x} \\
\mathbf{x} \\
\mathbf{x}\end{array}$ & $\begin{array}{l}\mathrm{x} \\
\mathrm{x}\end{array}$ & $\begin{array}{l}\mathbf{x} \\
\mathbf{x} \\
\mathbf{x} \\
\mathbf{x}\end{array}$ & $\begin{array}{l}\mathbf{x} \\
\mathbf{x} \\
\mathbf{x} \\
\mathbf{x} \\
\mathbf{x}\end{array}$ & $\begin{array}{l}\mathbf{x} \\
\mathbf{x}\end{array}$ & $\begin{array}{l}\mathbf{x} \\
\mathbf{x} \\
\mathbf{x}\end{array}$ \\
\hline
\end{tabular}

market classification for 1973-1980 are given in Table 1.3. A comparison of the 1974 percentage distribution with that of 1979 (both "good" years for the steel industry) shows a fair degree of stability in market shares, although certain markets (containers, fasteners, construction, and, in particular, autos), which accounted for $20 \%$ of steel sales over the past decade; show a decline over time, while others ( 011 and gas) show a marked increase.

\subsection{MATERIALS SUBSTITUTION}

Figure 1.1 shows which automobile parts have been eliminated by the change to front-wheel drive. Downsizing has already cut into steel demand. Further downstzing along with materials substitution -- especially of fiberreinforced plastics (FRPs) for bodies -- will reduce steel use even more. FRPs, which until recently were used primarily in marine hulls as a substitute for wood, are generally $25-35 \%$ resin and $30-75 \%$ reinforcement, depending on the strength requirements; the remainder is filler. Resins can be either thermoplastic ( $1 . e_{.}$, can be repeatedly softened and hardened) or thermosetting (irreversibly hardened). Even though thermoplastic resins (e.g., polyethylene, polyvinyl chloride, and polystyrene) account for over $75 \%$ of total plastics production, thermosetting resins -- in particular, unsaturated polyester -- account for over $90 \%$ of the FRP market because of their better mechanical properties. 4

Common FRP-reinforcing materials include fiberglass, asbestos (now being phased out), cotton, nylon, and cellulose. The next generation will likely include carbon-graphite (now used in tennis rackets) and siliconcarbide whiskers, the latter belng characterized as "the ultimate reinforcement, in that they (whiskers) have mechanical strengths equivalent to the forces between adjacent atoms." 4 . In 1979, Ford Motor Company produced an 
Table 1.3 Net Shipments of Steel Products (1ncluding carbon, alloy, and stainless steel) by Market Classification, All Grades $^{a}$ ( $10^{3}$ net tons)

\begin{tabular}{|c|c|c|c|c|c|c|c|c|c|c|c|c|c|c|c|c|}
\hline \multirow[b]{2}{*}{$\begin{array}{c}\text { Market } \\
\text { Classification }\end{array}$} & \multicolumn{2}{|c|}{1980} & \multicolumn{2}{|c|}{1979} & \multicolumn{2}{|c|}{1978} & \multicolumn{2}{|c|}{1977} & \multicolumn{2}{|c|}{1976} & \multicolumn{2}{|c|}{1975} & \multicolumn{2}{|c|}{1974} & \multicolumn{2}{|c|}{1973} \\
\hline & $\begin{array}{l}\text { Ship- } \\
\text { ments }\end{array}$ & $x$ & $\begin{array}{l}\text { Ship- } \\
\text { ments }\end{array}$ & 5 & $\begin{array}{l}\text { Ship- } \\
\text { ments }\end{array}$ & $x$ & $\begin{array}{l}\text { Sh1p- } \\
\text { ments }\end{array}$ & $\bar{z}$ & $\begin{array}{l}\text { Ship- } \\
\text { ments }\end{array}$ & $x$ & $\begin{array}{l}\text { Ship- } \\
\text { ments }\end{array}$ & $x$ & $\begin{array}{l}\text { Sh1p- } \\
\text { ments }\end{array}$ & $x$ & $\begin{array}{l}\text { Sh1p- } \\
\text { ments }\end{array}$ & $x$ \\
\hline $\begin{array}{l}\text { Steel for convert- } \\
\text { ing and processing }\end{array}$ & 4,117 & 4.9 & 5,058 & 5 & 4,612 & 4.7 & 3,679 & 4 & 4,036 & 4.5 & 3.255 & 4.1 & 4,486 & 4.1 & 4,714 & 4.2 \\
\hline $\begin{array}{l}\text { Independent for- } \\
\text { gers (not else- } \\
\text { where classified) }\end{array}$ & 933 & 1.1 & 1,154 & 1.3 & 1,192 & 1.2 & 998 & 1.1 & 952 & 1.1 & 1.098 & 1.4 & 1,339 & 1.2 & $1,21.3$ & 1.1 \\
\hline $\begin{array}{l}\text { Industrial } \\
\text { fasteners }\end{array}$ & 590 & 0.7 & 934 & 0.9 & 870 & 0.9 & 848 & $0 . \dot{9}$ & 912 & 1 & 675 & 0.8 & 1,331 & 1.2 & 1,278 & 1.1 \\
\hline $\begin{array}{l}\text { Steel service } \\
\text { centers and } \\
\text { distributors }\end{array}$ & 16,172 & 19.3 & 18,246 & 18.2 & 17,333 & 17.7 & 15,346 & 16.8 & 14,615 & $16 . \Xi$ & $12: 700$ & 15.9 & 20,400 & 18.6 & 20,383 & 18.3 \\
\hline $\begin{array}{l}\text { Construction, } \\
\text { Including } \\
\text { maintenance }\end{array}$ & 8,742 & 10.4 & 9,978 & 10 & 9,612 & 9.8 & 7,553 & 8.3 & 7,508 & 8.4 & $8: 119$ & 10.2 & 11,360 & 10.4 & 10,731 & 9.6 \\
\hline $\begin{array}{l}\text { Contractors' } \\
\text { products }\end{array}$ & 3,148 & 3.8 & 3,745 & 3.7 & 3,480 & 3.6 & 4,500 & 4.9 & 4,502 & 5 & 3.927 & 4.9 & 6,249 & 5.7 & 6,459 & 5.8 \\
\hline Subtotal & 11,890 & 14.2 & 13,723 & 13.7 & 13,092 & 13.4 & 12,053 & 13.2 & 12,010 & 13.4 & 12,046 & 15.1 & 17,609 & 16.1 & 17,190 & 15.4 \\
\hline Automot1ve & & & & . & & & & & & & & & & & & \\
\hline $\begin{array}{l}\text { Vehicles, parts, } \\
\text { etc. }\end{array}$ & 11,855 & 14.2 & 18,099 & 18 & 20,651 & 21.1 & 20,882 & 22.9 & 20,667 & 23.1 & 14,750 & 18.4 & 18,256 & 16.7 & 22,468 & 20.2 \\
\hline $\begin{array}{l}\text { Independent } \\
\text { forgers }\end{array}$ & 269 & 0.3 & 522 & 0.5 & 602 & 0.6 & 608 & 0.7 & 684 & $0 . \varepsilon$ & 464 & 0.6 & 672 & 0.6 & 749 & 0.6 \\
\hline Subtotal & 12,124 & 14.5 & 18,621 & 18.5 & 21,253 & 21.7 & $2 i, 490$ & 23.6 & 21,351 & 23.9 & 15,214 & 19 & 18,928 & 17.3 & 23,217 & 20.8 \\
\hline
\end{tabular}

Ra11 transport

Preight cars,

passenger cars,

and locomotives 
Table 1.3 (Cont'd)

\begin{tabular}{|c|c|c|c|c|c|c|c|c|c|c|c|c|c|c|c|c|}
\hline \multirow[b]{2}{*}{$\begin{array}{c}\text { Market } \\
\text { Classification }\end{array}$} & \multicolumn{2}{|c|}{1980} & \multicolumn{2}{|c|}{1979} & \multicolumn{2}{|c|}{1978} & \multicolumn{2}{|c|}{1977} & \multicolumn{2}{|c|}{1976} & \multicolumn{2}{|c|}{1975} & \multicolumn{2}{|c|}{1974} & \multicolumn{2}{|c|}{1973} \\
\hline & $\begin{array}{l}\text { Sh1p- } \\
\text { ments }\end{array}$ & $\%$ & $\begin{array}{l}\text { Ship- } \\
\text { ments }\end{array}$ & $\%$ & $\begin{array}{l}\text { Ship- } \\
\text { ments }\end{array}$ & 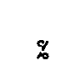 & $\begin{array}{l}\text { Ship- } \\
\text { ments }\end{array}$ & $\%$ & $\begin{array}{l}\text { Ship- } \\
\text { ments }\end{array}$ & $\%$ & $\begin{array}{l}\text { Ship- } \\
\text { ments }\end{array}$ & $\%$ & $\begin{array}{l}\text { Ship- } \\
\text { ments }\end{array}$ & $\%$ & $\begin{array}{l}\text { Ship- } \\
\text { ments }\end{array}$ & $\%$ \\
\hline $\begin{array}{l}\text { Rat ls and all } \\
\text { others }\end{array}$ & 1,271 & 1.5 & 1,668 & 1.7 & 1,361 & 1.4 & 1,529 & 1.7 & 1,587 & 1.8 & 1,316 & 1.6 & 1,285 & 1.2 & 1,231 & 1.1 \\
\hline Subtoral & 3,155 & 3.8 & 4,111 & 4.1 & 3,549 & 3.6 & 3,238 & 3.6 & 3,056 & 3.4 & 3,152 & 3.9 & 3.417 & 3.1 & 3,228 & 2.9 \\
\hline $\begin{array}{l}\text { Shipbuilding and } \\
\text { marline equipment }\end{array}$ & 1,201 & 1.4 & 924 & 0.9 & 845 & 0.9 & 869 & 1 & 969 & 1.1 & 1,413 & 1.8 & 1,339 & 1.2 & 1,019 & 0.9 \\
\hline $\begin{array}{l}\text { A1rcraft and } \\
\text { aeraspace }\end{array}$ & 53 & 0.1 & 60 & 0.1 & 60 & 0.1 & 63 & 0.1 & 59 & 0.1 & 69 & 0.1 & 79 & 0.1 & 69 & 0.1 \\
\hline $\begin{array}{l}\text { O1 } 1 \text { and gas } \\
\text { indust ry }\end{array}$ & 5,371 & 6.1 & 3,739 & 3.7 & 4,140 & 4.3 & 3,650 & 4 & 2,653 & 3 & 4,171 & 5.2 & 4,210 & .3 .9 & 3,405 & 3.1 \\
\hline $\begin{array}{l}\text { Mining, quarrying, } \\
\text { and lumbering }\end{array}$ & 454 & 0.6 & 508 & 0.5 & 486 & 0.5 & - & - & 536 & 0.6 & 596 & 0.7 & 644 & 0.6 & 534 & 0.5 \\
\hline Agricultural & & & & & . & & & & & & & & & & & \\
\hline Machinery & 852 & 1 & 1,306 & 1.3 & 1,080 & 1.1 & 1,017 & 1.1 & 1,209 & 1.4 & 1,055 & 1.3 & 1,236 & 1.1 & 1,155 & 1. \\
\hline Other & 388 & 0.5 & 665 & 0.7 & 725 & 0.7 & 631 & 0.7 & 575 & 0.6 & 374 & 0.5 & 623 & 0.6 & 617 & 0.6 \\
\hline Subtotal & 1,240 & 1.5 & 1,971 & 2 & 1,805 & 1.8 & 1,648 & 1.8 & 1,784 & 2 & $.1,429$ & 1.8 & 1,859 & 1.7 & 1,772 & 1.6 \\
\hline $\begin{array}{l}\text { Machinery, } \\
\text { industrial equip- } \\
\text { ment and tools }\end{array}$ & 4,543 & 5.4 & 5,996 & 6 & 5,992 & 6.1 & 5,566 & 6.1 & 5,180 & 5.8 & 5,173 & 6.5 & 6,440 & $5.9^{\circ}$ & 6,351 & 5.7 \\
\hline $\begin{array}{l}\text { Electrical } \\
\text { equipment }\end{array}$ & 2,441 & 2.9 & 2,819 & 2.8 & 2,811 & 2.9 & 2,639 & 2.9 & 2,671 & 3 & 2,173 & 2.7 & 3,242 & 3 & 3,348 & 3 \\
\hline $\begin{array}{l}\text { Applifances, uten- } \\
\text { sils, and cutlery }\end{array}$ & 1,725 & 2.1 & 2,140 & 2.1 & 2,094 & 2.1 & 2,129 & 2.3 & 1,950 & 2.2 & 1,653 & 2.1 & 2,412 & 2.2 & 2,747 & 2.5 \\
\hline $\begin{array}{l}\text { Other domestic } \\
\text { and commercial } \\
\text { equipment }\end{array}$ & 1,701 & 2 & 2,073 & 2.1 & 1,889 & 1.9 & 1,846 & 2 & 1,813 & 2 & 1,390 & 1.7 & 1,941 & 1.8 & 1,990 & 1.8 \\
\hline
\end{tabular}


Tabie 1.3 (Cont'd)

\begin{tabular}{|c|c|c|c|c|c|c|c|c|c|c|c|c|c|c|c|c|}
\hline \multirow[b]{2}{*}{$\begin{array}{l}\text { Market } \\
\text { Classification }\end{array}$} & \multicolumn{2}{|c|}{1980} & \multicolumn{2}{|c|}{1979} & \multicolumn{2}{|c|}{1978} & \multicolumn{2}{|c|}{1977} & \multicolumn{2}{|c|}{1976} & \multicolumn{2}{|c|}{1975} & \multicolumn{2}{|c|}{1974} & \multicolumn{2}{|c|}{1973} \\
\hline & $\begin{array}{l}\text { Sh1p- } \\
\text { ments }\end{array}$ & $\%$ & $\begin{array}{l}\text { Ship- } \\
\text { merits }\end{array}$ & $\%$ & $\begin{array}{l}\text { Ship- } \\
\text { ments }\end{array}$ & $\%$ & $\begin{array}{l}\text { Ship-- } \\
\text { ments }\end{array}$ & $\%$ & $\begin{array}{l}\text { St:ip- } \\
\text { ments }\end{array}$ & $\%$ & $\begin{array}{l}\text { Ship- } \\
\text { ments }\end{array}$ & $\%$ & $\begin{array}{l}\text { Sh1p- } \\
\text { ments }\end{array}$ & $\%$ & $\begin{array}{l}\text { Ship- } \\
\text { ments }\end{array}$ & $\%$ \\
\hline $\begin{array}{l}\text { Containers, pack- } \\
\text { packaging, and } \\
\text { shipping materials }\end{array}$ & & & & & . & & & & & . & & & . & & & \\
\hline Cans, closures & $.4,163$ & 5 & 4,994 & 4.9 & 4,950 & 4.9 & 5,173 & 5.7 & 5,301 & 5.7 & $4,85 ̣$ & 6 & 6,349 & 5.8 & 6,070 & 5.5 \\
\hline $\begin{array}{l}\text { Barrels, drums, } \\
\text { shipping pa11s }\end{array}$ & 725 & 0.9 & 939 & 1 & 809 & 0.9 & 768 & 0.8 & 859 & 1 & 601 & 0.8 & 1,026 & 0.9 & 910 & 0.8 \\
\hline Other & 663. & 0.7 & 839 & 0.9 & 836 & 0.9 & 773 & 0.9 & 754 & 0.8 & $59 \Xi$ & 0.8 & 843 & 0.8 & 831 & 0.7 \\
\hline Subtotal & 5,551 & 6.6 & 6,772 & 6.8 & 6.595 & 6.7 & 6,714 & 7.4 & 6,914 & $7 .$. & $6.05 \equiv$ & 7.6 & 8,218 & 7.5 & 7,811 & 7 \\
\hline $\begin{array}{l}\text { Ordnance and } \\
\text { other mill litary }\end{array}$ & 177 & 0.2 & 204 & 0.2 & 207 & 0.2 & 193 & 0.2 & 219 & 0.2 & 405 & 0.5 & 654 & 0.6 & 918 & 0.8 \\
\hline $\begin{array}{l}\text { Export (reporting } \\
\text { companies only) }\end{array}$ & 2,595 & 3.1 & 2,007 & 2 & 1,224 & 1.3 & 1,076 & 1.2 & 1,839 & $2 . \overline{5}$ & 1.755 & 2.2 & 3,961 & 3.6 & 3,138 & 2.8 \\
\hline $\begin{array}{l}\text { Nonclassified } \\
\text { shipments }\end{array}$ & 7,820 & 9.3 & 9,041 & 9 & 7,864 & 8 & 6,616 & 7.3 & 5,928 & $6 . \epsilon$ & 5.537 & 6.9 & 6,963 & 6.3 & 7,105 & 6.4 \\
\hline Total shipments & 83,853 & 100 & 100,262 & 100 & 97,935 & 100 & 91,147 & 100 & 89,447 & 100 & 79.957 & 100 & 109,472 & 100 & 111,430 & 100 \\
\hline
\end{tabular}

${ }^{a}$ Net shipments eliminate tonnage duplication by deduct1ng from the gross total those shipments from cne reporting company to another for conversion, further processing, or resale.

Source: Ref. 1. 


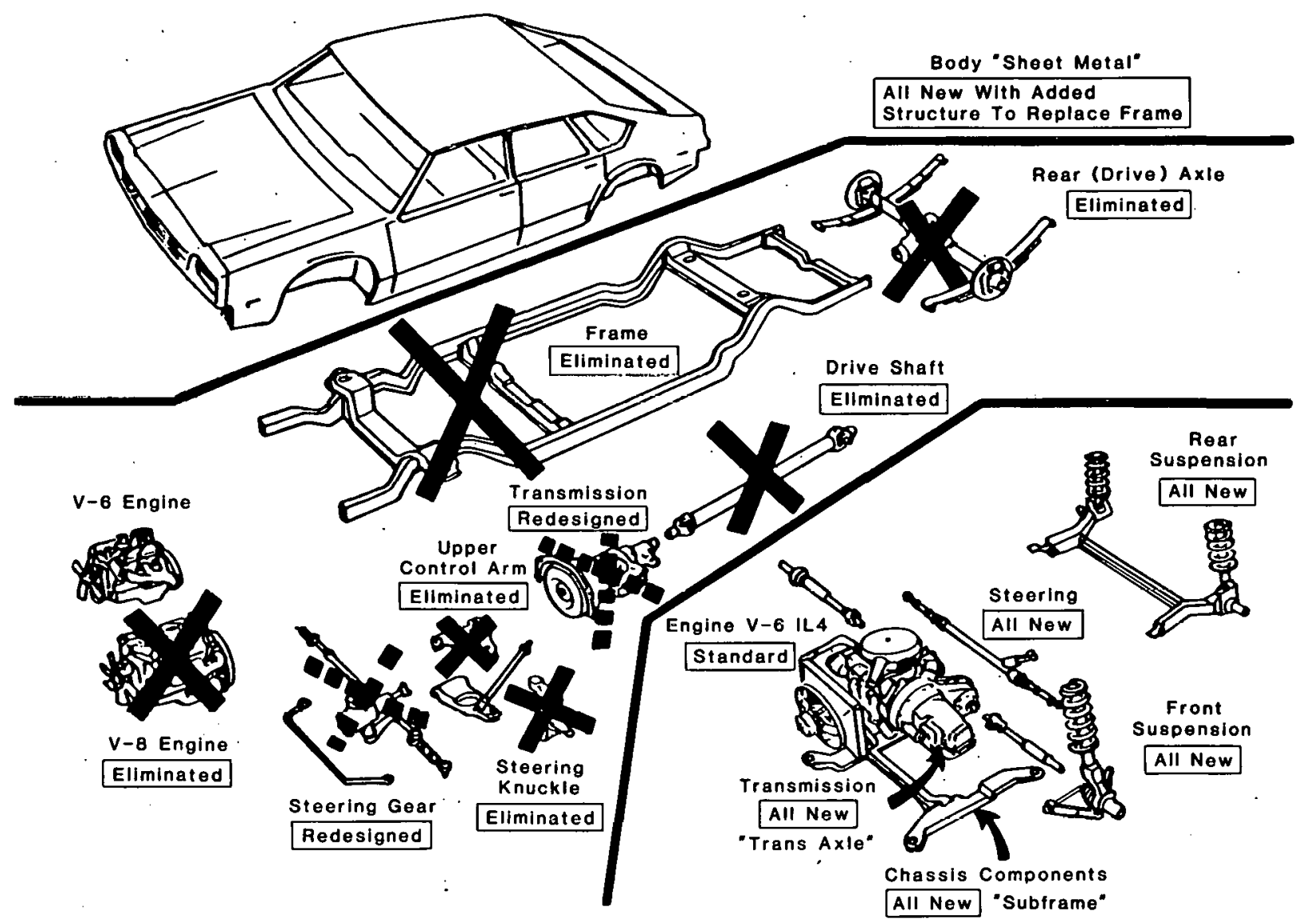

Fig. 1.1 Change to Front-Wheel Drive (Source: Ref. 5)

experimental car whose body structure weight was reduced by $48 \%$ by substituting graphite-reinforced plastic (GRP) for steel. The cost would have been prohibitively expensive, since GRP costs $\$ 20 / 1 \mathrm{~b}$, one order of magnitude more expensive than its substitutes.

Such substitutions, along with compacted graphite for cast-iron exhaust manifolds and aluminum for cast-iron intake manifolds and blocks, are expected to decrease the amount of steel per car by $5001 \mathrm{~b}$ by 1987.6 Other studies predict even greater reductions. ${ }^{7}$ These reductions, when coupled with the decrease that has already occurred in steel sales to the automobile industry -- from 18 million tons in 1974 to 12 million tons in 1980 (both relatively poor years for auto sales) -- mean a major shift in the pattern of steel sales that may well be permanent, although increased use of various high-strength steels (dual-phase steels in particular) may partially offset this trend.

The life-cycle energy use implications of the competition among coldrolled low-carbon steel, aluminum, and FRPs have been investigated in several recent studies. ${ }^{4,8}$ The Cummings-Saxton report ${ }^{4}$ calculated the impact of substituting equivalent structural amounts of FRP and aluminum for one pound 
of a low-carbon steel. The change in embodied energy in the material (reduced for FRP, increased for aluminum), plus the reduction in transportation energy caused by the weight reduction ( $0.4 \mathrm{lb}$ for FRP and $0.25 \mathrm{lb}$ for aluminum), reduced lifetime energy use by $85 \times 10^{3} \mathrm{Btu}$, in the case of FRP, and $37 \times 10^{3}$ Btu in the case of aluminum. However, the substitution of high-strength lowalloy (HSLA) steel for low-carbon steel reduced lifetime energy consumption by $42 \times 10^{3}$ Btu per pound of low-carbon steel replaced.

The A.D. Little study, ${ }^{8}$ with one important exception, reaches a similar conclusion. This study concludes that:

- "For most cases, plastics ... show lower life cycle energy use than rarhnn (or HST.A) steel:"

- "In many instances, sheet products made from either a luminum or carbon (or HSLA) stool show about equivalent life cycle energy use."

The only difference in the conclusions of the two reports relates to the comparison of aluminum with HSLA and the low-carbon steels. The A.D. Little report concludes that the three are about equivalent, while CummingsSaxton concludes that both aluminum and HSLA steel have a significant advantage over the low-carbon steels presently used.

The two studies used simflar 100,000-mile vehicle lifetimes, approximately the same energy savings per pound of weight reduction, and approximately the same embodied energy for aluminum and steel. Therefore, the difference in the conclusions can most likely be traced to (a) differences in the energy embodied in plastics (24.4 $\times 10^{3}$ Btu/lb for Cummings-Saxton; a range of $27-47 \times 10^{3} \mathrm{Btu} / 1 \mathrm{~b}$ for A.D. Little), and (b) differences in the weight replacement ratios assumed.

The possibility of substituting wood girders for steel in small structures has been investigated by the Committee on Renewable Resources for Industrial Materials of the National Research Council (NRC). The study concludes that, while manpower and capital requirements are about the same, energy requirements are cut $90 \%$ by such a substitution. 9 These results were substantiated in a recent University of Illinols study.10 However, the substitution of steel for wooden floor joints, studding, purlins, etc., for added strength and durability may offset the use of wood in home frames.

The industrial markets for steel are also feeling a pinch. A war between adhesives and fasteners is being waged in the fastener market, 11 while plastic gears have been moved out of the toy market into large (8-10 ft in diameter) industrial gear applications. They are cheap since they can be formed by injection molding, are light, and need no lubrication; their major problem is low load capacity above $250^{\circ} \mathrm{F} .12$ At the high-temperature end of the market, ceramic recuperators are being substituted for the superalloys (chromfum, cobalt, tungsten) to deal with temperatures in excess of $2500^{\circ} \mathrm{F}$, 
which are now routinely encountered in the recovery of very high temperature waste heat from melting processes. The U.S. Department of Energy (DOE) has a major research and development program in high-temperature ceramics, which should advance the introduction of these new products. Also, plastic pumps are replacing steel pumps in highly corrosive environments. 13

Finally, graphite or boron fibers in aluminum or magnesium matrices for structures, graphite fibers in copper matrices for bearings, silicon carbide fibers in aluminum or titanium matrices for high-temperature structural applications, and graphite aluminum for light-weight applications all show signs of entering markets previously dominated by steel and its alloys. 14

In almost every area, steel products are facing increasing competition from new materials; the only sectors where steel appears to have no major substitutes are agriculture and mining. With the continued increase in steel costs, the gradual reduction in steel consumption per $\$ 1,000$ of real GNP -from 0.12 ton in 1950 to 0.08 ton in $1977_{--}$is expected to continue. 6 
2 THE IRON AND STEEL INDUSTRY

\subsection{IRON AND STEEL STATISTICS}

Figure 2.1 illustrates the major steps in making iron and steel. Iron ore containing 25-35\% iron, mined principally in the upper Great Lakes region, is crushed, screened, and concentrated by gravity, flotation, or magnetic methods to yield a product containing $60-68 \%$ iron. Most of the ore now processed is either lumped and heat-hardened in a pelletizing process prior to shipment, or sent untreated to a sintering plant at the steel mill where it is agglomerated into hard masses in combination with steel-mill scale and metallics from slag and coke breeze. 'Ihen, it joins imported ores ( $3 U-35 \%$ ot total shipments) for further processing.

The ore is then mixed with colec and limeotone flux in a reducing environment -- the blast furnace. There, the oxygen in the ore combines with the carbon or carbon monoxide and is removed from the ore, along with various impurities taken out in the slag. Pig iron, the result of this process, contains too much carbon ( $4 \%$ ) for most uses and is removed in the steelmaking process; it is then mixed with scrap to produce various steel alloys. Hot rolling of the ingot follows, yielding steel slabs, billets, or blooms, which are then sent to the finishing mills for further treatment and conversion into the products listed in Table 1.3. Increasingly, slabs, billets, and blooms are being continuously cast, bypassing the ingot step.

Direct reduction of iron ores, a process that bypasses the blast furnace entirely, produces sponge iron by reduction at below-melting temperatures. It is of only minor importance now, but may grow in the future.

Table 2.1 shows the pattern of world iron and steel production over the last two decades. While world production has been fitfully increasing, the U.S. share has declined from over $35 \%$ in the mid-1950s to on $1 y 14.1 \%$ in 1980 , a drop paralleled by the emergence of Japan as a major steelmaking country in the free world. The trend of steel imports and exports is shown in Table 2.2, and recent steel price trends are given in Table 2.3. Estimates of total domestic investment in iron and steel plants and equipment are given in Table 2.4. The profitability of the industry, as measured by the real, (1.e., deflated) rate of return on investment, was estimated to be $10 \%$ in 1949-1954, but dropped to $-1 \%$ in 1975-1978, according to the office of Technology Assessment. (OTA) 6 Figure 2.2 shows estimates of the real rates of return and inflation for 1949-1978.

According to the American Iron and Steel Institute (AISI), the total direct energy consumed in the production of iron and steel was estimated to be $2.27 \times 10^{15}$ Btu in 1980 (see Table 3.2). Of this total, AISI estimates that $64 \%$ was derived from coal, $5 \%$ from fue 1 o1 1 ; $24 \%$ from natural gas, and $6 \%$ from electricity (see Table 3.3). Blast furnaces consumed $100 \%$ of the coke, $33 \%$ of the fuel oil, and. $9 \%$ of the natural gas. 

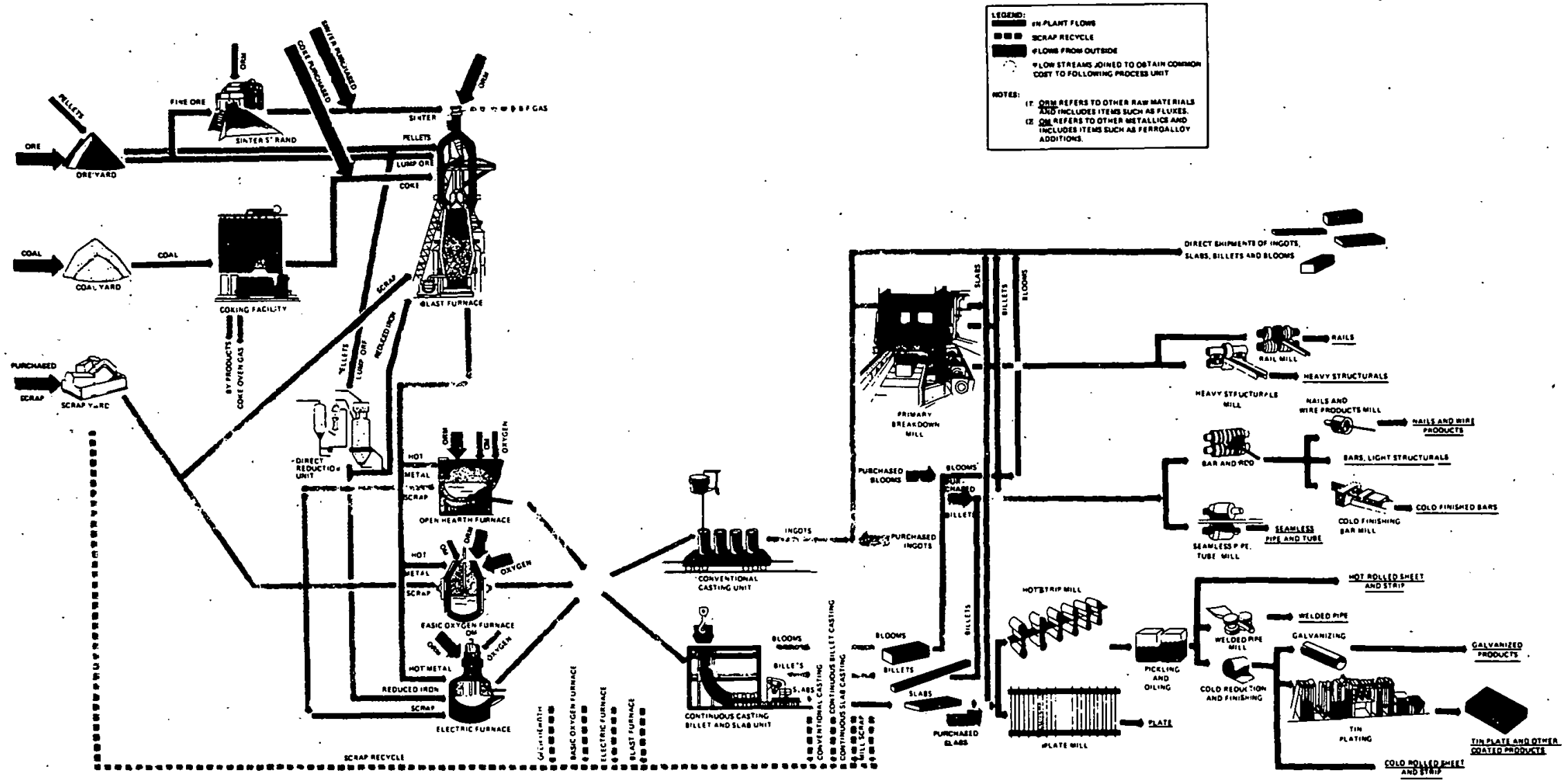

F1g. 2.1 Process Unit Interrelationships for Ironmaking, Steelmaking, and Steel Forming (Source: Ref. 15) 
Table 2.1 World Raw Steel Production, 1956-1980

\begin{tabular}{|c|c|c|c|c|c|}
\hline \multirow[b]{2}{*}{ Year } & \multicolumn{4}{|c|}{ Production ( $10^{6}$ tons) } & \multirow{2}{*}{$\begin{array}{c}\text { U.S. Share } \\
\text { of Total } \\
(\%)\end{array}$} \\
\hline & World & $\begin{array}{l}\text { Common } \\
\text { Market }\end{array}$ & Japan & $\begin{array}{l}\text { United } \\
\text { States }\end{array}$ & \\
\hline 1956 & 283.8 & 77.9 & 12 & 104.5 & 36.8 \\
\hline 1957 & 291.8 & 82 & 12.5 & 102.2 & 35 \\
\hline 1958 & 270.9 & 78 & 12.1 & 77.4 & 28.5 \\
\hline 1959 & 305.8 & 84 & 16.6 & 84.7 & 27.7 \\
\hline $\begin{array}{l}1960 \\
1961\end{array}$ & $\begin{array}{l}346.1 \\
353.8\end{array}$ & $\begin{array}{l}97.9 \\
96.1\end{array}$ & $\begin{array}{l}22.1 \\
28.3\end{array}$ & $\begin{array}{l}90.1 \\
88.9\end{array}$ & $\begin{array}{l}26 \\
25.1\end{array}$ \\
\hline 1962 & 357.4 & 94 & 27.6 & 89.2 & 24.9 \\
\hline 1963 & 382.9 & 96.5 & 31.5 & y9.1 & 25.4 \\
\hline 1964 & 434.5 & 109.9 & 39.8 & 115.3 & 26.5 \\
\hline 1965 & 456.3 & 113.8 & 41.2 & 119.3 & 26.1 \\
\hline 1966 & 470.8 & 110.2 & 47.8 & 121.6 & 25.8 \\
\hline 1967 & 496.7 & 114.5 & 62.1 & 115.4 & 23.2 \\
\hline 1968 & 528.3 & 125.3 & 66.8 & 119.3 & 22.6 \\
\hline 1969 & 573.2 & 134.7 & 82.1 & 128.2 & 22.4 \\
\hline 1970 & 593.4 & 137.5 & 93.3 & 119.3 & 20.1 \\
\hline 1971 & 580.4 & 128.2 & 88.5 & 109.2 & 18.8 \\
\hline 1972 & 629.9 & 126.2 & 96.9 & 120.8 & 19.2 \\
\hline 1973 & 697.1 & 150.1 & 108.2 & 136.8 & 19.6 \\
\hline 1974 & 710 & 155.5 & 117.1 & 132.1 & 18.6 \\
\hline 1975 & 645.8 & 125.3 & 102.3 & 105.8 & 16.4 \\
\hline 1976 & 683.1 & 134.3 & 107.4 & 116.1 & 17 \\
\hline 1977 & 673.9 & 125.3 & 102.4 & 113.1 & 16.7 \\
\hline 1978 & 711.7 & 133.1 & 102.1 & 124.3 & 17.5 \\
\hline 1979 & 824 & 154 & 123 & 136 & 16.5 \\
\hline 1980 & 741 & 140 & 123 & 111 & 14.1 \\
\hline
\end{tabular}

Source: Ref. 6 for 1956-1978 data; Ref. 1 for 1979-1980 data.

There is some disagreement about the data and definitions used to calculate direct and indirect energy use. Table 3.4 in Sec: 3 calculates the amounts for 1980 in a slightly unconventional way, by focusing on total domestic energy use (e.g., assuming zero energy use for imports) and assigning only the heating value of coke $\left(25.99 \times 10^{6} \mathrm{Btu} / \mathrm{ton}\right)$ to the blast furnace. The direct energy associated with the major raw materials purchased by the industry therefore amounted to $2.38 \times 10^{15} \mathrm{Btu}$ in 1980 , and total energy use amounted to $2.96 \times 10^{15} \mathrm{Btu}$. Thus, indirect energy use amounted to about $20 \%$ of direct energy use. If the full inverse input/output ( $I / 0)$ treatment were applied to the industry, the percentage would be higher. 
Table 2.2 U.S. Imports and Exports of Steel Mill Products, 1956-1980

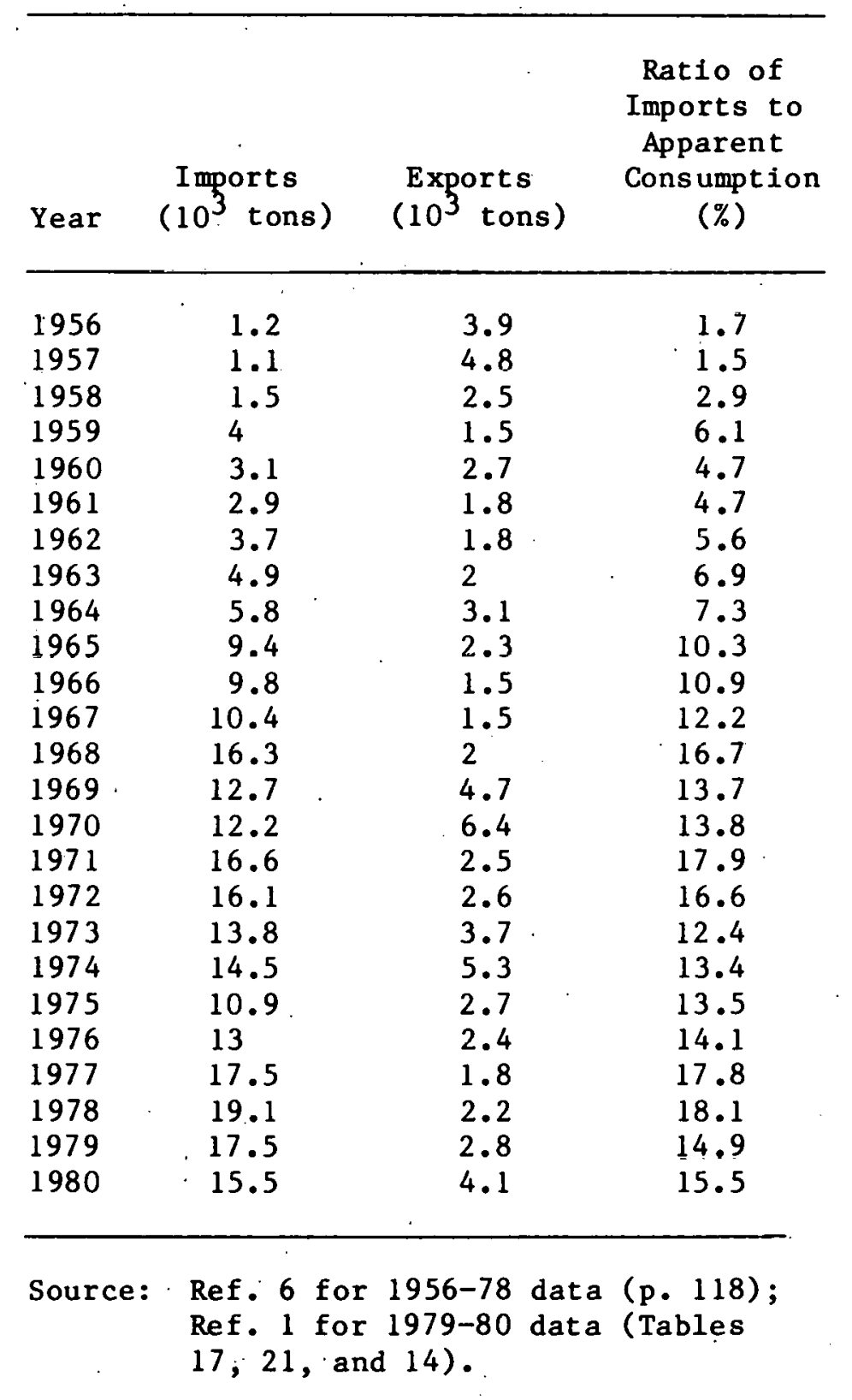

\subsection{INDUSTRY STRUCTURE}

In 1980; over $90 \%$ of domestic iron ore was mined in the upper Great Lakes region, with southern $(3 \%)$ and western $(7 \%)$ ores making up the remainder. 16 The proximity of coal, cheap water, and rail transportation for the iron ores led the integrated iron and steel industry to develop along the shores of the Great Lakes. Over $80 \%$ of the integrated mills, and almost $70 \%$ of the semi-integrated and specialty steel plants, are located in states 
Table 2.3 Index of Steel Industry Prices and Costs, 1965-1978

(1967 base year except as noted)

\begin{tabular}{|c|c|c|c|c|c|c|c|c|c|}
\hline \multirow[b]{2}{*}{ Year } & \multirow{2}{*}{$\begin{array}{l}\text { Consumer } \\
\text { Price } \\
\text { Index }\end{array}$} & \multicolumn{7}{|c|}{ Producer Price Indexes } & $\cdot$ \\
\hline & & $\begin{array}{l}\text { Industrial } \\
\text { Commodities }\end{array}$ & $\begin{array}{l}\text { Steel Mill } \\
\text { Products }\end{array}$ & $\begin{array}{l}\text { Metal- } \\
\text { lurgiçal } \\
\text { Coal }^{2}\end{array}$ & $\begin{array}{l}\text { Iron Ore }{ }^{c} \\
\text { (pellets) }\end{array}$ & $\begin{array}{l}\text { Steel } \\
\text { Scrap }\end{array}$ & $\begin{array}{c}\text { Electrical } \\
\text { Power }\end{array}$ & $\begin{array}{l}\text { Fue1 } \\
\text { O11 }\end{array}$ & Wages $^{d}$ \\
\hline 1965 & 94.5 & 96.4 & 97.5 & 96.8 & NA & 112.6 & 103 & 107.7 & 94.05 \\
\hline 1966 & 97.2 & 98.6 & 98.9 & 98.4 & NA & 106.6 & 99.8 & 105 & 97.37 \\
\hline 1967 & 100 & 100 & 100 & 100 & NA & 100 & 100 & 100 & 100 \\
\hline 1968 & 104.2 & 102.5 & 102.5 & 101.8 & NA & 93 & 100.9 & 95.7 & 105.76 \\
\hline 1969 & 109.8 & 106 & 107.4 & 110.2 & 100 & 110.8 & 102.2 & 93.3 & 112.97 \\
\hline 1970 & 116.3 & 110 & 114.3 & 150.9 & 105.1 & 138.8 & 106.6 & 125.5 & 119.31 \\
\hline 1971 & 121.3 & 113.9 & 123 & 185.3 & 111.1 & 114.6 & 115.5 & 166 & 131.59 \\
\hline 1972 & 125.3 & 117.9 & 130.4 & 198.4 & 111.1 & 121.8 & 123.9 & $158.8^{\circ}$ & 148.7 \\
\hline 1973 & 133.1 & 127 & 134.1 & 216.5 & 116.4 & 188 & 132.6 & 190.4 & 161.43 \\
\hline 1974 & 147.7 & 153.8 & 170 & 232.8 & 140.3 & 353.2 & 172.3 & 485.4 & 190.79 \\
\hline 1975 & 161.2 & 171.5 & 197.2 & 622.1 & 181.2 & 245.6 & 193.2 & 495.5 & 222.57 \\
\hline $1976^{\circ}$ & 170.5 & 182.5 & 209.7 & 657.8 & 201.6 & 259 & 226.9 & 451.7 & 246.82 \\
\hline 1977 & 181.6 & 195.1 & 229.9 & 671.3 & 220.2 & 233.7 & 257.2 & 521.4 & 273.76 \\
\hline 1978 & 195.4 & 209.3 & 254.5 & 704.9 & 230.1 & 278.2 & 279.7 & 496.8 & 300.36 \\
\hline
\end{tabular}

$a_{\text {Wholesale price index. }}$

$b_{\text {High-volume. }}$

C December 1969 base.

dincluding fringe benefits.

$\mathrm{NA}=$ not available.

Source: Ref. 6, p. 122 . 
Table 2.4 Selected Financial Data for the U.S. Steel Industry, 1970-1978

\begin{tabular}{|c|c|c|c|c|c|c|c|}
\hline \multirow[b]{2}{*}{ Year } & \multirow[b]{2}{*}{$\begin{array}{l}\text { Profits } \\
\text { after Taxes } \\
\left(\$ 10^{6}\right)\end{array}$} & \multirow{2}{*}{$\begin{array}{l}\text { Deprectation, } \\
\text { Depletion } \\
\text { Etc. }{ }^{6}\left(\$ 10^{6}\right)\end{array}$} & \multirow[b]{2}{*}{$\begin{array}{c}\text { Gross } \\
\text { Cash Flow } \\
\left(\$ 10^{6}\right)\end{array}$} & \multicolumn{2}{|c|}{ Cash Dividends } & \multirow[b]{2}{*}{$\begin{array}{c}\text { Net } \\
\text { Cash Flow } \\
\left(\$ 10^{6}\right)\end{array}$} & \multirow[b]{2}{*}{$\begin{array}{c}\text { Capital } \\
\text { Expenditures } \\
\cdot\left(\$ 10^{6}\right)\end{array}$} \\
\hline & & & & $\begin{array}{r}\text { Total } \\
\left(\$ 10^{6}\right)\end{array}$ & $\begin{array}{l}\text { As \% of } \\
\text { After-Tax } \\
\text { Credits }\end{array}$ & & \\
\hline $\begin{array}{l}1970 \\
1971 \\
1972 \\
1973 \\
1974 . \\
1975 \\
1976 \\
1977 \\
1978\end{array}$ & $\begin{array}{r}532 \\
563 \\
775 \\
1,272 \\
2,475 \\
1,595 \\
1,337 \\
22 \\
1,292\end{array}$ & $\begin{array}{r}1,128 \\
1,123 \\
1,196 \\
1,329 \\
1,553 \\
1,591 \\
1,614 \\
1,888 \\
2,010\end{array}$ & $\begin{array}{l}1,660 \\
1,686 \\
1,971 \\
2,601 \\
4,028 \\
3,186 \\
2,951 \\
1,910 \\
3,302\end{array}$ & $\begin{array}{l}488 \\
390 \\
402 \\
443 \\
675 \\
658 \\
637 \\
555 \\
533\end{array}$ & $\begin{array}{c}91.7 \\
69.3 \\
51.9 \\
34.8 \\
27.2 \\
41.5 \\
47.6 \\
\text { b } \\
41.3\end{array}$ & $\begin{array}{l}1,172 \\
1,296 \\
1,569 \\
2,158 \\
3,354 \\
2,528 \\
2,314 \\
1,355 \\
2,769\end{array}$ & $\begin{array}{l}1,736 \\
1,425 \\
1,174 \\
1,400 \\
2,115 \\
3,179 \\
3,253 \\
2,850 \\
2,538\end{array}$ \\
\hline
\end{tabular}

ancludes changes in reserves.

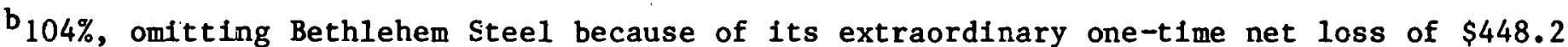
million. Bethlehem's dividends represented $14.6 \%$ ( $\$ 65.5 \mathrm{mllli}$ ion) of that net loss.

Source: $\operatorname{Ref} .6$, p. 121 . 
A. Rates of return and inflation

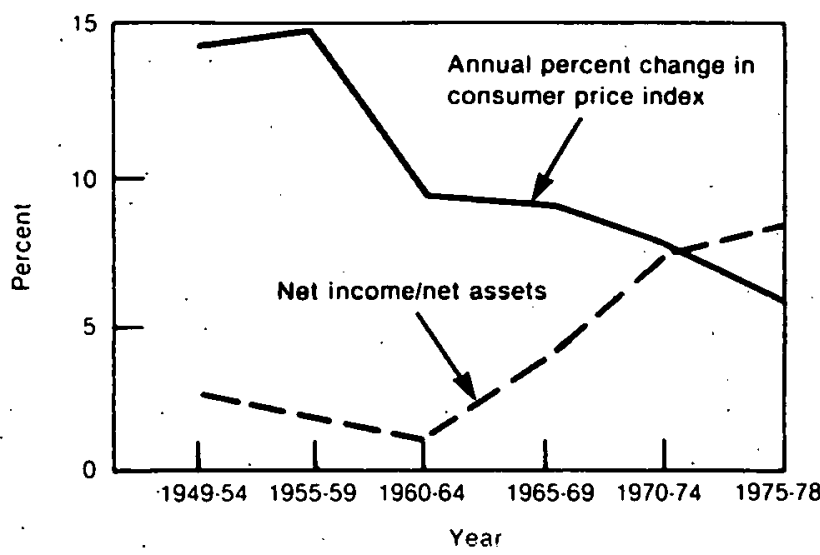

B. Real rates of return

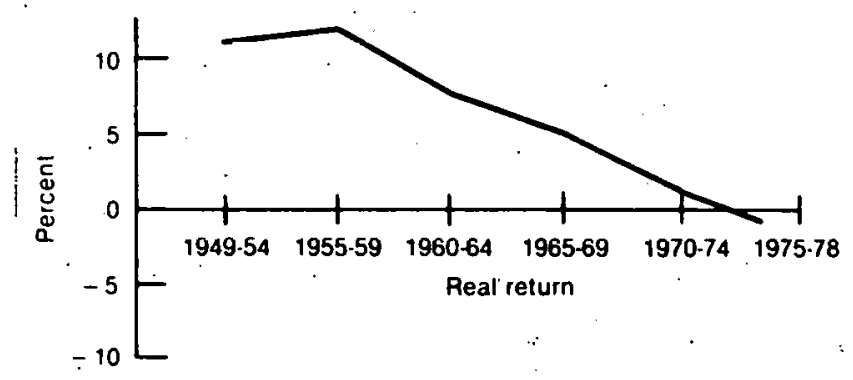

Fig. 2.2 Annual Average Rates of Return and Inflation in the Steel Industry, 1949-1978 (Source: Ref. 6)

bordering the Great Lakes -- New York, Pennsylvania, Ohio, Indiana, Illinois, and Michigan. 17. The nonintegrated mills -- those producing steel from scrap or, to a very minor extent, directly reduced iron -- are located near the large metropolitan centers that are the source of their raw material. Figure 2.3 shows the geographic distribution of iron ore mines, coke ovens, and both the integrated and nonintegrated steel producers.

In 1980, total raw steel production was approximately 111 million tons, involving 178 blast furnaces and around 700 steel furnaces. 1 of this amount, $60 \%$ was from basic oxygen furnaces (BOFs), $12 \%$ from open hearths, and $28 \%$ from electric arcs. The BOF percentage share is leveling out after a steady rise since 1960; open hearths are being phased out, and the share of electric arcs is increasing (see Table 10.1). However, if the steel markets recover, the BOF share can be expected to again increase.

The industry's hot metal/scrap ratio (scrap defined here to mean home, promt, and obsolete scrap) was virtually constant at 1.25 for many years.' In 1977 , it began to slide, reaching 1.00 in 1980 -- indicating that the source of iron was split equally between scrap and ore. 1 Further, the focus of scrap recycling has shifted from integrated mills, where electric arc and open hearth furnaces are used together to melt scrap, to electric arc furnaces in "cold," or all-scrap, mini-mills. Since some scrap is "mined" from the nation's obsolete-scrap stockpile, there are absolute limits on how small the ratio can get, depending on primary steel production growth rates, product lifetimes, and limits on the fraction of the original volume of material capable of being recycled due to rust, dispersion, etc. As explained in Sec. 9, the rising cost of collecting the increasing fraction of obsolete scrap will cause the ratio to bottom out well before it encounters any such absolute limit. 


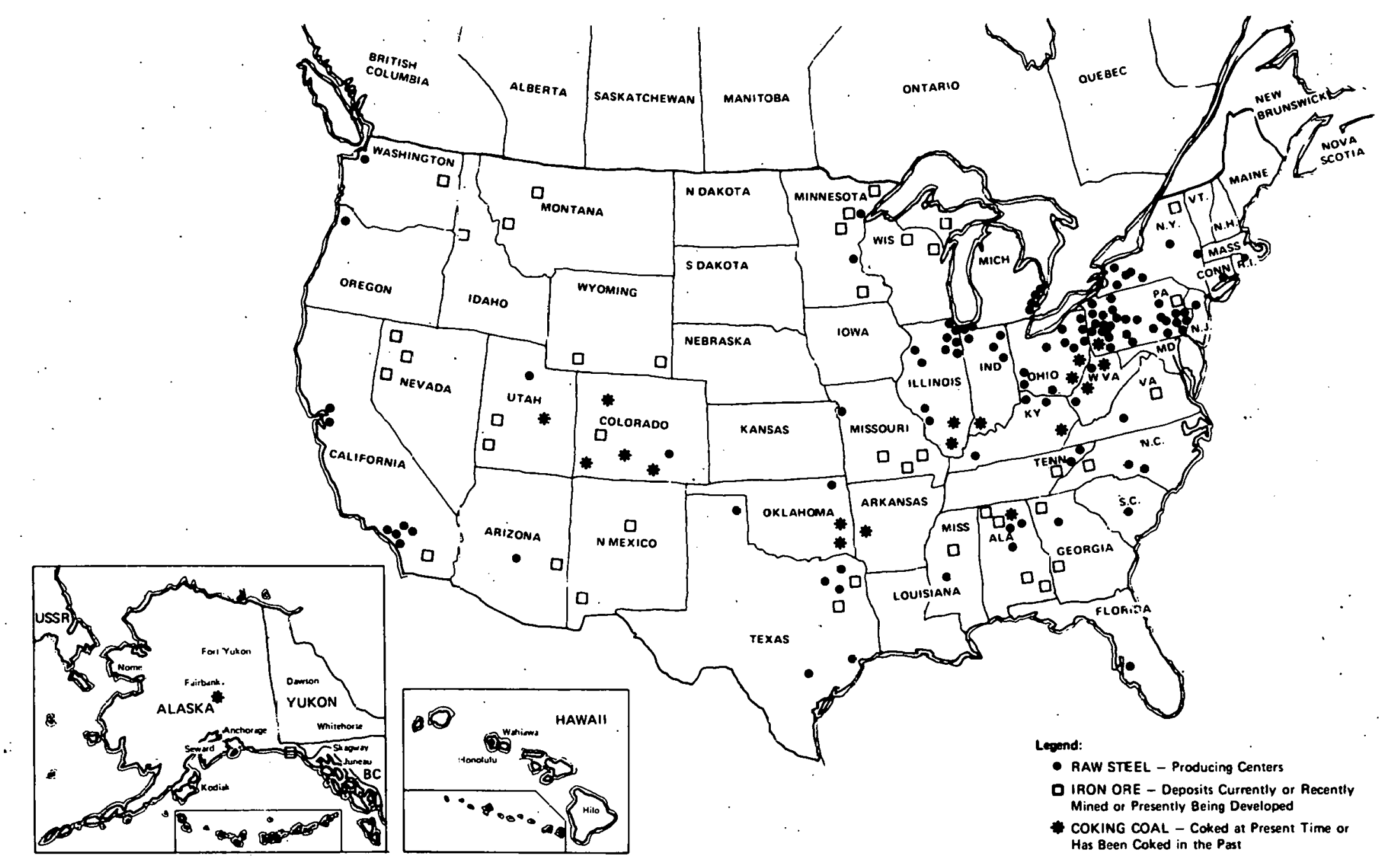

Fig. 2.3 Geographical Distribution of the U.S. Iron and Steel Industry (Source: Ref. 18) 
The mini-mill industry segment is still small -- accounting for $13 \%$ of total shipments in 1978. But its output tripled in the last decade, while the market of integrated mills continued to contract. The OTA study explains some of the reasons for this shift towards the "mini-mills," as they are termed: 6

- They use sophisticated continuous-casting, direct-rolling, electric furnace practices and advanced scrap-handling techniques.

- Construction costs and lead times are low, and small plants that are competitive for a limited range of products can be built.

- The stockpile of their raw material, scrap, is growing, while iron ore, the major raw material of the integrated mills, is getting srarcer. Arcoriting to a rerent repnrt, "net additions were made to the inventory of obsolete ferrous scrap during 19 of the 20 years between 1956 and 1975."19 (Others disagree and predict a scrap shortage in the $1980 \mathrm{~s}^{20}$ )

- Their product markets, primarily simple products such as reinforcing bars and merchant steel, have maintained their volume while other segments -- in particular, flat products -- have slipped.

These trends are expected to continue in the 1980s, when the mini-mills will likely provide more than $25 \%$ of the market. 6

Table 2.5 summarizes various statistics for the industry in $19 / /$, while Table 2.6 gives historical statistics for earlier years. Table 2.7 gives the tonnages shipped and returns on investment for the top 27 companies in 1977 and 1978. Total steel shlpments in 1978 were 98 million tons. ${ }^{\text {P }}$ The top four firms accounted for over $45 \%$ of total shipments, while the top 10 accounted for almost 70\%. These market shares are nearly the same as in 1973. 
Table 2.5 Summary Statistics for Blast Furnaces and Steel Mills (SIC 3312), 1977

\begin{tabular}{|c|c|c|c|c|c|}
\hline \multirow[b]{2}{*}{ Item } & \multirow[b]{2}{*}{$\begin{array}{c}\text { Fully } \\
\text { Integrated } \\
\text { (SIC 3312-11) }\end{array}$} & \multicolumn{2}{|c|}{ Partially Integrated } & \multirow[b]{2}{*}{$\begin{array}{l}\text { Nonintegrated } \\
\text { (SIC 3312-14) }\end{array}$} & \multirow[b]{2}{*}{ Total } \\
\hline & & $\begin{array}{l}\text { With Blast } \\
\text { Furnaces } \\
\text { (SIC } 3312-12 \text { ) }\end{array}$ & $\begin{array}{l}\text { Without Blast } \\
\text { Furnaces } \\
\text { (SIC 3312-13) }\end{array}$ & & \\
\hline \multirow{2}{*}{\multicolumn{2}{|c|}{ Number of establishments }} & & & & \\
\hline & - & - & - & 254 & 254 \\
\hline $20-99$ employees & - & - & 1 & 44 & 45 \\
\hline 100 employees or more & 35 & 17 & 81 & 72 & 205 \\
\hline Total & 35 & 17 & 82 & 370 & 504 \\
\hline \multicolumn{2}{|l|}{ Aggregate emp loyee data } & & & & \\
\hline $\begin{array}{l}\text { Total number }\left(10^{3}\right) \\
\text { Payrall }\left(\$ 10^{6}\right)\end{array}$ & $\begin{array}{r}240.8 \\
4,888.3\end{array}$ & $\begin{array}{r}57.3 \\
1,100.7\end{array}$ & $\begin{array}{r}93.6 \\
1,800.9\end{array}$ & $\begin{array}{r}50.2 \\
935.8\end{array}$ & $\begin{array}{r}441.9 \\
8,725.7\end{array}$ \\
\hline \multicolumn{2}{|l|}{ Production workers ${ }_{2}$ only } & & & & \\
\hline Total number $\left(10^{3}\right)$ & 190 & 47.6 & 73 & 39.6 & $\begin{array}{l}350.2 \\
668.7\end{array}$ \\
\hline $\begin{array}{l}\text { Man-hours }\left(10^{\circ}\right) \\
\text { Wages }\left(\$ 10^{6}\right)\end{array}$ & $\begin{array}{r}360.9 \\
3,712.7\end{array}$ & $\begin{array}{r}90.2 \\
877.2\end{array}$ & $\begin{array}{r}141.7 \\
1.353 .2\end{array}$ & $\begin{array}{r}75.8 \\
710.1\end{array}$ & $\begin{array}{l}668.7 \\
6,653\end{array}$ \\
\hline Cost of materials $\left(\$ 10^{6}\right)$ & $12,919.2$ & $4,406.4$ & 5,049 & $4,340.3$ & 26,715 \\
\hline $\begin{array}{l}\text { Velue of shipments, } \\
\text { 1r.cluding resales }\left(\$ 10^{6}\right)\end{array}$ & $21,311.6$ & $6,742.1$ & $8,246.1$ & $5,698.5$ & $41,998.2$ \\
\hline $\begin{array}{l}\text { Value added by } \\
\text { manufacture }\left(\$ 10^{6}\right)\end{array}$ & $8,334.8$ & $2,415.6$ & $3,252.7$ & $1,328.9$ & $15,331.9$ \\
\hline $\begin{array}{l}\text { Capital expenditures for } \\
\text { plant and equipment }\left(\$ 10^{6}\right)\end{array}$ & $1,284.1$ & 105 & 462.6 & 375.8 & $2,227.5$ \\
\hline \multicolumn{2}{|l|}{$\begin{array}{l}\text { New gapital expenditures } \\
\left(\$ 10^{6}\right)\end{array}$} & & & & \\
\hline $\begin{array}{l}\text { New brildings and } \\
\text { other structures }\end{array}$ & 164.7 & 3.1 & 36.3 & 21.4 & 225.6 \\
\hline $\begin{array}{l}\text { New machinery and } \\
\text { equipment }\end{array}$ & $1,091.6$ & 100.9 & 419.5 & 305.5 & $1,917.6$ \\
\hline Total & $1,256.4^{a}$ & $104.1^{\mathrm{a}}$ & 455.8 & 326.9 & $2,143.1^{a}$ \\
\hline
\end{tabular}

${ }^{a}$ Doses not add up due to rounding.

Source: Adapted from Ref. 21. 
Table 2.6 Historical Statistics for SIC 3312 Blast Furnaces and Steel Mills, 1963-1977

\begin{tabular}{|c|c|c|c|c|c|c|c|c|c|c|c|c|c|}
\hline \multirow[b]{2}{*}{ Year } & \multirow[b]{2}{*}{$\begin{array}{l}\text { Number of } \\
\text { Establish- } \\
\text { ments }{ }^{2}\end{array}$} & \multicolumn{2}{|c|}{$\begin{array}{l}\text { Number of } \\
\text { Companies a }\end{array}$} & \multicolumn{2}{|c|}{$\begin{array}{c}\text { Aggregate } \\
\text { Employee Data } \\
\end{array}$} & \multicolumn{2}{|c|}{ Production Wor } & rs Only & \multirow{2}{*}{$\begin{array}{l}\text { Value } \\
\text { Added } \\
\text { by Manu- } \\
\text { facture } \\
\left(\$ 10^{6}\right)\end{array}$} & \multirow[b]{2}{*}{$\begin{array}{c}\text { Cost of } \\
\text { Mater }-q^{-}-s \\
\left(\$ 10^{\circ}\right.\end{array}$} & \multirow[b]{2}{*}{$\begin{array}{l}\text { Value of } \\
\text { Shipments } \\
\quad\left(\$ 10^{6}\right)\end{array}$} & \multirow[b]{2}{*}{$\begin{array}{c}\text { New Capital } \\
\text { Expenditures } \\
\left(\$ 10^{6}\right)\end{array}$} & \multirow{2}{*}{$\begin{array}{l}\text { Gross } \\
\text { Value } \\
\text { of Fixed } \\
\text { Assets } \\
\left(\$ 10^{6}\right)\end{array}$} \\
\hline & & Total & $\begin{array}{l}\text { W1th } 20 \\
\text { or More } \\
\text { Employees }\end{array}$ & $\begin{array}{l}\text { Total } \\
\text { Number } \\
\left(10^{3}\right)\end{array}$ & $\begin{array}{l}\text { Payrq11 } \\
\left(\$ 10^{6}\right)\end{array}$ & $\begin{array}{l}\text { Total } \\
\text { Number } \\
\left(10^{3}\right)\end{array}$ & $\begin{array}{l}\text { Man- } \\
\text { Hours } \\
\left(10^{6}\right)\end{array}$ & $\begin{array}{l}\text { Wagess } \\
\left(\$ 10^{6}\right)\end{array}$ & & & & & \\
\hline $\begin{array}{l}1977 \\
1976 \\
1975 \\
1974 \\
1973\end{array}$ & $\begin{array}{r}396 \\
\text { NA } \\
\text { NA } \\
\text { NA } \\
\text { NA }\end{array}$ & $\begin{array}{r}504 \\
\text { NA } \\
\text { NA } \\
\text { NA } \\
\text { NA }\end{array}$ & $\begin{array}{r}250 \\
\text { NA } \\
\text { NA } \\
\text { NA } \\
\text { NA }\end{array}$ & $\begin{array}{l}441.9 \\
451.9 \\
451.3 \\
518 \\
502.1\end{array}$ & $\begin{array}{l}8,725.7 \\
8,041.7 \\
7,076.4 \\
7,513.2 \\
6,480.9\end{array}$ & $\begin{array}{l}350.2 \\
358 \\
354.8 \\
412.3 \\
409.9\end{array}$ & $\begin{array}{l}668.7 \\
680.9 \\
657.7 \\
811.5 \\
822.8\end{array}$ & $\begin{array}{l}6,653 \\
6,100.7 \\
5,298.5 \\
5,848.8 \\
5,065.2\end{array}$ & $\begin{array}{l}15,331.9 \\
14,755.5 \\
13,356.2 \\
17,425.8 \\
17,769.4\end{array}$ & $\begin{array}{l}26,715 \\
25,665.9 \\
23,162.3 \\
24,34 \div .6 \\
17,382.5\end{array}$ & $\begin{array}{l}41,998.2 \\
39,684.1 \\
35,659.8 \\
41,671.7 \\
30,365.5\end{array}$ & $\begin{array}{l}2,143.1 \\
2,142.3 \\
2,068 \\
1,643.4 \\
1,110.5\end{array}$ & $\begin{array}{c}\text { NA } \\
32,645.8 \\
30,880.5 \\
29,395.6 \\
28,018.4\end{array}$ \\
\hline $\begin{array}{l}1972 \\
1971 \\
1970 \\
1969 \\
1968\end{array}$ & $\begin{array}{r}241 \\
\text { NA } \\
\text { NA } \\
\text { NA } \\
\text { NA }\end{array}$ & $\begin{array}{r}364 \\
\text { NA } \\
\text { NA } \\
\text { NA } \\
\text { NA }\end{array}$ & $\begin{array}{r}251 \\
\text { NA } \\
\text { NA } \\
\text { NA } \\
\text { NA }\end{array}$ & $\begin{array}{l}469.1 \\
482.2 \\
526.5 \\
537.7 \\
533.1\end{array}$ & $\begin{array}{l}5,537.8 \\
4,968.9 \\
5,060.3 \\
5,092.9 \\
4,719.7\end{array}$ & $\begin{array}{l}379.3 \\
385 \\
424.7 \\
436.4 \\
43.2 .9\end{array}$ & $\begin{array}{l}739.1 \\
737.9 \\
822.5 \\
872.5 \\
856.7\end{array}$ & $\begin{array}{l}4,254.3 \\
3,743.8 \\
3,854.6 \\
3,925.5 \\
3,628.9\end{array}$ & $\begin{array}{r}10,304.7 \\
9,563.1 \\
9,350.5 \\
9,853.2 \\
9,275.8\end{array}$ & $\begin{array}{l}14,022.6 \\
12,263.7 \\
12,381.3 \\
12,681 . ? \\
11,679.5\end{array}$ & $\begin{array}{l}23,946.7 \\
21,971.3 \\
21,501.6 \\
22,299 \\
21,161.1\end{array}$ & $\begin{array}{r}961.2 \\
1,005.4 \\
1,329.9 \\
1,574.5 \\
1,794.7\end{array}$ & $\begin{array}{l}27,083.3 \\
26,486.7 \\
25,850.4 \\
24,707.1 \\
22,654.5\end{array}$ \\
\hline $\begin{array}{l}1967 \\
1966 \\
1965 \\
1964 \\
1963\end{array}$ & $\begin{array}{r}200 \\
\text { NA } \\
\text { NA } \\
\text { NA } \\
161\end{array}$ & $\begin{array}{r}329 \\
\text { NA } \\
\text { NA } \\
\text { NA } \\
288\end{array}$ & $\begin{array}{r}259 \\
\text { NA } \\
\text { NA } \\
\text { NA } \\
247\end{array}$ & $\begin{array}{l}533.1 \\
559.4 \\
565.4 \\
532.9 \\
500.6\end{array}$ & $\begin{array}{l}4,385.3 \\
4,540.7 \\
4,431.6 \\
4,117.9 \\
3,711.6\end{array}$ & $\begin{array}{l}434 \\
460.4 \\
464.5 \\
443.9 \\
412.3\end{array}$ & $\begin{array}{l}845.4 \\
904.9 \\
912.9 \\
880.9 \\
791.4\end{array}$ & $\begin{array}{l}3,368.4 \\
3,554.1 \\
3,498.5 \\
3,249.7 \\
2,892.0\end{array}$ & $\begin{array}{l}8,910.1 \\
9,643.7 \\
9,379.9 . \\
8,479.6 \\
7,506.4\end{array}$ & $\begin{array}{r}10,997.9 \\
11,829.5 \\
11,387.3 \\
10,537.9 \\
8,95.3 .7\end{array}$ & $\begin{array}{l}19,620.6 \\
21,193.9 \\
20,841.7 \\
18,840.1 \\
16,418\end{array}$ & $\begin{array}{l}1,661 \\
1,595.9 \\
1,364 \\
1,282.9 \\
908.4\end{array}$ & $\begin{array}{c}21,524.5 \\
\text { NA } \\
\text { NA } \\
17,720.4 \\
16,604\end{array}$ \\
\hline
\end{tabular}

${ }^{a}$ The relationship of establishments to companies is as follows: a company is a business organizetion soneisting of one establishment or more under common ownership or control.

NA $=$ not avallable.

Source: Adapted from Bef. 21 . 
Table 2.7 Steel Company Profitability by

Industry Segment, 1977-1978

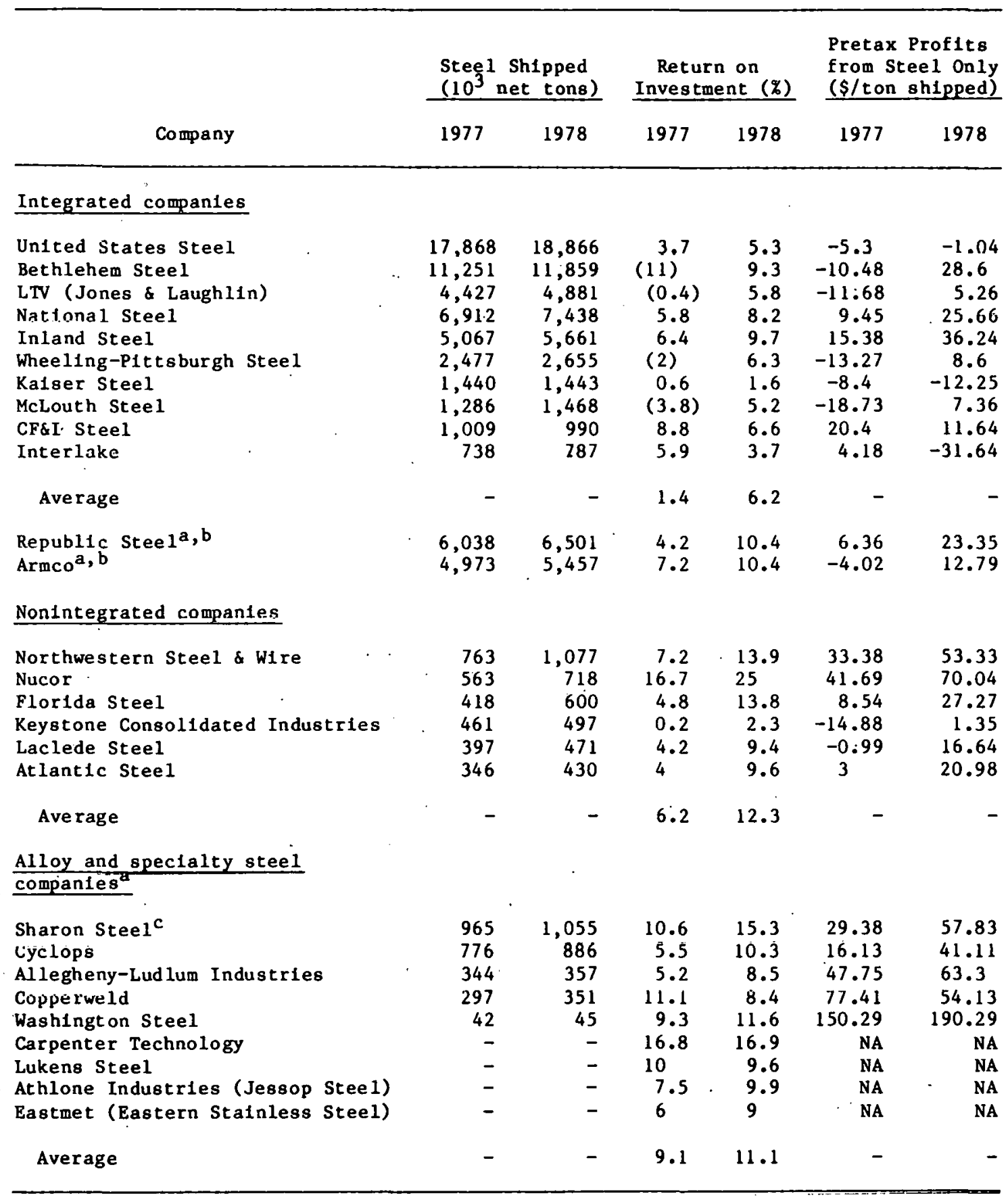

${ }^{a}$ Alloys and specialty steels are over $10 \%$ of company steel shipments.

because of the substantial alloy and specialty steel business, the investment returns are not averaged together wth those of the other integrated companies $118 \mathrm{~s}$.

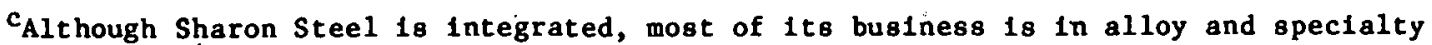
steels.

Source: Ref. 6, p. 122 . 
3 MATERIALS AND ENERGY FLOWS OVERVIEW

\subsection{DATA SOURCES}

Energy use and materials flow data for the fron and steel industry can be obtained from several sources (see Table 3.1). The Census of Manufactures' five-year censuses are the most complete source of information. The Bureau of the Census also collects and publishes yearly data (in its Annual Survey of Manufacturers) on fuels, materials flows, and electricity purchased by Standard Industrial Classification (SIC) 3312 blast furnaces and steel mills, but does not routinely do so for coal, coke, and the various by-products associated with coke, which generally amount to over one-half of the industries' true direct consumption of energy. However, a special report issued in December 1980 does include coke and coal input data. 22

DOE collects and publishes data on coke and coal chemicals, including what is consumed by the iron and steel industry. The Bureau of Mines and the Bureau of the Census both collect information on SIC 1011 iron ores. The slight difference in their iron ore values is due to differences in data collection methods, coverage, and objectives.

Four sources present statistics relating to the purchase and use of iron and steel scrap. The AISI annual statistical reports provide shipments of finished steel; imports; exports; blast furnace production (weekly); raw steel production (monthly); and scrap consumption (by grade and by furnace), stocks, production, shipments, and "scrap received," which are deliveries of both obsolete and promp scrap. The Bureau of Mines Minerals Yearbook (Vol. I) and Mineral Industry Surveys review iron and steel scrap prices for the iron and steel industry, but otherwise depend on AISI data. The section on iron and steel scrap presents data on supply, consumption, stocks, prices, and foreign trade that are based not only on AISI data, but also on monthly census surveys of steel-casting manufacturers and iron foundries. Various Bureau of Census industrial reports cover steel inventories, scrap consumption, foundry shipments, and foundry charge metallics. The Census of Manufactures is perhaps the most complete source of information.

The two basic sources -- AISI and the Bureau of the Census -- yield few contradictions in data on steel ingot producers. However, the data on steel casting and iron foundries are marred by underreporting ${ }^{20}$ and mixing of output between industries.

Finally, the trade associations connected with the industries regularly collect their own statistics. The most important are AISI, whose products roughly correspond to SIC 331 without the SIC 3313 electrometallurgical products, the Institute of Scrap Iron and Steel (ISIS), and the American Iron Ore Association (AIOA). 
Table 3.1 Current Periodicals on Iron and Steel

U.S. Government Publications

Nongovernment Sources

:

Bureau of Mines

Iron Ore

Iron \& Steel, reported monthly and annually in Mineral Industry Surveys

Iron \& Steel Scrap

Chapters in Mineral Commodity

Summaries

Minera1s Yearbook

Mineral Trade Notes (monthly)

Bureau of the Census

Annual Survey of Manufacturers, SIC 3312

Blast Furnaces and Steel Mills, various regular and spectal reports, 33121-11 to 33121-83 (includes coke ovens)

Annual Survey of Mineral Industries, SIC 1011

Iron Ores, various regular and special reports

Dept. of Energy, Energy Information Administration

Energy Data Reports

Coke and Coal Chemicals, annually (Bureau of Mines publication prior to 1975)

Energy Research Abstracts, Metals Industry entries
American Institute of Mining, Metallurgical, and Petroleum Engineers

Annual proceedings of the Iron and Steel Society's Ironmaking Division, Open Hearth and Basic Oxygen Steel Division, and Electric Furnace Division Mining Englneering

American Iron and Steel Institute, annual reports

American Iron Ore Association, annual reports

Other Publications

33 Metal Producing, annual (McGrawHi11)

American Metal Market

Engineering and Mining Journal

Iron Age

Iron and Steel Engineer

Iron and Steel International

Ironmaking and Steelmaking (quarterly)

Metal Bulletin (London)

Metal Statistics (Frankfurt)

Metals Week

Mining Congress Journal

Mining Magazine/Mining 'Journal

(London)

Steel Times

World Metal Statistics (World Bureau of Metal Statistics, London)

World Mining 


\subsection{TOTAL ENERGY AND MATERIALS FLOWS}

As Table 3.2 indicates, the iron and steel industry has accounted for around $4 \%$ of total domestic energy consumption for a considerable time. Table 3.3, which gives the percentage breakdown of this consumption, shows that coal accounts for about $65 \%$ of the total during 1972-1980.

Within the manufacturing sector (excluding refining), the iron and steel industry is second only to chemicals and allied products, regardless of whether feedstock energy use is counted or not. If the coal used to produce reductant coke is counted, then the industry consumed about $17 \%$ of the total feedstock and energy purchased by all industry in 1974. If only purchased energy is counted, the figure rises to $20 \%$.
Table 3.2 Total Energy Consumption in the United States and the Domestic Steel Industry

\begin{tabular}{llrr}
\hline & & \multicolumn{2}{c}{ Steel } \\
\cline { 3 - 4 } Year & $\begin{array}{c}\text { Total } \\
\left(10^{15} \text { Btu }\right)\end{array}$ & $\begin{array}{r}10^{15} \\
\text { Btu }\end{array}$ & $\begin{array}{r}\% \text { of } \\
\text { Total }\end{array}$ \\
\hline & & & \\
1972 & 71.63 & 3.13 & 4.4 \\
1973 & 74.61 & 3.45 & 4.6 \\
1974 & 72.76 & 3.42 & 4.7 \\
1975 & 70.71 & 2.94 & 4.2 \\
1976 & 74.51 & 3.05 & 4.1 \\
1977 & 76.54 & 2.91 & 3.8 \\
1978 & 78.15 & 2.98 & 3.8 \\
1979 & 78.97 & 2.84 & 3.6 \\
1980 & 76.2 & 2.27 & 2.9 \\
& & & \\
\hline
\end{tabular}

Source: Ref. 6 (p. 191) for 197278; Ref. 23 for $1979-80$.

Since the purpose of this

document is to describe the materials, direct and indirect energy flows, and flow interactions for the entire industry, with emphasis on which processes consume which materials, the approach of many other investigators will be followed, with the analysis carried backward to the mining or recovery of the primary raw materials. In the downstream direction, stopping at the raw steel stage allows this volume to mesh with an earlier Argonne National Laboratory (ANL) report, which covered the energy and materials flows in the steps following the production of raw steel through the final fabrication of semifinished products. 24

If the purpose were to obtain a complece pleture of the dlrect and indirect energy and materials flows for the industry, the only completely correct methodology to adopt would be an energy and materials $1 / 0$ analysis, 25 or a full process analysis, which counts not only the fuel and materials used, but also the fuel and materials used to produce the fuel and other inputs, the fuel and materials used to produce the inputs to the other inputs, etc. Two sources are avallable for this approach -- the Bureau of Economic Analysis I/O tables, and the work of Hannon and others at the University of Illinois. 25,26 For reasons mentioned previously, this present analysis is limited to:

- The direct energy and materials used in each of the processes in SIC 3312 blast furnaces and steel mills; 
Table 3.3 Steel Industry Energy Consumption by Source (\%)

\begin{tabular}{|c|c|c|c|c|c|c|c|c|c|}
\hline Source & 1972 & 1973 & 1974 & 1975 & 1976 & 1977 & 1978 & 1979 & 1980 \\
\hline $\begin{array}{l}\text { Coking coal } \\
\text { Steaming coal } \\
\text { Coal purchased as coke } \\
\text { Subtotal }\end{array}$ & $\begin{array}{r}64 \\
3.5 \\
1.3 \\
68.8\end{array}$ & $\begin{array}{r}64.5 \\
3.4 \\
1.7 \\
69.6\end{array}$ & $\begin{array}{r}62.1 \\
2.9 \\
2.8 \\
67.8\end{array}$ & $\begin{array}{l}66.8 \\
2.6 \\
(1.5) \\
67.9\end{array}$ & $\begin{array}{l}65.7 \\
2.4 \\
(0.9) \\
67.2\end{array}$ & $\begin{array}{r}62.4 \\
2.9 \\
0.9 \\
66.2\end{array}$ & $\begin{array}{r}56.3 \\
2.4 \\
5.8 \\
64.5\end{array}$ & $\begin{array}{r}54.8 \\
2.7 \\
6.2 \\
63.7\end{array}$ & $\begin{array}{r}57 \\
0.6 \\
6.4 \\
64\end{array}$ \\
\hline $\begin{array}{l}\text { Natural gas } \\
\text { Petroleum } \\
\text { Liquid petroleum gas } \\
\text { Purchased electricity }\end{array}$ & $\begin{array}{c}20.7 \\
6.2 \\
- \\
4.3\end{array}$ & $\begin{array}{c}19 \\
6.9 \\
- \\
4.5\end{array}$ & $\begin{array}{l}20 \\
7.6 \\
- \\
4.6\end{array}$ & $\begin{array}{l}20 \\
7.3 \\
0.1 \\
4.7\end{array}$ & $\begin{array}{l}19.9 \\
7.8 \\
0.1 \\
5\end{array}$ & $\begin{array}{r}19.9 \\
8.6 \\
0.1 \\
5.2\end{array}$ & $\begin{array}{r}20.5 \\
9.4 \\
0.1 \\
5.5\end{array}$ & $\begin{array}{r}22.6 \\
7.9 \\
0.1 \\
5.7\end{array}$ & $\begin{array}{l}24 \\
5 \\
0.1 \\
6\end{array}$ \\
\hline Tota 1. & 100 & 100 & 100 & 100 & 100 & 100 & 100 & 100 & 100 \\
\hline
\end{tabular}

Source: Ref.6 (p. 191) for 1972-78; Ref. 23 for 1979-80.

- The feedstock (reductant) energy used -- e.g., coal and coke -- by SIC 3312 facilities;

- The direct energy and materials used in iron ore mining (SIC 1110);

- The direct energy used in scrap collection;

- The direct energy used to produce a few select energyintensive inputs to these industries, e.g., explosives, limestone, fluorspar, electricity, and oxygen. (Oxygen's contribution to indirect energy use in steelmaking is described in another ANL report. ${ }^{27}$ )

While this approach is neither purely direct nor indirect, it strikes a balance, retaining the simplicity of the direct approach without ignoring the major sources of indirect energy use in the industry.

There are several ways to present the energy and materials flow data so collected -- by ellergy and materlal type, or by the process which consumes or produces these flows. Within each, total energy and materials or energy and materials intensities (e.g., tons/ton, Btu/ton, gal/ton) can be calculated. ,

The simplest method is shown in Table 3.4. This table presents, for 1980, the direct and indirect, and direct-only, energy consumption by type for SIC 331 less 3313 facilities (1.e., the AISI Industry classification), based on data in the AISI annual reports and other sources cited. 
Table 3.4 1980 Domestic Energy and Materials Use by Energy and Materials Type

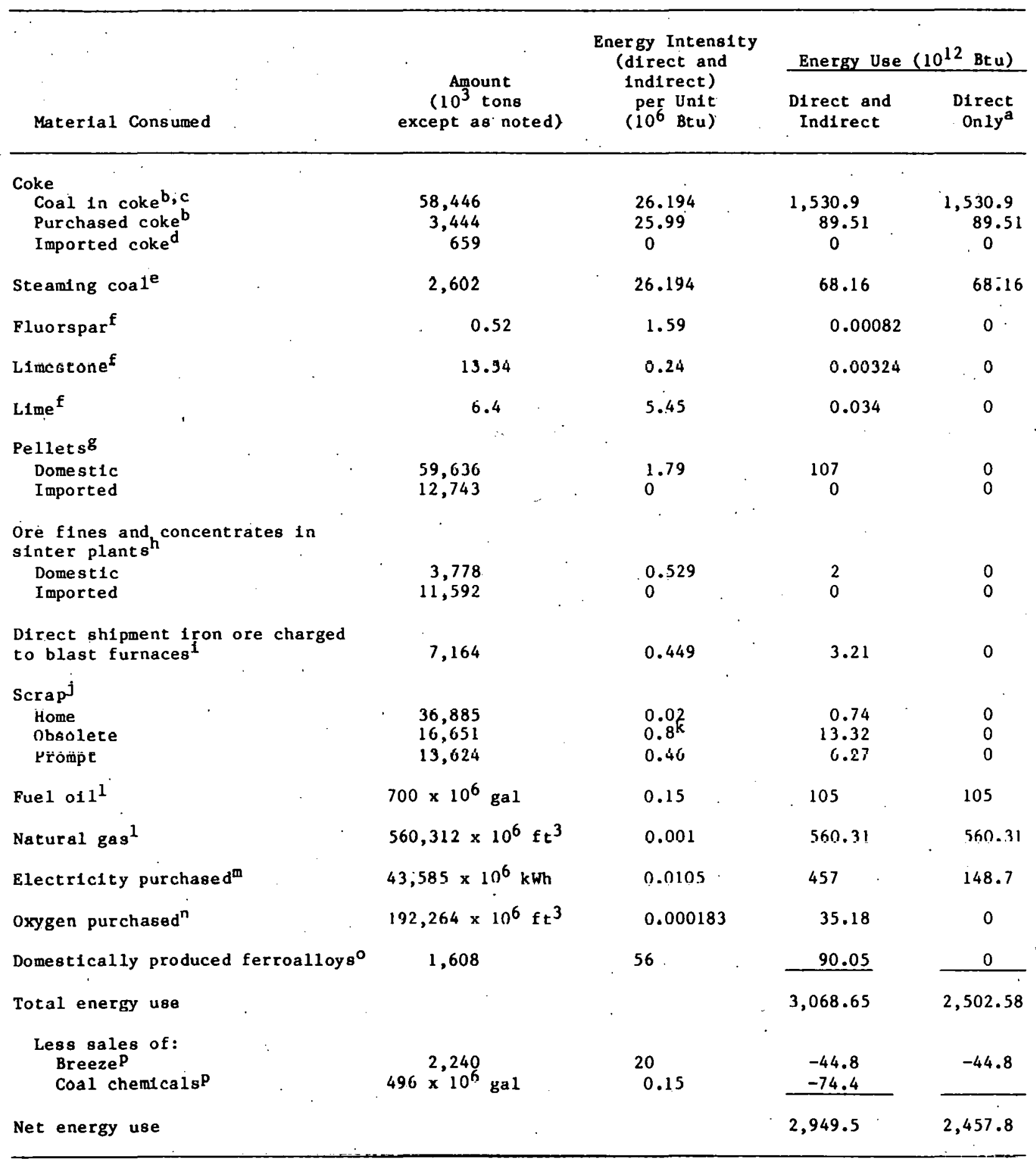




\section{Table 3.4 (Cont'd)}

ancludes feedstock.

${ }^{b}$ Amount from Ref. 1 (Table 39); coking coal conversion ratio from Ref. 22 (p. 6).

${ }^{c}$ Coke produced is $39,276 \times 10^{3}$ tons.

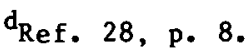

eAmount from Ref. 1 (Table 37); coking coal conversion ratio from Ref. 22 (p. 6).

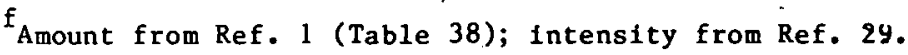

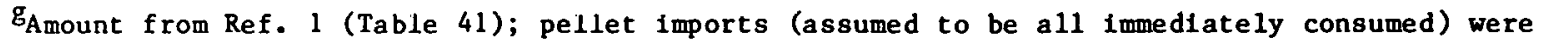
subtracted from total material consumed to yield domestic pellet amount. Intensity from Ref. 30 (includes $0.309 \times 10^{6}$ Btu for transport).

hAmount from Ref. 16; intensity from Ref. 30 (1ncludes $0.309 \times 10^{6}$ Btu for transport).

${ }^{i_{A m o u n t}}$ from Ref. 1 (Table 40), reflecting tgtal blast furnace consumption less agglomerates; intensity from Ref. 30 (includes $0.309 \times 10^{6}$ Btu for transport).

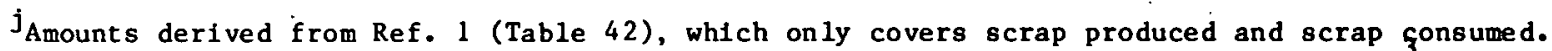
The difference between them is the total for prompt and obsolete scrap, $30,275 \times 10^{3}$ tons, of which prompt scrap accounts for 55\%. Intensities from Ref. 31 (pp. 63-64, 66).

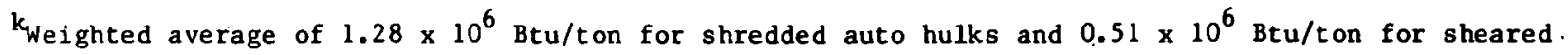
scrap.

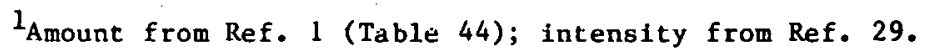

mAmount from Ref. 1 (Table 45); intensity from Ref. 29.

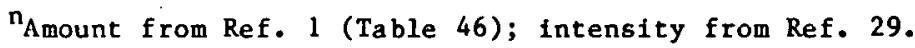

${ }^{\circ}$ Amount from Ref. 1 (Table 34); intensity given is weighted average of ferroalloy Intensities in Ref. 29.

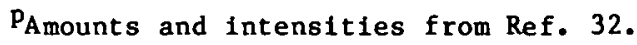

The table is designed to allow the analyst to modify the total to sult different purposes. For exámple,

- Direct energy and feedstock use in SIC 331 less 3313 (the AISI energy consumption figures) can be obtalned by summing coal and coke, fuel oil, natural gas, and electricity purchased, the latter valued at $3412 \mathrm{Btu} / \mathrm{kWh}$. This is the energy and feedstock use figure reported by AISI to DOE's voluntary energy efficiency improvement program. .

- Direct energy use can be obtained by subtracting the Btu values corresponding to total domestic coke consumed, and by valuing electricity at $3412 \mathrm{Btu} / \mathrm{kWh}$. This direct energy use figure is the one usually reported by the Census of Manufactures. 
- Energy use inputs to the iron and steel industry from SIC 1011 (iron mining) can be obtained by summing the Btu values for domestic pellets, fines, and direct-shipped ore.

- Energy use in scrap can be obtained by summing the Btu values for prompt, home, and obsolete scrap.

- Domestic energy saved through imports by the iron and steel industry can be approximated by substituting the domestic energy intensities for the zero values given imports, and summing.

\subsection{FLOW3 DY MAJOR FROCESS}

The same data can be used to present 1980 usage by each major process in the industry by a judicious use of the totals, plus additional process energy intensity data presented later in this report. Table 3.5 shows the data arrayed in that fashion. (Since the data in Tables 3.4 and 3.5 were derived using slightly different assumptions, the final totals do not match, but vary by less than $1 \%$ As Table 3.5 indicates, the blast furnace, consuming almost $1,100 \times 10^{12}$ Btu of coke, or $37 \%$ of total direct and indirect consumption, is the largest single consumer of energy. Heating/annealing furnaces follow with $15 \%$, while coke ovens consume $7 \%$ of the energy. The rest of the process uses less. The heating value of the coke is a matter of some dispute; Battelle assesses it at $31.5 \times 10^{6} \mathrm{Btu} / \mathrm{ton} .33$ In the table, $26 \times 10^{6}$ $B t u / t o n$ was used. If the Battelle value had been used, the allocation of energy use between coke and Iron production would have changed. Coke production would have dropped to $4 \%$, while blast furnace use would have risen to $44 \%$.

The data can also be presented in terms of process energy intensity per ton of output for each process, which is perhaps the most illuminating way when considering variations among years and between established and emerging technologies. These calculations require a common denominator: metal flow is the obvious choice. Frequently, mining intensities are presented using tons of iron content as the denominator. In Table 3.6, this is not done; gross tons are used instead ( $t$ ons of ore mined, tons of concentrates, etc.). The only convention is that all intensities are normalized on the basis of tons of usable output, e.g., energy intensity in the concentration of ores is based on energy use per ton of concentrates, blast furnace intensity is based on energy use per ton of hot metal, etc.

Finally, the time pattern of total energy intensity in steelmaking has been calculated by AISI as part of the government's voluntary energy conservation program. 23 The trend in energy use per ton of finished steel shipped is plotted in Fig. 3.1 , as well as total energy use. The figure shows almost a $10 \%$ reduction in energy use per ton since 1972 , an accomplishment not 
even equaled by the Japanese steel Industry during the same period. If steel production were also plotted, the well-documented inverse relation between steel volume and energy consumption per ton would be apparent. This relation is caused 'by many factors: fixed "housekeeping" energy expenditures; nonproductive energy use, such as banking and firing of furnaces; heat-up fuel for mills; mismatched capacity utilization at lower throughput rates; etc. 35 
Table 3.51980 Domestic Energy and Materials Use by Major Process

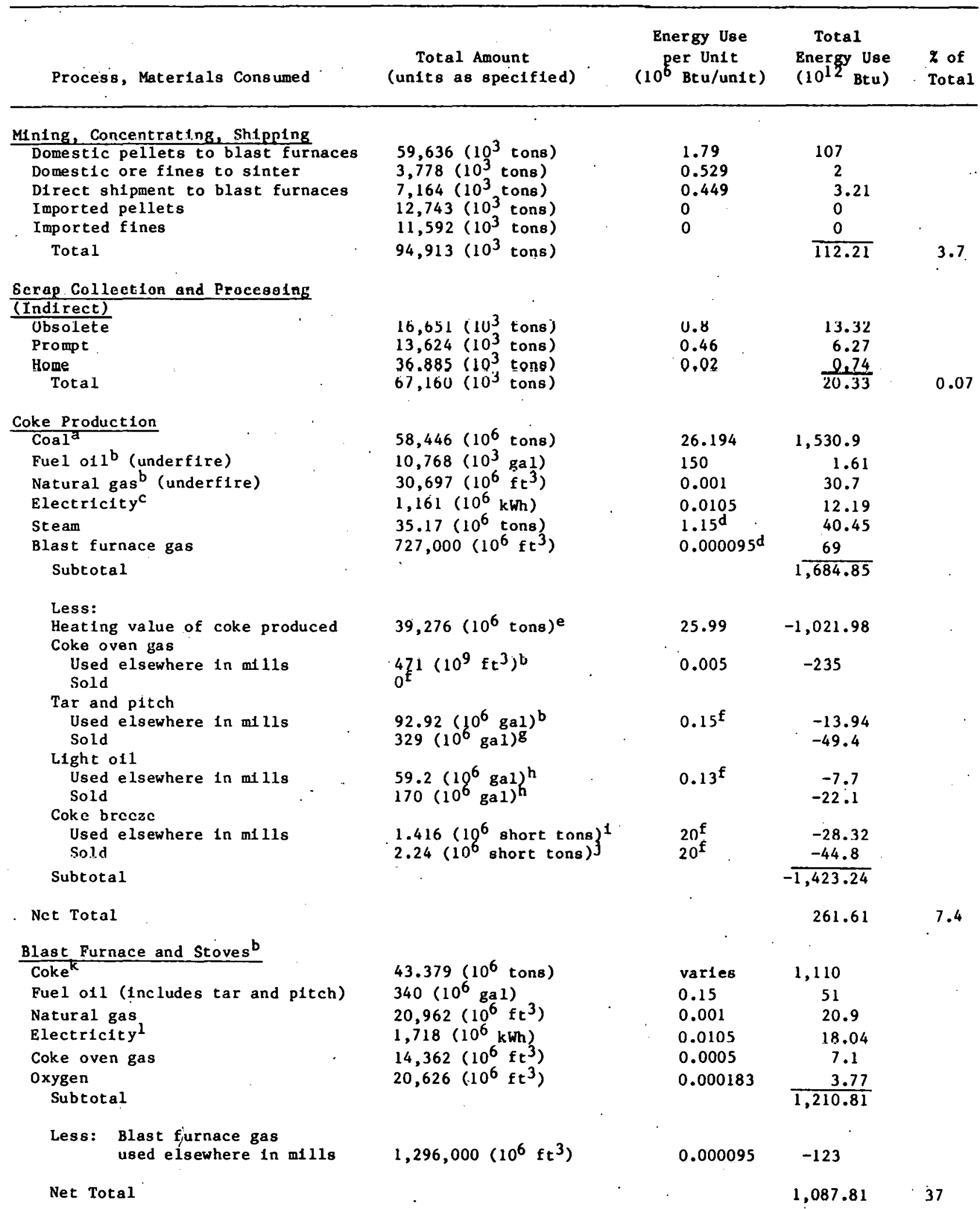


Table 3.5. (Cont'd)

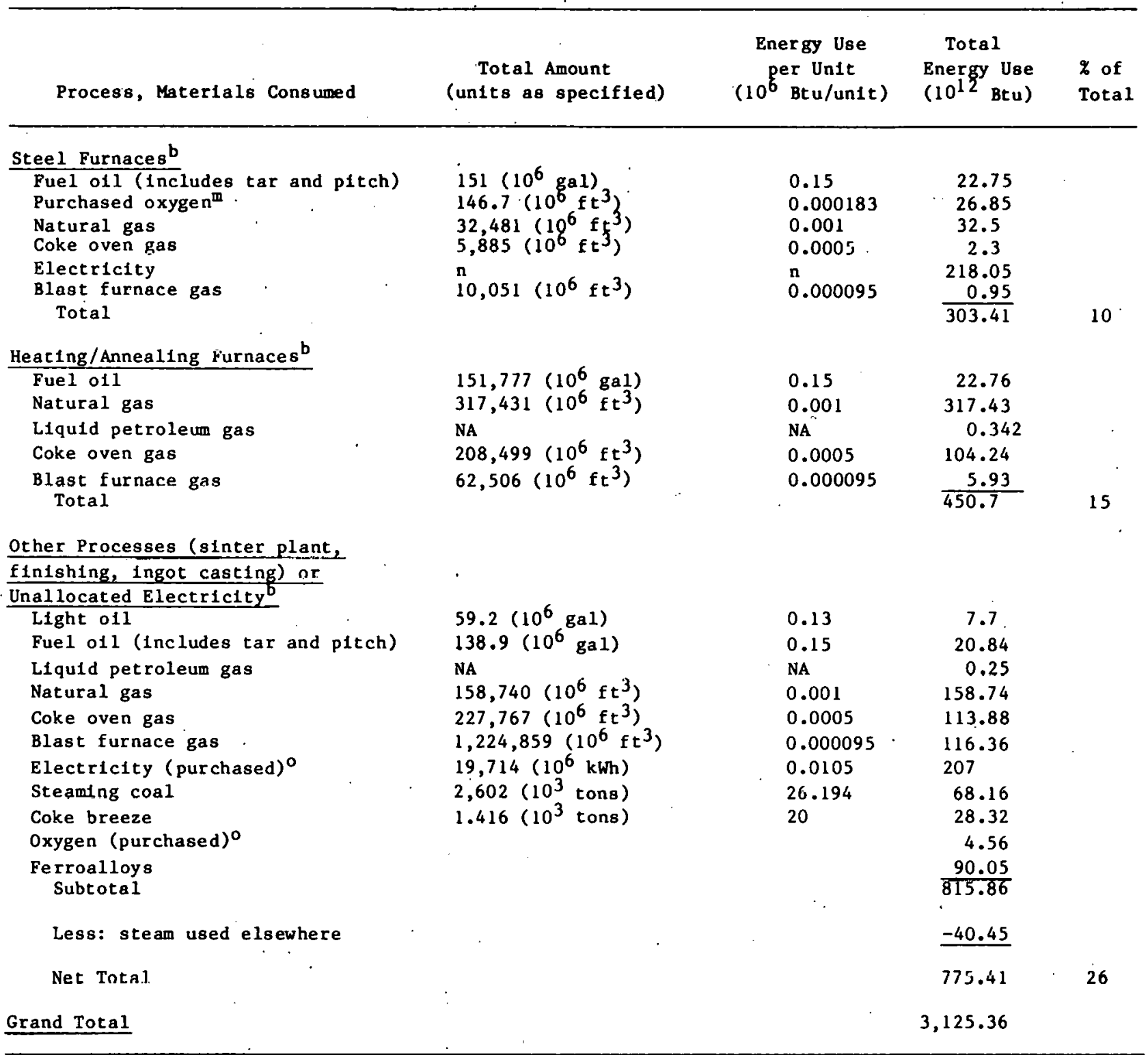

${ }^{a}$ Ref. 1 (Table 37).

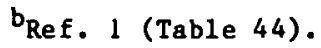

cralculated by multiplying clcctrielty intensities in Table 6.6 by total 1980 tonnage for each product.

$\mathrm{d}_{\text {Ref . } 29 .}$

e Ref. 1 (Table 39).

$f_{\text {Ref. }} 33$ (conversion chart).

gef. 34 (Table 25).

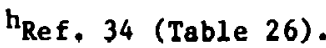

$1_{\text {Ref. } 1 \text { (Table 41). }}$

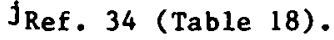

kata from various sources.

${ }^{1}$ Calculaced by üultiplying electrictty Intensities in Table 7.1 by total 1980 tonnage for each product.

$\mathrm{m}_{90 \%}$ is purchased.

$\mathrm{n}_{\text {Calculated by multiplying electrictty }}$ intensities in Tables $10.2,10.3$, and 10.4 by total 1980 tonnage for each product.

OUnallocated remalning.

NA = not avallable.

Source: Table 3.4 , except as noted. 
Table 3.6 Direct Energy Intensity per Ton of Product

$\left(10^{6} \mathrm{Btu} /\right.$ ton $)$

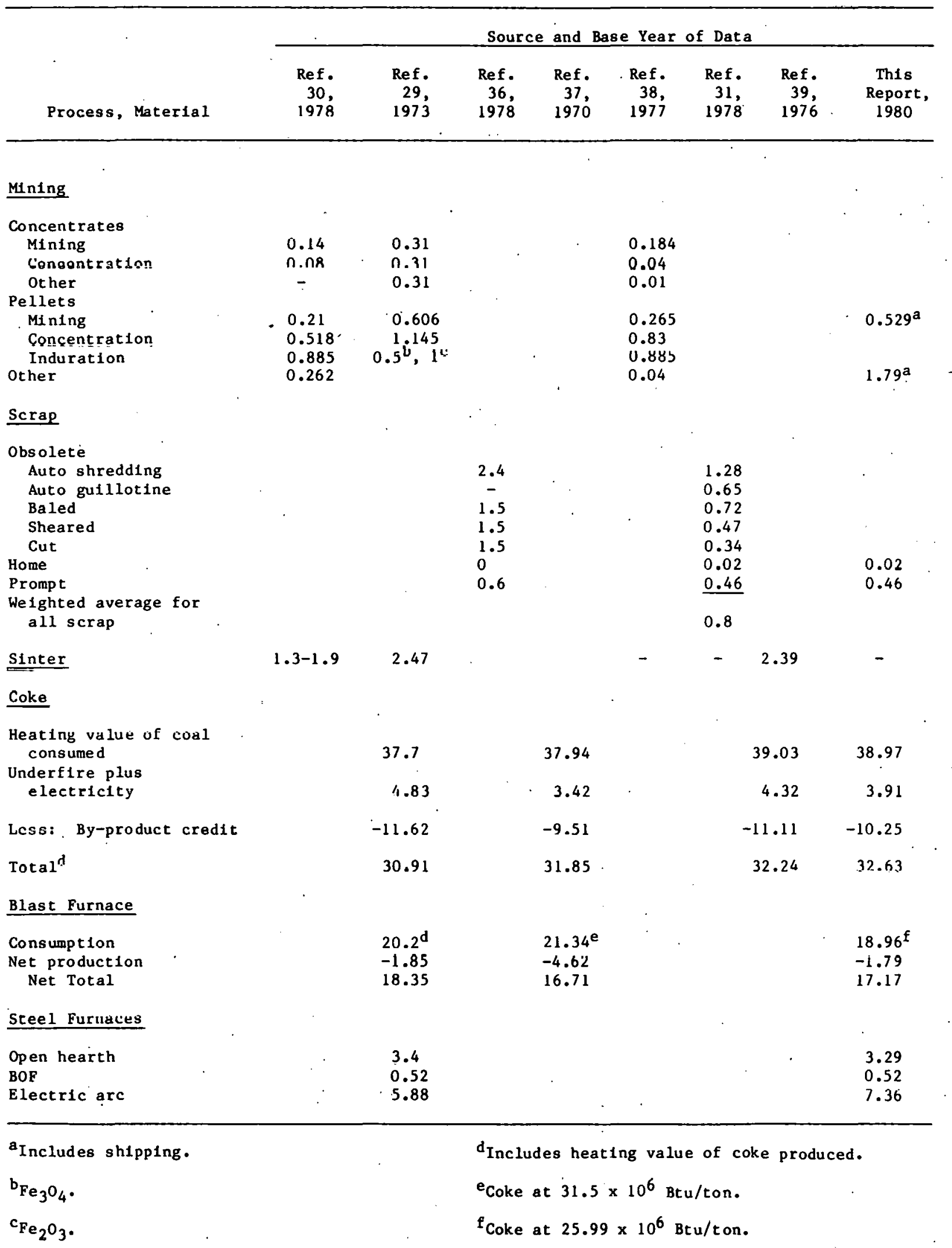



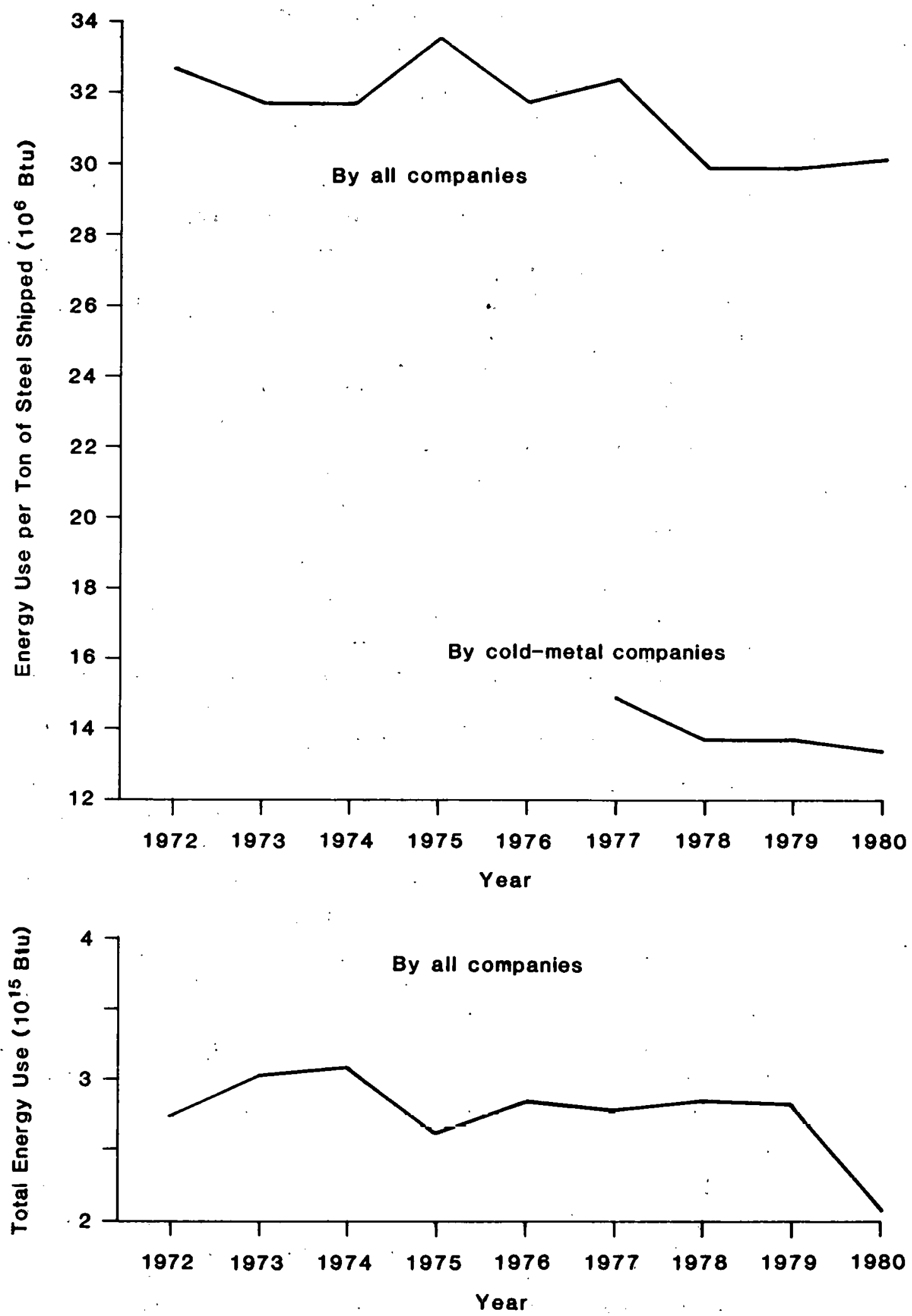

Fig. 3.1 Energy Use in the Steelmaking Industry, 1.972-1980

(Source: Based on Ref. 23 data) 
4 OPERATIONS NEAR THE MINE

\subsection{RESERVES}

Table 4.1 describes the major types of deposits that contain sources of iron, their present importance, and their resource potential both in the United States and abroad. There are five principal iron ores: hematite $\left(\mathrm{Fe}_{2} \mathrm{O}_{3}\right)$, magnetic taconite, nonmagnetic taconite, specular hematite, and iron laterites. 40 High-grade $(60 \% \mathrm{Fe})$ hematite ores require no beneficiation, and are directly shipped to blast furnaces or sinter plants. The Great Lakes deposits are nearly exhausted.

Magnetic taconites are presently the primary ores of the industry. In the form of magnetite $\left(\mathrm{Fe}_{3} \mathrm{O}_{4}\right)$, they average $22-35 \% \mathrm{Fe}$ and $40-50 \% \mathrm{SiO}_{2}$; hence, they are fine-grained, dense, and hard. Figure 4.1 shows a typical pellet beneficiation plant for such taconites. Ninety-five percent of the magnetite is recovered, and it takes 3.2 tons of ore to produce one ton of pellets containing $63 \%$ magnetite and $8 \% \mathrm{SiO}_{2}$.

The nonmagnetic taconites can be richer than the magnetic taconites, containing $28-40 \%$ iron in the form of hematite and limonite $\left(\mathrm{Fe}_{2} \mathrm{O}_{3} \mathrm{H}_{2} \mathrm{O}\right)$, but they are more expenstve to concentrate due to the absence of magnetic ores. Magnetic separation can occur either by using very high intensity (approximately 20,000 gauss field strength) separation of the hematite, or by converting the hematite to magnetite by roasting.

Specular hematite is about $50 \%$ crystalline hematite and $50 \%$ granular quartz, which can be separated after crushing by flotation, then pelletized. It is of some importance, since there are deposits being mined in Michigan and reserve deposits in Quebec. (U.S. Steel's "QCM" concentrate is specular hematite.)

The iron laterites -- geothite and limonite, in particular -- are decomposition products of the primary iron minerals, and account for major amounts of southern production. ${ }^{41}$ They usually contain valuable by-products such as nickel, chromium, and alumina, which can be recovered during concentration. The ore is usually crushed, roasted, screened to permit magnetic separation of the magnetite produced by the roasting process, and finally pelletized.

Further details on reserves are given in Table 4.2. This table combines high- and low-grade ores; therefore, reglonal tonnages are not directly comparable. Even if the conservative assumption is made that al1 reserves are low-grade, there is still. enough world supply to last 100 years at current production rates. The U.S. and Canadian reserves of 45 billion tons are sufficent alone to sustain North American steel production for 125 years at 1980 crude ore production rates. Nonetheless, U.S. high-grade ores are almost 
Table 4.1 Categories of Iron Ore

\begin{tabular}{|c|c|c|c|c|c|c|c|}
\hline \multirow{2}{*}{ Category } & \multirow{2}{*}{$\begin{array}{l}\text { Lecation } \\
\text { of Typical } \\
\text { Example }\end{array}$} & \multirow[b]{2}{*}{$\begin{array}{c}\text { P-:-1ncipal } \\
\text { Iros Minerals }\end{array}$} & \multirow{2}{*}{$\begin{array}{l}\text { Average } \\
\text { Iron } \\
\text { Content } \\
(\boldsymbol{X})\end{array}$} & \multirow[b]{2}{*}{$\begin{array}{c}\text { Form of } \\
\text { Explo1ted Deposits }\end{array}$} & \multirow[b]{2}{*}{$\begin{array}{c}\text { Present } \\
\text { Importance }\end{array}$} & \multicolumn{2}{|c|}{ S1ze of Reserves } \\
\hline & & & & & & $\begin{array}{l}\text { United } \\
\text { States }\end{array}$ & Wor1d \\
\hline Sedimentary deposits & & & & & & & \\
\hline Banded Iron formation & Labrador & $\begin{array}{l}\text { Magnetite, hematite, } \\
\text { siderite, Iron silicate }\end{array}$ & 33 & $\begin{array}{l}\text { Beds hundred's of feet thick, } \\
\text { strikes tens of miles long. }\end{array}$ & Major & Enormous & Enormous \\
\hline Ironstone & $\begin{array}{l}\text { B1 rmi ngham, } \\
\text { Ala. }\end{array}$ & $\begin{array}{l}\text { Limonite, hematite, } \\
\text { siderite, chamosite }\end{array}$ & 30 & $\begin{array}{l}\text { Beds tens of feet thick, strikes } \\
0-10 \text { miles long. }\end{array}$ & Minor & Medium & Large \\
\hline $\begin{array}{l}\text { M1scellaneous (bog } \\
\text { lron, black band sid- } \\
\text { erite, Jlack sands) }\end{array}$ & & $\begin{array}{l}\text { Limonite, siderite, } \\
\text { magnet1te, 11mente }\end{array}$ & - & Various forms & Negligibie & Sma11 & Simall \\
\hline $\begin{array}{l}\text { Deposits related direct 1y } \\
\text { to 1gneous activity }\end{array}$ & & . & & $\cdot$ & & . & \\
\hline Magmat1c segregations & $\begin{array}{l}\text { XI runa, } \\
\text { Sweden }\end{array}$ & Magnetite & .65 & $\begin{array}{l}\text { Tabular, hundreds of feet thick, } \\
\text { many thousands of feet long. }\end{array}$ & Modest & Medium & Medium \\
\hline $\begin{array}{l}\text { Pyrometasomatic } \\
\text { deposit: }\end{array}$ & $\begin{array}{l}\text { Cornvall, } \\
\text { Penn. }\end{array}$ & Magnetite, hematite & 45 & $\begin{array}{l}\text { Tabular to podlike, a few hundred } \\
\text { feet thick, a few thousand feet long. }\end{array}$ & Modest & Large. & Medium \\
\hline $\begin{array}{l}\text { Depos 1t s formed by } \\
\text { hydrotherma1 solutions }\end{array}$ & $\therefore \quad$. & : & & & . & & \\
\hline $\begin{array}{l}\text { Replacement deposits } \\
\text { In nonferruginous rocks }\end{array}$ & $\begin{array}{l}\text { Buena V1sta, } \\
\text { Nev. }\end{array}$ & $\begin{array}{l}\text { Magnetite, hematlte, } \\
\text { siderite }\end{array}$ & 30 & $\begin{array}{l}\text { Irregular pods, lenses, stockworks, } \\
\text { velns }\end{array}$ & Minor & Sma 11 & Small \\
\hline $\begin{array}{l}\text { Enrichments of preexist- } \\
\text { Ing ferruginous rocks }\end{array}$ & $\begin{array}{l}\text { Mings Gerals, } \\
\text { Braz11 }\end{array}$ & Specular hematite & 68 & $\begin{array}{l}\text { Tatular, parallel or subparallel } \\
\text { to bedding of enclosing } 1 \text { ron } \\
\text { formation. Up to several hundred } \\
\text { feet thick. }\end{array}$ & Modest & Negligible & Medium \\
\hline $\begin{array}{l}\frac{\text { Laterite deposits }}{\text { produced by surface or }} \\
\text { near-8urface enrlchment }\end{array}$ & Cuba & Limonite, hematite & 45 & $\begin{array}{l}\text { Blankets, tens of feet thick, tens } \\
\text { or hundreds of square miles in } \\
\text { area. }\end{array}$ & Minor & Sma11 & Larige \\
\hline $\begin{array}{l}\text { Secondary enriclonents } \\
\text { of low-grade 1ron } \\
\text { deposite }\end{array}$ & $\begin{array}{l}\text { Lake Supertor } \\
\text { reglon (for } \\
\text { d1rect- } \\
\text { sh1pping and } \\
\text { wash ores) }\end{array}$ & Limonite, hematite & 55 & $\begin{array}{l}\text { Blankets to sacklike bodies, } \\
\text { dimensions in hundreds to } \\
\text { thousands of feet. Most are a } \\
\text { few hundred feet below surface, } \\
\text { but Lake Superior deposits } \\
\text { extend to several thousand feet. }\end{array}$ & Major & Large & Large \\
\hline
\end{tabular}

Source: Adapted from Ref. 42. 


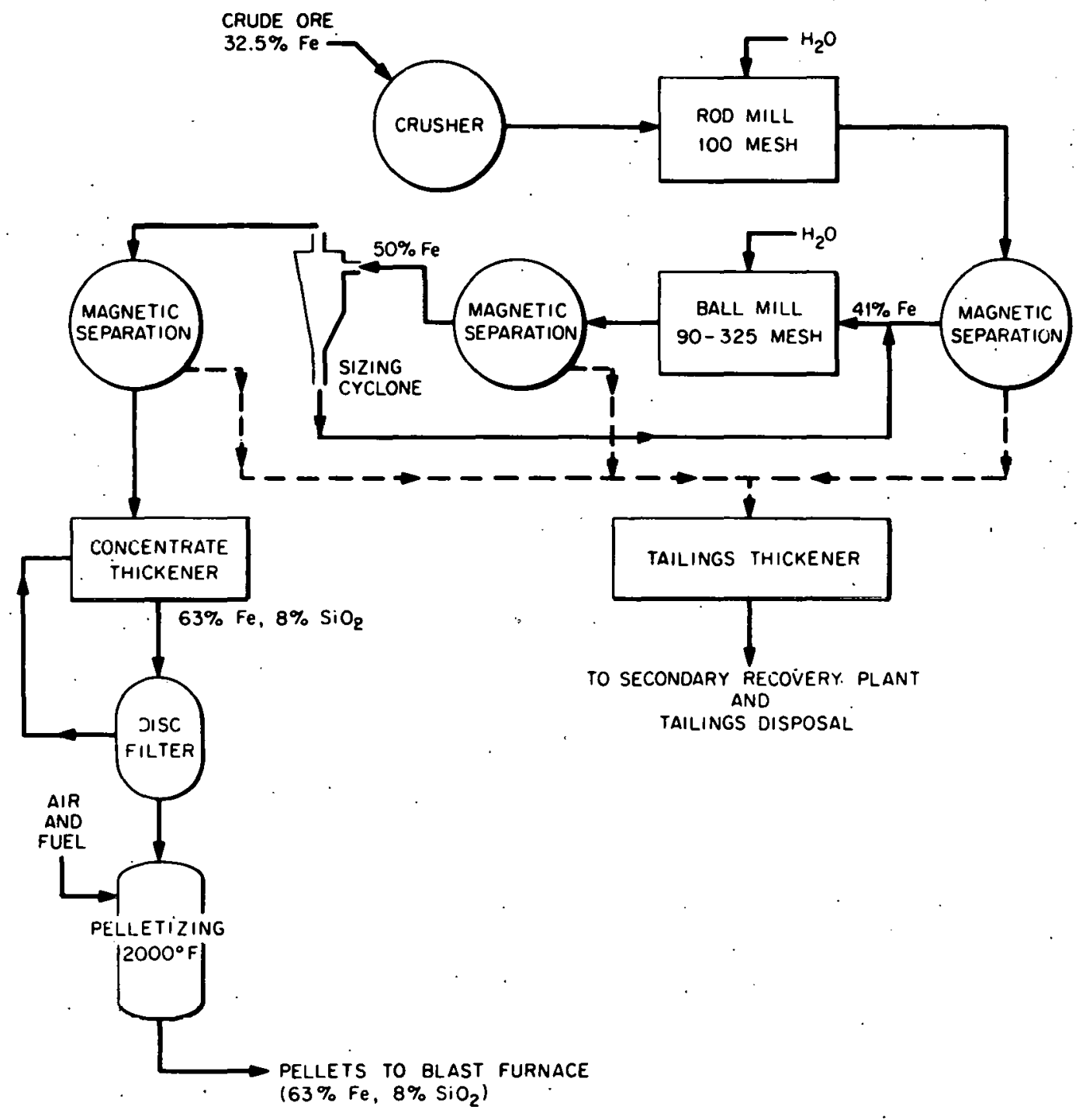

Fig. 4.1 Beneficiation of Magnetic Taconites

(Source: Ref. 40)

exhausted; it was' estimated that, in 1968, only one-fourth of the Lake Superior high-grade $(51 \% \mathrm{Fe})$ ore remained after a century of exploitation. 37

\subsection{MINING}

Figure 4.2 shows the materials flows for mining, agglomeration, imports, and exports of iron ore and ore agglomerates for 1980. Data are from the 1980 AISI and AIOA annual reports and Table 4.3. The data differ slightly from those reported in other sources, but not enough for concern. 
Table 4.2 World Iron Ore Resources $\left(10^{6}\right.$ metric tons)

\begin{tabular}{lcr}
\hline & Identified Resources \\
\cline { 2 - 3 } & & $\begin{array}{r}\text { Reserves } \\
\text { Geographic Area } \\
\text { Only }\end{array}$ \\
& Total & \\
North America & & 9,000 \\
United States & 101,000 & 36,000 \\
Other (most ly Canada) & 126,000 & 34,000 \\
South America & 94,000 & 21,000 \\
Europe & 34,000 & 7,000 \\
Africa & 31,000 & 17,000 \\
Australia and New Zealand & $17,000^{c}$ & 17,000 \\
Asia & 72,000 & 111,000 \\
Soviet Union & 304,000 & 252,000 \\
$\quad$ Total & 779,000 & \\
& &
\end{tabular}

adentified deposits whose extent and grade may or may not be evaluated, and whose contained minerals may or may not be profitably recovered with existing technology and under present economic conditions.

${ }^{b}$ Identified deposits from which minerals can be extracted profitably with existing technology and under present economic conditions.

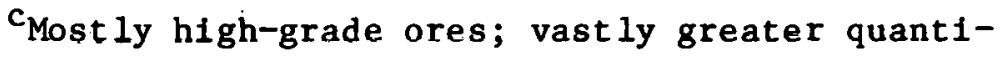
ties of lower-grade iron formations are known but have not been assessed.

Source: Adapted from Ref. 42 .

To see the trend over time of the flows, Table 4.3 gives U.S. Iron ore mining and shipping data. The data reveal the impact of fluctuating U.S. iron and steel production on crude ore production and shipments of the various concentrates, as well as the continuing substitution of taconte pellets for direct shlpping ores (11monite, hematite) as the latter ores become scarce. Figure 4.3 shows this substitution even more clearly; since 1967, the pellet percentage has grown from $30 \%$ to nearly $70 \%$, while directly shipped ores have decreased from $30 \%$ to less than $10 \%$. Table 4.4 shows U.S. consumption of iron 


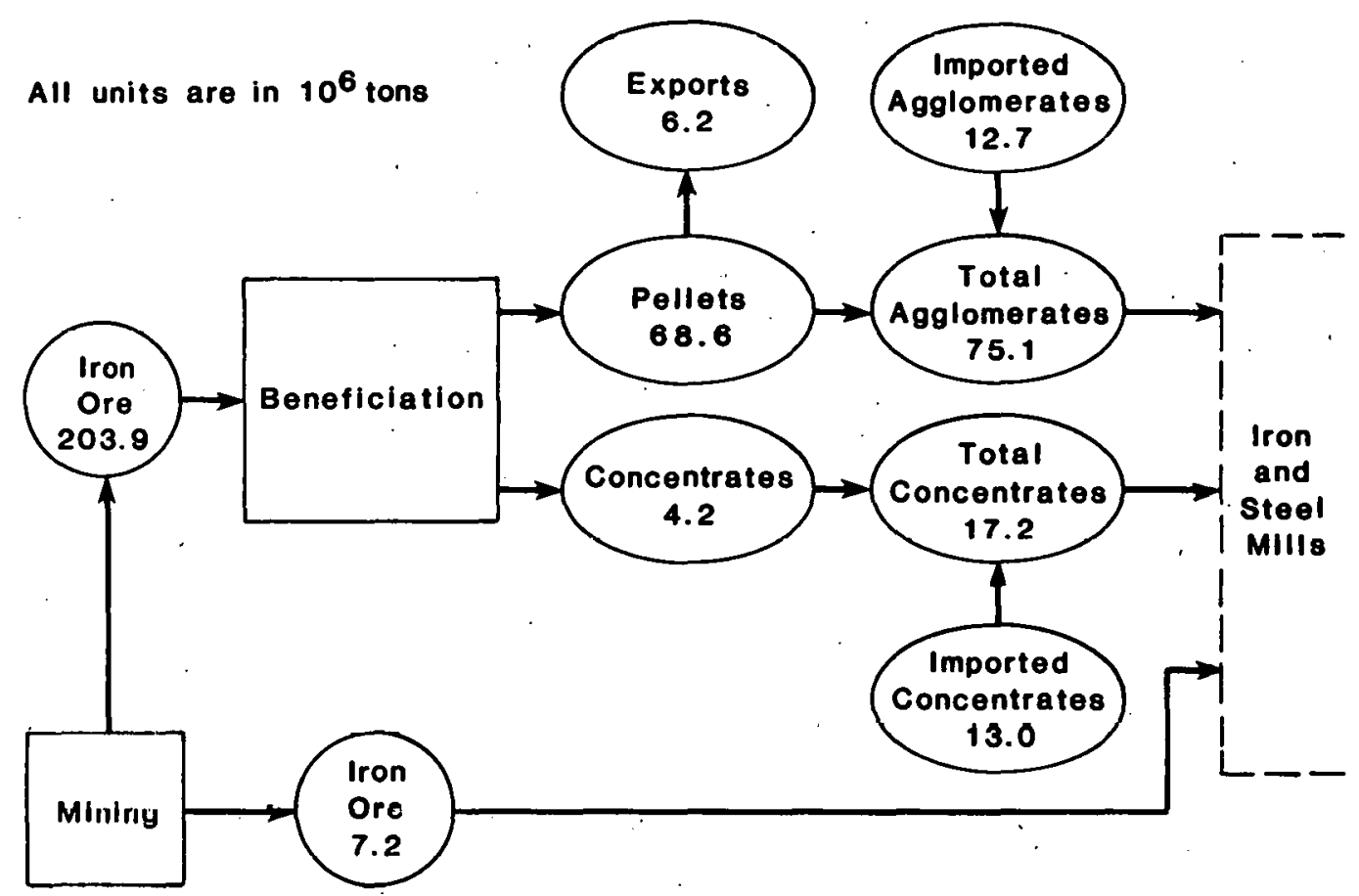

Fig. 4.2 Materials F1ows in Mining and Beneficiation, 1980 (Source: Refs. 1 and 16, and Table 4.3).

ore from all sources. Non-Canadian ore imports as a percentage of total receipts show a ratchet-like decline during the 1970s, with Canadian ores taking up the slack. Table 4.5 ind lcates that the mining of iron ore is not particularly energy-intensive; open-pit operations tend to be less energyintensive than underground mining. ${ }^{3}$ Taconite's mining intensity is higher than that of natural ores due to its greater toughness; taconite requires almost five times the explosive energy to mine.

There appear to be few opportunities to radically reduce energy consumption in iron ore mining, although the trend towards larger loading and hauling equipment will marginally reduce consumption. 30 Increasing iron ore imports is clearly an energy conservation strategy; importing $25 \%$ of domestic requirements, as at present, saves about $0.5 \times 10^{6}$ Btu per ton of $r$ aw steel produced. The possibility of importing ore rather than oil and lessening dependence on OPEC nations is attractive, although it tends to concentrate the burden of ofl independence on the domestic iron ore industry. If all ore had been imported in 1978, an additional $130 \times 10^{12}$ Btu could have been saved. Assuming that a barrel of imported oil contains $5.8 \times 10^{6} \mathrm{Btu}$, this would have reduced ofl imports by $22.4 \times 10^{6}$ barrels, roughly $2 \%$ of 1978 imports from OPEC nations. 
Table 4.3 U.S. Iron Ore Production and Shipments, 1973-1980a (gross tons)

\begin{tabular}{|c|c|c|c|c|c|c|}
\hline Material & Year & Great Lakes & Northeastern & Southern & Western & Total \\
\hline $\begin{array}{l}\text { Crude ore } \\
\text { mined : }\end{array}$ & $\begin{array}{l}1973 \\
1974 \\
1975 \\
1976 \\
1977 \\
1978 \\
1979 \\
1980\end{array}$ & $\begin{array}{l}183,680,322 \\
183,599,928 \\
185,169,748 \\
194,626,881 \\
130,220,726 \\
214,784,593 \\
234,984,926 \\
194,810,818\end{array}$ & $\begin{array}{r}6,806,120 \\
6,365,115 \\
5,150,420 \\
5,506,730 \\
3,659,230 \\
379,447 \\
858,507 \\
666,776\end{array}$ & $\begin{array}{l}8,492,991 \\
7,029,961 \\
7,249,961 \\
7,638,560 \\
7,033,315 \\
4,195,756 \\
4,936,868 \\
3,916,632\end{array}$ & $\begin{array}{l}17,795,432 \\
17,182,571 \\
15,049,673 \\
15,036,322 \\
15,558,733 \\
15,418,226 \\
14,928,414 \\
11,712,579\end{array}$ & $\begin{array}{l}216,774,865 \\
214,177,572 \\
212,619,802 \\
222,808,493 \\
156,472,004 \\
234,778,022 \\
255,708,715 \\
211,106,805\end{array}$ \\
\hline \multicolumn{7}{|l|}{ Production } \\
\hline Run of Mine & $\begin{array}{l}1973 \\
1974\end{array}$ & $\begin{array}{l}227,176 \\
200,476\end{array}$ & $\begin{array}{l}-- \\
--\end{array}$ & $\begin{array}{r}337,418 \\
\cdot 133,930\end{array}$ & $\begin{array}{l}1,540,734 \\
1,444,288\end{array}$ & $\begin{array}{l}2,205,328 \\
1,778,685\end{array}$ \\
\hline & $\begin{array}{l}1975 \\
1976 \\
1977 \\
1978 \\
1979 \\
1980\end{array}$ & $\begin{array}{c}111,225 \\
82,518 \\
61,767 \\
b \\
b \\
b\end{array}$ & $\begin{array}{l}-- \\
-- \\
b \\
-- \\
-- \\
--\end{array}$ & $\begin{array}{c}112,602 \\
91,246 \\
\text { b } \\
\text { b } \\
\text { b } \\
\text { b }\end{array}$ & $\begin{array}{l}1,088,091 \\
1,012,354 \\
1,457,735 \\
1,622,724 \\
1,218,777 \\
1,003,857\end{array}$ & $\begin{array}{l}1,311,918 \\
1,186,118 \\
1,545,502 \\
1,697,884 \\
1,327,300 \\
1,071,340\end{array}$ \\
\hline Coarse & $\begin{array}{l}1973 \\
1974 \\
1975 \\
1976 \\
1977 \\
1978 \\
1979 \\
1980\end{array}$ & $\begin{array}{c}9,708,421 \\
9,126,313 \\
4,825,518 \\
3,975,308 \\
2,557,808 \\
2,881,957 \\
\text { b } \\
\text { b }\end{array}$ & $\begin{array}{l}b \\
b \\
b \\
b \\
b \\
b \\
b \\
b\end{array}$ & $\begin{array}{l}\text { b } \\
\text { b } \\
b \\
\text { b } \\
\text { b } \\
\text { b } \\
\text { b } \\
\text { b }\end{array}$ & $\begin{array}{r}1,620,888 \\
1,310,587 \\
1,014,451 \\
1,173,020 \\
927,385 \\
647,310 \\
680,744 \\
638,362\end{array}$ & $\begin{array}{r}11,745,509 \\
10,915,482 \\
6,254,530 \\
5,521,092 \\
3,948,255 \\
3,690,117 \\
2,400,673 \\
1,243,538\end{array}$ \\
\hline Pines & $\begin{array}{l}1973 \\
1974 \\
1975 \\
1976 \\
1977 \\
1978 \\
1979 \\
1980\end{array}$ & $\begin{array}{r}10,213,751 \\
9,922,906 \\
6,148,216 \\
5,529,862 \\
3,141,561 \\
\text { b } \\
2,399,359 \\
2,107,336\end{array}$ & $\begin{array}{c}101,478 \\
132,548 \\
575,816 \\
1,120,018 \\
971,061 \\
b \\
b \\
--\end{array}$ & $\begin{array}{c}\text { b } \\
100,705 \\
100,260 \\
112,806 \\
110,318 \\
b \\
b \\
--\end{array}$ & $\begin{array}{c}b \\
745,812 \\
884,733 \\
886,748 \\
873,381 \\
950,585 \\
1,149,545 \\
440,080\end{array}$ & $\begin{array}{r}11,670,139 \\
10,901,973 \\
7,709,024 \\
7,649,434 \\
5,096,321 \\
4,497,473 \\
3,916,421 \\
2,851,474\end{array}$ \\
\hline Pellets & $\begin{array}{l}1973 \\
1974 \\
1975 \\
19 / 6 \\
1977 \\
1978 \\
1979 \\
1980\end{array}$ & $\begin{array}{l}56,031,439 \\
52,944,435 \\
53,089,020 \\
55,340,025 \\
37,478,248 \\
68,251,543 \\
73,712,806 \\
58,831,261\end{array}$ & $\begin{array}{l}b \\
b \\
b \\
b \\
b \\
-- \\
-- \\
--\end{array}$ & $\begin{array}{c}2,673,189 \\
\text { b } \\
\text { b } \\
\text { b } \\
\text { b } \\
954,758 \\
751,994 \\
1,276,646\end{array}$ & $\begin{array}{c}b \\
3,996,066 \\
3,411,312 \\
3,475,261 \\
3,459,088 \\
3,360,993 \\
3,551,601 \\
2,703,249\end{array}$ & $\begin{array}{l}63,935,447 \\
60,050,133 \\
59,865,167 \\
62,155,361 \\
43,460,566 \\
72,567,294 \\
78,016,401 \\
62,811,156\end{array}$ \\
\hline \multicolumn{7}{|l|}{ Total } \\
\hline Sh1pments & $\begin{array}{l}1973 \\
1974 \\
1975 \\
1976 \\
1977 \\
1978 \\
1979 \\
1980\end{array}$ & $\begin{array}{l}76,280,787 \\
72,194,123 \\
61,173,979 \\
64,927,713 \\
43,239,384 \\
74,307,299 \\
77,836,884 \\
61,536,060\end{array}$ & $\begin{array}{r}2,367,465 \\
2,365,704 \\
1,888,064 \\
2,099,251 \\
1,587,230 \\
421,380 \\
330,214 \\
300,851\end{array}$ & $\begin{array}{l}3,861,552 \\
2,818,595 \\
3,222,157 \\
3,151,907 \\
2,771,649 \\
1,301,131 \\
1,285,138 \\
1,904,549\end{array}$ & $\begin{array}{l}8,328,925 \\
7,496,753 \\
6,398,587 \\
6,547,383 \\
6,717,589 \\
6,981,612 \\
6,600,667 \\
4,785,548\end{array}$ & $\begin{array}{l}90,838,729 \\
84,875,175 \\
75,682,787 \\
76,726,254 \\
54,315,852 \\
82,611,422 \\
86,052,903 \\
68,527,008\end{array}$ \\
\hline
\end{tabular}

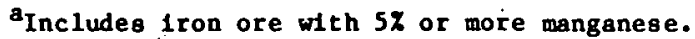

Wot shown to avold use of Individual company data.

Source: Ref. 44. 


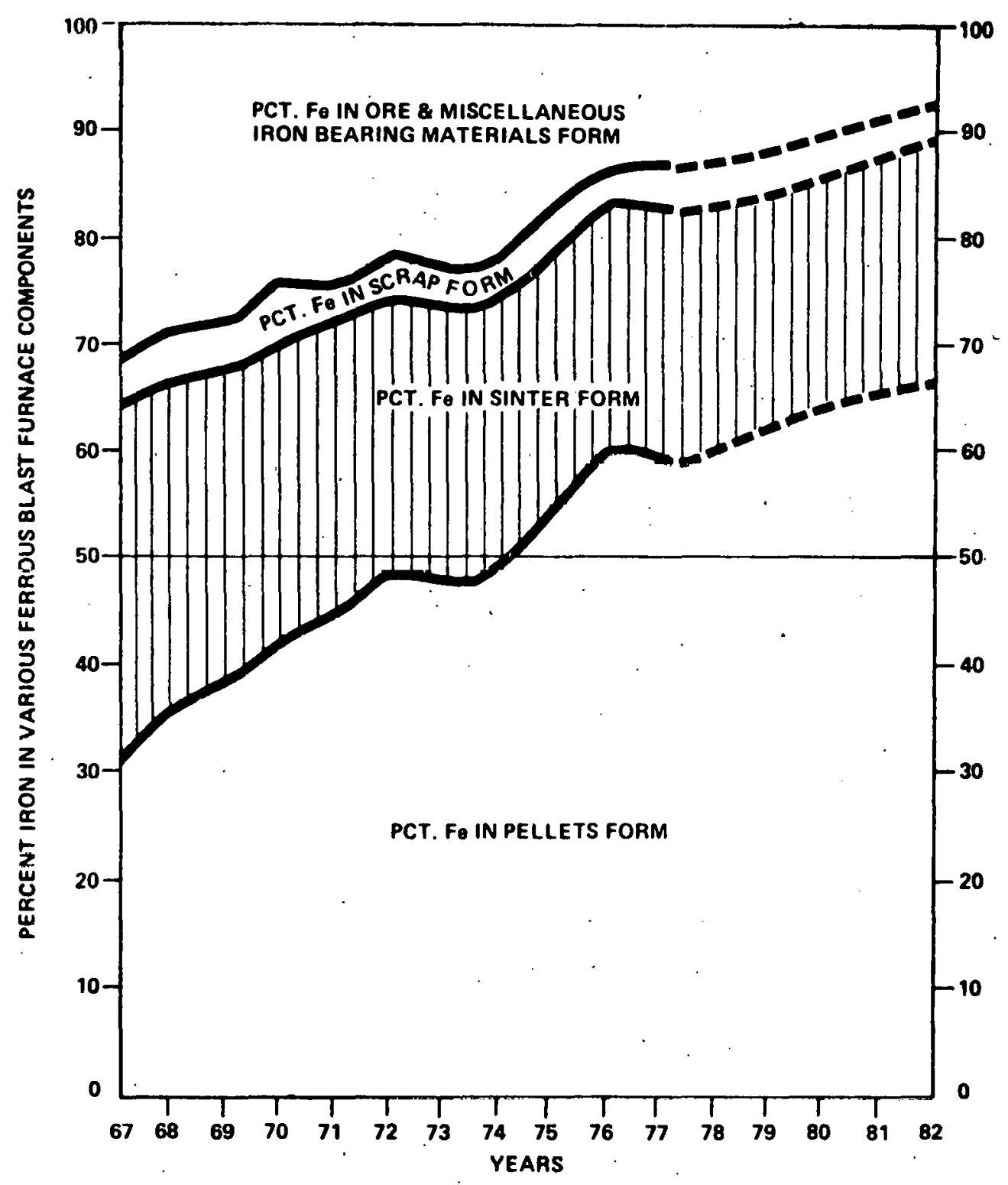

Fig. 4.3 Proportioning of Iron in Different Iron-bearing Materials in U.S. Blast Furnaces (Source: Ref. 45)

\subsection{CRUSHING, CONCENTRATION, AND PELLETIZATION}

Further processing of direct-shipping ores uses very little energy, since only crushing, screening, and washing are required to remove clay and sand. 29 Estimates range from $0.05 \times 10^{6} \mathrm{Btu} / \mathrm{ton}$ to $0.08 \times 10^{6} \mathrm{Btu} / \mathrm{ton}$. Since ore from this source is small ( $10 \%$ of domestic production) and on the decline (down two-thirds in the last 10 years), no further consideration will be given to 1 t. 44

Table 4.5 shows that pellet production, on the other hand, is very energy-intensive, r. ranging from $1.5 \times 10^{6}$ Btu to $2.3 \times 10^{6}$ Btu per ton of 
Table 4.4 Consumption of Iron Ore at U.S. Iron and Steel Plants, 1971-1980 (10 $10^{3}$ gross tons)

\begin{tabular}{|c|c|c|c|c|c|c|}
\hline \multirow[b]{2}{*}{ Year } & \multicolumn{2}{|c|}{ United States Ores } & \multicolumn{2}{|c|}{ Canadian Ores } & \multirow[b]{2}{*}{$\begin{array}{l}\text { Foreign } \\
\text { Ores }\end{array}$} & \multirow[b]{2}{*}{ Total } \\
\hline & $\begin{array}{l}\text { Great } \\
\text { Lakes }\end{array}$ & Other & $\begin{array}{l}\text { Great } \\
\text { Lakes }\end{array}$ & Other & & \\
\hline $\begin{array}{l}1971 \\
1972 \\
1973 \\
1974 \\
1975 \\
1976 \\
1977 \\
1978 \\
1979 \\
1980\end{array}$ & $\begin{array}{l}59,547 \\
68,782 \\
76,603 \\
70,978 \\
60,061 \\
63,864 \\
57,663 \\
64,617 \\
66,080 \\
53,985\end{array}$ & $\begin{array}{r}13,548 \\
13,075 \\
13,773 \\
12,402 \\
10,777 \\
11,267 \\
13,217 \\
10,090 \\
9,872 \\
8,297 .\end{array}$ & $\begin{array}{l}3,828 \\
3,871 \\
4,251 \\
3,345 \\
2,694 \\
4,672 \\
4,457 \\
3,379 \\
2,228 \\
1,368\end{array}$ & $\begin{array}{l}14,894 \\
16,480 \\
17,992 \\
15,608 \\
12,731 \\
18,185 \\
16,985 \\
18,734 \\
20,843 \\
15,912\end{array}$ & $\begin{array}{r}17,149 \\
17,729 \\
24,454 \\
26,744 \\
19,967 \\
16,335 \\
16,140 \\
19,494 \\
15,991 \\
9,835\end{array}$ & $\begin{array}{r}108,966 \\
119,937 \\
137,073 \\
129,077 \\
106,230 \\
114,323 \\
108,462 \\
116,304 \\
115,014 \\
89,397\end{array}$ \\
\hline
\end{tabular}

Source: Ref. 44 .

pellets, depending primarily on the amount of magnetite in the ore. The higher the magnetite content, the lower is the energy use per ton, because of (a) the lower energy requirements for magnetic separation; and (b) the generation of heat when magnetite oxidizes to hematite. The production of pellets from taconite consumes significant amounts of energy in the form of electricity and hydrocarbons, and is the major reason why iron ore mining used almost as much energy in $1977\left(78.9 \times 10^{12} \text { Btu }\right)^{46}$ as steelmaking did in the previous year $\left(94 \times 10^{12} \mathrm{Btu}\right) .47$ As Fig. 4.1 illustrates, the process has three steps: crushing, separating or concentrating, and induration.

Since taconite is a very tough material, the crushing step requires considerable electrical energy to run the equipment. Concentration is done by gravity, flotation, or magnetic separation processes. The range of estimates in Table 4.5 is due almost completely to the range of electrical energy use in the references, where the estimates were $50 \mathrm{kWh}, 75 \mathrm{kWh}, 105 \mathrm{kWh}$; and $150 \mathrm{kWh}$ per ton of taconte. Such variation can be explained by differences in the ore silicon content, age of the equipment, type of grinding process, etc., although there is some evidence that the estimates lower than $200 \mathrm{kWh} / \mathrm{ton}$ ignored the large amount of electricity used in the magnetic separation process. 48

There is much interest in energy-conserving possibilities for industrial comminution (i.e., crushing and grinding). A recent NRC publication estimates that comminution consumed between $1 \%$ and $2 \%$ of the nation's electric power production in 1978, and is "both energy intensive and inefficient."49 
Table 4..5 Direct Energy Intensities in Iron Ore Mining and Concentration ${ }^{a}\left(10^{6} \mathrm{Bt} u / t\right.$ on of end product)

\begin{tabular}{|c|c|c|c|c|c|c|c|c|c|}
\hline \multirow{2}{*}{$\begin{array}{l}\text { Reference, } \\
\text { Base Year } \\
\text { for Data }\end{array}$} & \multicolumn{4}{|c|}{ Concentrates } & \multicolumn{5}{|c|}{ Pellets } \\
\hline & Mining & $\begin{array}{l}\text { Concen- } \\
\text { tration }\end{array}$ & Other & Total & M1ning & $\begin{array}{l}\text { Concen- } \\
\text { tration } \\
\end{array}$ & $\begin{array}{l}\text { Indu- } \\
\text { ration }\end{array}$ & other & Total \\
\hline $\begin{array}{l}\operatorname{Ref} .38,1977^{b} \\
\operatorname{Ref} .50,1975 \\
\operatorname{Ref.} 30,1978\end{array}$ & $\begin{array}{l}0.184 \\
0.142^{d} \\
0.14^{\mathrm{e}}\end{array}$ & $\begin{array}{l}0.04 \\
d \\
0.08\end{array}$ & $\begin{array}{l}0.01 \\
0.032 \\
-\end{array}$ & $\begin{array}{l}0.234^{c} \\
0.174 \\
0.22\end{array}$ & $\begin{array}{l}0.165 \\
0.21 \mathrm{f}\end{array}$ & $\begin{array}{l}0.83 \\
1.317 \\
0.518\end{array}$ & $\begin{array}{l}0.885 \\
0.5^{\mathrm{g}} \\
{ }^{\mathrm{h}}\end{array}$ & $\begin{array}{l}0.04 \\
0.189 \\
0.252\end{array}$ & $\begin{array}{l}2.02^{\mathrm{c}} \\
1.51 \\
1.48 \mathrm{~g} \\
1.99^{\mathrm{h}}\end{array}$ \\
\hline $\begin{array}{l}\text { Ref. } 39,1976 \\
\text { Ref. } 29,1975^{b} \\
\operatorname{Ref.} 46 ; 1977\end{array}$ & & . & & 0.31 & 0.606 & 1.145 & 0.561 & - & $\begin{array}{l}1.59 \\
2.31 \\
2.1 .3^{a}\end{array}$ \\
\hline $\begin{array}{l}\text { Ref. } 37,1980 \\
\operatorname{Ref} .51,1981\end{array}$ & & & . & 0.28 & & & $\begin{array}{l}0.556^{f} \\
1.15^{g} \\
0.395^{1}\end{array}$ & 0.25 & \\
\hline Ref. 52, 1979 & . & & & & . & & $\begin{array}{l}0.591 \mathrm{j} \\
0.604^{k} \\
0.607^{1}\end{array}$ & $\begin{array}{l}0.22 \\
0.19 \\
0.26\end{array}$ & \\
\hline $\operatorname{Ref} .49,1977$ & & . & & & . & $1.1^{\mathrm{m}}$ & & & \\
\hline
\end{tabular}

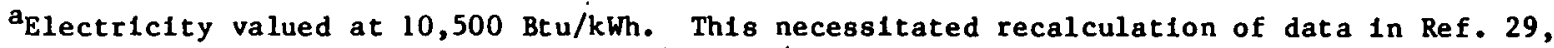
which were based on electricity at $3,412 \mathrm{Btu} / \mathrm{kWh}$.

${ }^{b}$ Study results 1 n Refs. 29 and 38 are for direct and Indirect energy intensities combined. Transportation energy intensities vary between these two studies because of different assumptions about mileage and energy intensity per mile.

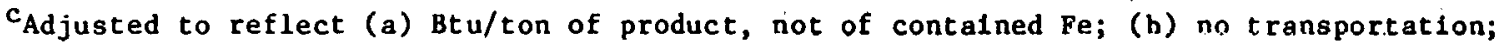
(c) direct energy use except for electricity. If direct and indirect energy intensities were both counted, iron ore and pellet totals would be 0.34 and 2.53 , respectively.

$\mathrm{d}_{\mathrm{M} 1 \mathrm{ning}}$ and concentration summed together yleld $0.142 \times 10^{6} \mathrm{Btu} / \mathrm{ton}$.

eAssumes two tons of crude ore per ton of direct shipping ore.

fAssumes three cons of tacontte per ton of pellets.

$\mathrm{BFe}_{3} \mathrm{O}_{4}$

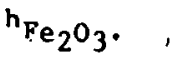

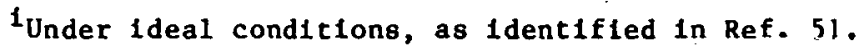

Jior shaft induration equipment.

For grate-kiln induration equipment.

$1_{\text {For traveling-grate induration equipment. }}$

mor magnets. 
The report points out that modifying equipment with existing technology (automatic control, improved sizing and classification, closed circuit grinding, use of additives) could reduce energy consumption by 9 billion $\mathrm{kWh}(\mathrm{e})$ in five years, while new technologies could trim an additional 15 billion $\mathrm{kWh}(\mathrm{e})$ in the longer term. Despite this interest, no specific energyconserving technologies were identified in the report for iron ore crushing; however, new technologies are being developed that will achieve more efficient blast furnace processing of ores with high iron content. They include cationic silica removal, floculation of iron oxide to lower $\mathrm{Fe}$ loss, and conversion of nonmagnetic to magnetic ore to allow magnetic beneficiation. 37

The mixture of moist clay, hydrocarbons, and ore produced during the concentration step is then fired and heat-hardened in ignition furnaces. Table 4.5 shows that energy use in the induration step (i.e., pelletizing at $2000^{\circ} \mathrm{F}$, usually using hydrocarbons) ranges from $5 \times 10^{6} \mathrm{Btu} /$ tion to $1.15 \times 10^{6}$ $\mathrm{Btu} / \mathrm{ton}$, depending on the amount of magnetite in the ore and, to a large extent, on the type of induration equipment -- shaft, grate kiln, or traveling grate. Since hydrocarbons -- mainly fuel oil and natural gas -- have been used in the induration process, much effort has been devoted to conservation and fuel-switching opportunities.

Several firms report great success in reducing the amount of energy used in induration. The Erie Mining Co.'s plants in Aurora, Minnesota, recently received the National Energy Watch Award from the Edison Electric Institute for reducing energy consumption per ton by $20 \%$. Hibbing Taconite Corp reports \& $38 \%$ reduction in consumption at its plants, to $300,000 \mathrm{Btu} /$ ton, 53 which is we11 below the 500,000-600,000 Btu/ton average in Table 4.5 and very close to the level under ideal conditions, as identified by Wakeman and Frans. 51 Ideal conditions would include nonreactive feed, no fixed heat losses, input and output air and solids temperature at $77^{\circ} \mathrm{F}$, and $10 \%$ moisture content for the mixture of raw material.53 Energy consumption is higher at older plants, since they lack the heat recuperation facilities that are part of all modern plants. However, most old plants can and probably will be retrofitted to recover heat from the first cooling zone, since 1981 fuel prices make the investment cost-effective.

Turning to fuel substitution for the hydrocarbons now used, since $85 \%$ of U.S. pellet capacity shown in Table 4.6 is in Minnesota and Michigan, the use of western coal as a substitute fuel is a logical possibility. Two alternatives are direct firing of the kiln by processed coal, and conversion of coal to coal gas for use. At least four of the largest pelletizing operations, representing over $50 \%$ of U.S. capacity, have taken steps towards direct firing of coal (Inland, Hibbing, U.S. Steel) or coal gasification (Erie). Operating problems still hamper these processes, and Inland's straight-grate system is still not working. Suppliers of both the grate-kiln system (AllisChalmers) and the traveling-grate system (Dravo) have modified their processes to insure that ash buildup the major impediment to switching to coal, is held within acceptable bounds. 30 However, the experience at some plants using coal firing indicates that ash from coal may not be a problem. 
Table 4.6 U.S. Pellet P1ants

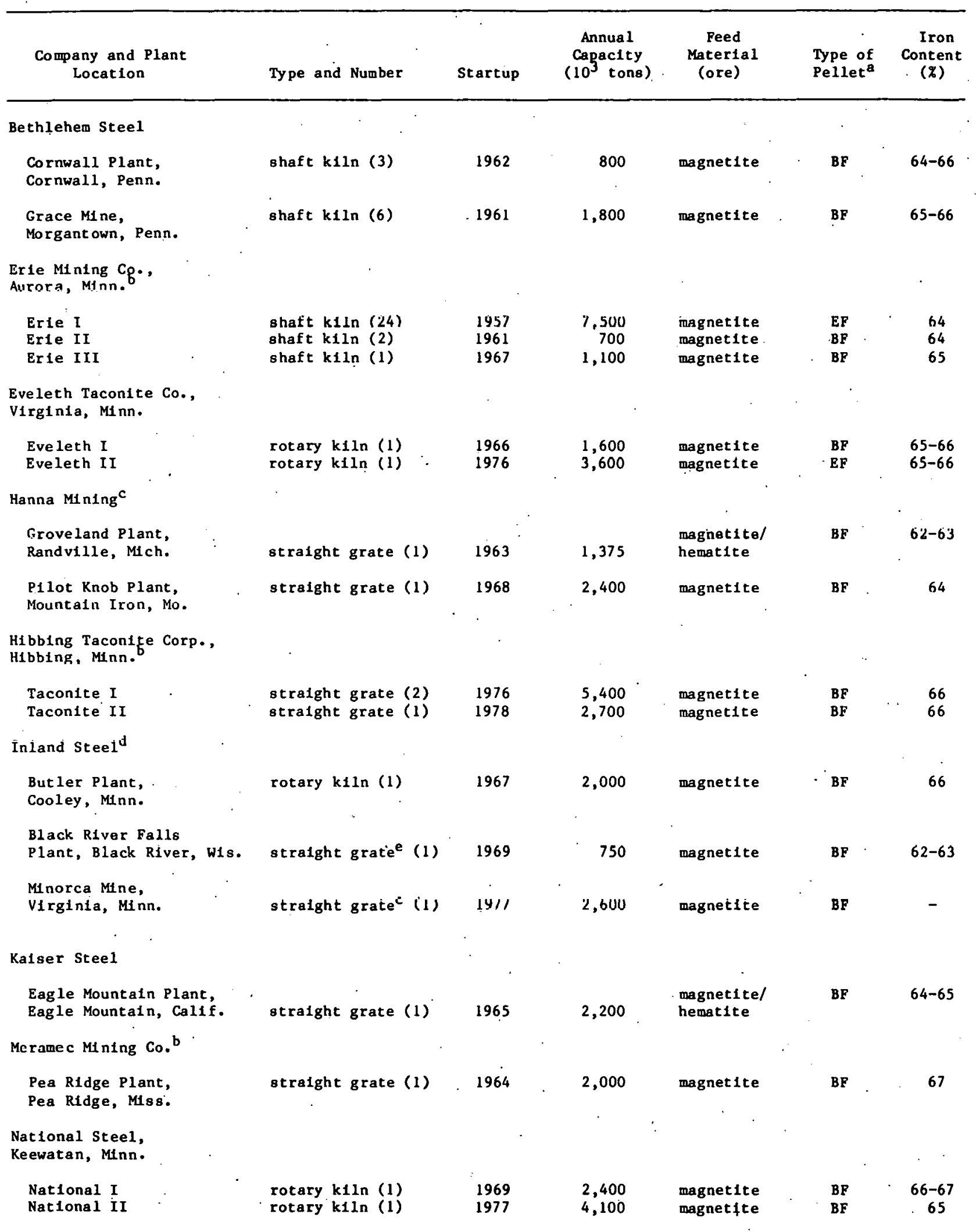


Table 4.6 (Cont'd)

\begin{tabular}{|c|c|c|c|c|c|c|}
\hline $\begin{array}{c}\text { Company and Plant } \\
\text { Location }\end{array}$ & Type and Number & Startup & $\begin{array}{c}\text { Annual } \\
\text { Capacity } \\
\left(10^{3} \text { tons }\right)\end{array}$ & $\begin{array}{l}\text { Feed } \\
\text { Mater1al } \\
\text { (ore) }\end{array}$ & $\begin{array}{l}\text { Type of } \\
\text { Pellet }\end{array}$ & $\begin{array}{c}\text { Iron } \\
\text { Content } \\
(x)\end{array}$ \\
\hline \multicolumn{7}{|l|}{$\begin{array}{l}\text { Reserve Mining, } \\
\text { Silver Bay, Minn.f }\end{array}$} \\
\hline $\begin{array}{l}\text { Reserve I } \\
\text { Reserve II }\end{array}$ & $\begin{array}{l}\text { stralght grate }(6) \\
\text { straight grate }(2)\end{array}$ & $\begin{array}{l}1955 \\
1963\end{array}$ & $\begin{array}{l}5,500 \\
3,000\end{array}$ & $\begin{array}{l}\text { magnetite } \\
\text { magnetite }\end{array}$ & $\begin{array}{l}\text { BF } \\
\text { BF }\end{array}$ & $\begin{array}{l}62-63 \\
62-63\end{array}$ \\
\hline \multicolumn{7}{|l|}{ United States Steel. } \\
\hline $\begin{array}{l}\text { Atlantic C1ty Plant, } \\
\text { Lander, Wyo. }\end{array}$ & straight grate $(2)$ & 1962 & 1,500 & magnetite & $\mathbf{B F}$ & $63-64$ \\
\hline \multicolumn{7}{|l|}{ Mountain Iron, Minn. } \\
\hline $\begin{array}{l}\text { Mintac I } \\
\text { Mintac II } \\
\text { Mintac III }\end{array}$ & $\begin{array}{l}\text { rotary k11n (3) } \\
\text { rotary k1ln (2) } \\
\text { rotary k1ln (2) }\end{array}$ & $\begin{array}{l}1967 \\
1972 \\
1977\end{array}$ & $\begin{array}{l}4,500 \\
6,000 \\
6,000\end{array}$ & $\begin{array}{l}\text { magnetite } \\
\text { magnet1te } \\
\text { magnet1te }\end{array}$ & $\begin{array}{l}\text { BF } \\
\text { BF } \\
\text { BF }\end{array}$ & $\begin{array}{l}65 \\
65 \\
65\end{array}$ \\
\hline local & & & 71,525 & & & \\
\hline
\end{tabular}

$a_{B F}=$ blast furnace; $E F=$ electric furnace.

escrubbers Installed for pollution control.

bartially owned by Bethlehem steel.

$f_{\text {Jolnt ly owned by Armco, Inc., and Republic }}$

CDivision of National Steel.

dPartial.1.y owned by Hasca Pellet Co.

Source: Ref. 55, p. 17 .

Because pre-1965 facilities with shaft furnaces will encounter difficulties with direct firing of coal, they will likely turn to on-site coal gasification, as Erie has, for alternate sources of fuel. According to one source, the process economics look quite favorable, since the cost of fuel gas per long ton of pellet to achieve an $8 \%$ return on investment is $\$ 1.81$ for the shaft furnace, with coal (western unit train) at $\$ 20$ per delivered ton. 52 The conventional shaft furnace uses roughly 600,000 Btu of natural gas per ton (400,000-450,000 Btu with heat recuperators). With natural gas selling at $\$ 2.68 / 10^{3} \mathrm{ft}^{3}$, the cost of conventional fuel would be $\$ 1.56 .55$ However, another study indicates that the cost would be significantly higher ( $\$ 4.80 /$ long ton) if a $15 \%$ return on investment is used. If natural gas increases in price, on-site gasification could soon become economical. What makes the onsite system so attractive is that the low-Btu gas is delivered to the pellet plant at $1000^{\circ} \mathrm{F}$; the kiln takes full advantage of the latent heat of the coal gas. A problem is that there are few uses, outside the kiln itself, for the hot low-Btu gases produced by the process.

In summary, the prospects look bright both for energy conservation and switching to coal for the pelletizing process; substantial reductions in total Btu and natural gas use per ton of pellets are likely in the near future. 


\section{SINTERING PLANT}

Figure 5.1 gives the materlals and energy flows for the blast furnace area, including the coke ovens, sinter plant, and blast furnace (Including stoves) for 1980. The amounts are based primarily on AISI data, except for the data on tars, 1ight o11s, and coke breeze, which are taken from a recent DOE Energy Data Report. This chapter discusses sinter production; coke oven and blast furnace processes are discussed in the following two chapters.

The sintering plant provides a means of recycling many of the 1ronbearing fines generated by lronmaking and steelmaking. Materials such as scale, sludge, and slag are added to ore fines and agglomerated into a suitable material. Flux, in the form of dolomite or limestone, is added to the sinter burden and calcined during the process, decreasing the energy requirements of the blast furnace process. Blast furnace slag is not recycled through the sinter plant, but is sold to slag scrap processors who convert. the slag into salable products. Electric arc sludge and slag are not normally included in sintering burdens because of tramp impurities. 15

The sinter, usually 50-60\% Fe, 1s easily, reducible, since its high surface-to-volume ratio permits high gas/solid contact. It is blended and sized prior to feeding onto the grate. To prevent ascending gas in the blast furnace from blowing it out of the stack, the blend is adjusted until it is strong enough to resist being compressed into an impervious layer in the furnace. Fuel for the process is provided by the metal-bearing raw material itself, plus coal and coke breeze. As Fig. 5.2 1llustrates, the process takes place on a traveling grate that carries the sinter, which is carefully bedded to insure consistent quality. The fuel is 1 gnited and the flame is drawn down through the sinter by alr suction windboxes; the process is complete when burn-through takes place at the sintering temperature of $2500^{\circ} \mathrm{F}$. The sinter is then cooled either on- or off-strand, sized to less than one-half Inch, and fed into the blast furnace.

Several U.S. plants have experimentally recycled sinter gas to conserve the sensible heat and reduce environmental problems; there is some question about the cost-effectiveness of this process. No plant is now doing this recycling, since even though it saves $3 \%$ of the energy $\left(0.059 \times 10^{6} \mathrm{Btu} /\right.$ ton), it replaces an inexpensive energy source (coke breeze) by an expensive one (electricity to run the recirculation fans). 56

Table 5.1 shows the materials flows into sintering plants. Iron in the form of sinter fell steadily from 35\% of the blast furnace charge in 1967 to about $25 \%$ in 1972 , and has remained roughly constant since then. 46 Sinter plant capacity has remalned near 45 million tons for some time, with nearly $25 \%$ of the plants over 35 years old. 57

One source predicts little possibility of this capacity increasing, since the high-grade fines sultable for sintering (principally hematite from 


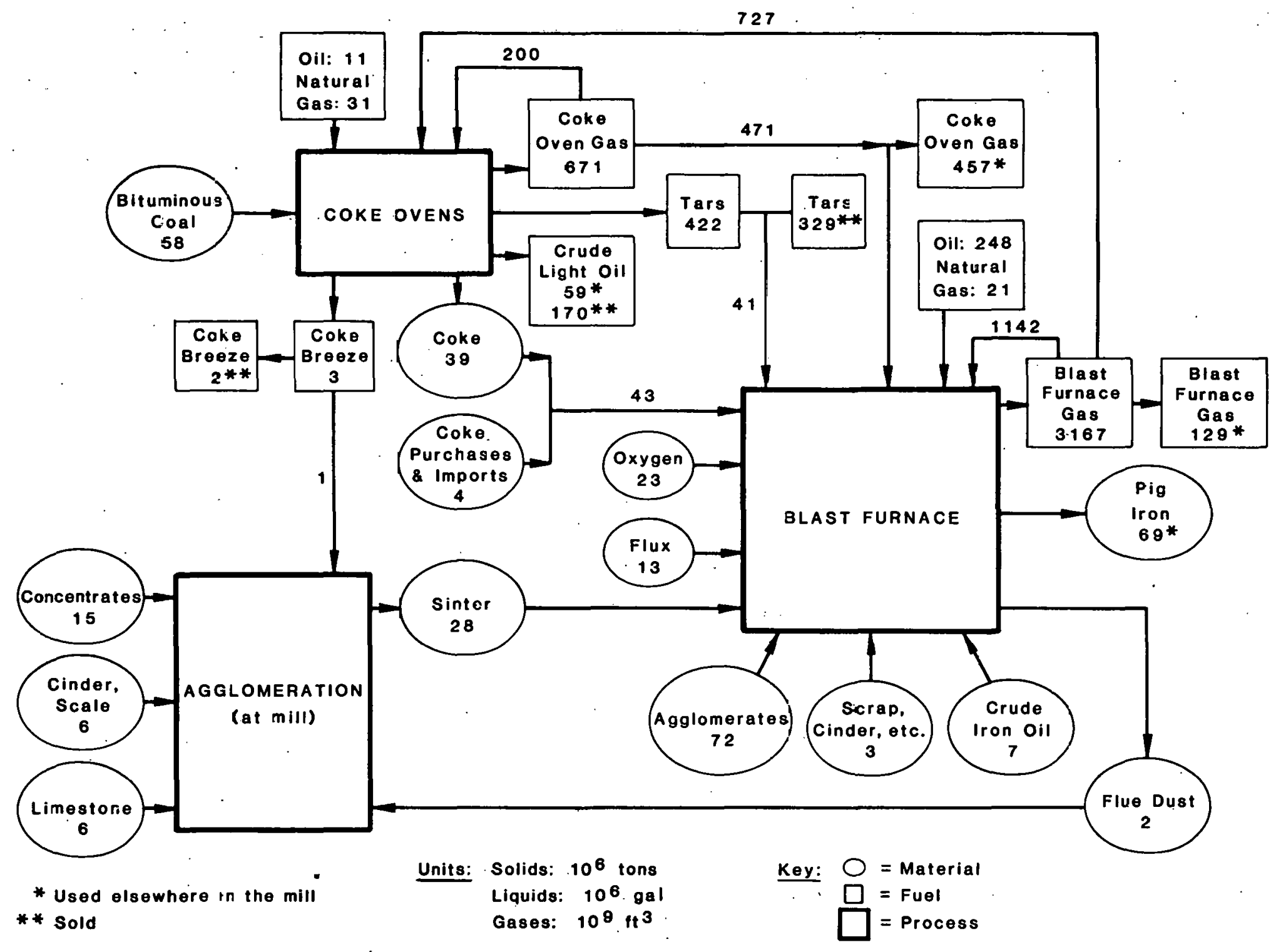

Fig. 5.1 Materials Flows in the Blast Furnace Area, 1980 (Source: Refs. 1, 28) 


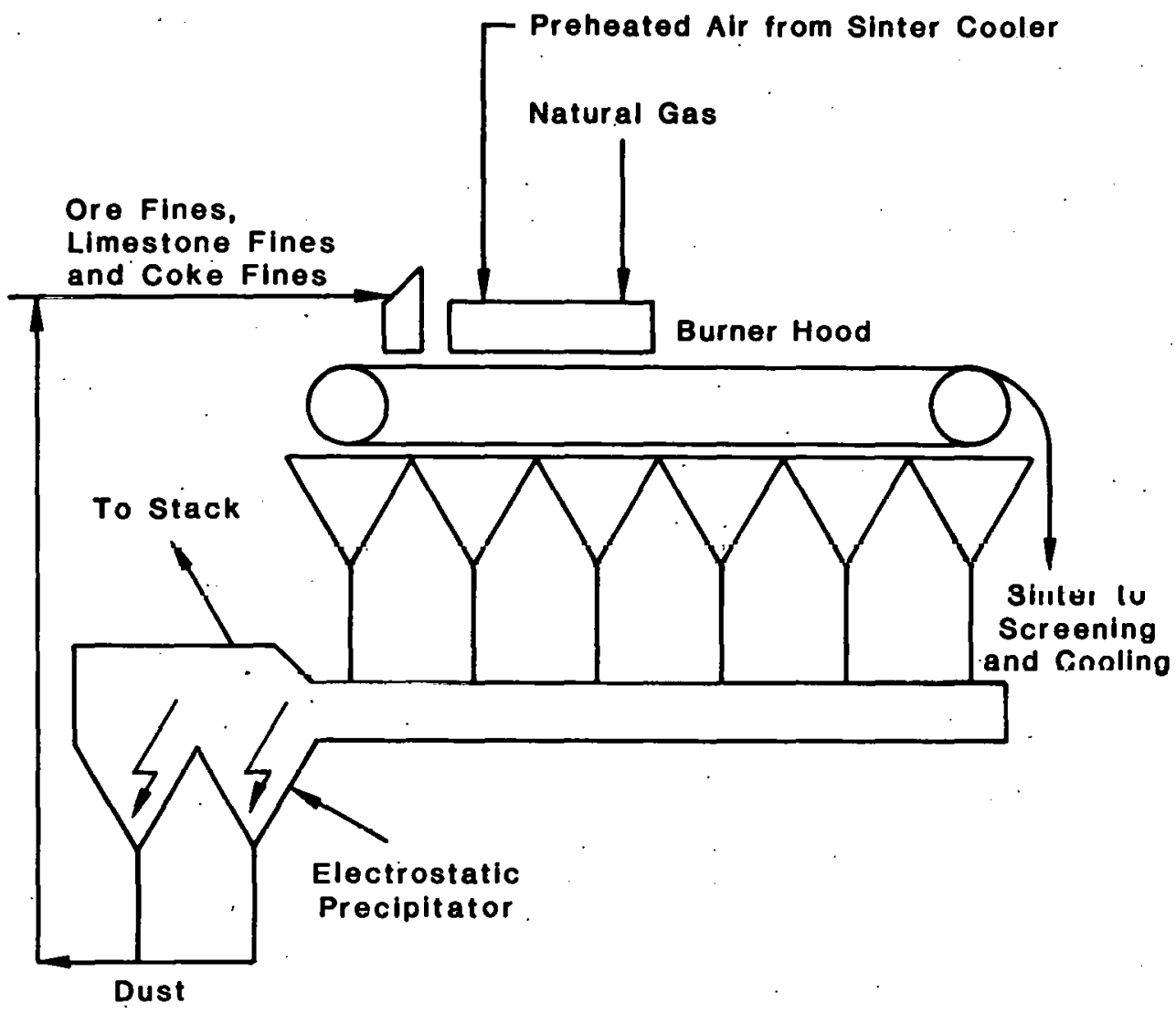

Fig. 5.2 Typical Sintering Machine

Quebec, Brazil, and Venezuela) are beling replaced by lower-grade ores (taconite) suitable for pelletizing. 46 This development prompted renewed interest in the mid-1970s in binderless (1.e., no paste) hot $\left(1800^{\circ} \mathrm{F}\right.$ ) briquetting as a substitute for agglomerating steel mill wastes in the absence of such fines. 58 The process drastically reduces energy consumption since it does not require complete combustion of the nonvolatile combustible matter as does the sinter process. The excess remains in the product, allowing the energy requirements for the blast furnace to be reduced.

The Japanese have been exploring direct reduction of blast furnace and BOF wastes; ${ }^{59}$ significant energy savings over comparable processes have been reported. Japan is the only country currently emphasizing iron fines recycling; approximately $70 \%$ of 1 ts residues are recycled. 6 There will 11 kely be a resurgence of sinter plants in response to the increasing values of the carbon and iron content that would otherwise be wasted. Forelgn ore fines are plentiful, and lmproved blending and bedding of the sinter w111 increase the productivity of the process. Sinter is desirable in a blast furnace, since full pellet charges increase wall temperature and reduce furnace life.

Energy intensities for sinter plants show wide variation due to the large variation in input mixes encountered in the waste recycling and recovery 
Table 5.1 Sinter Production, 1973-1980 ( $10^{3}$ net tons)

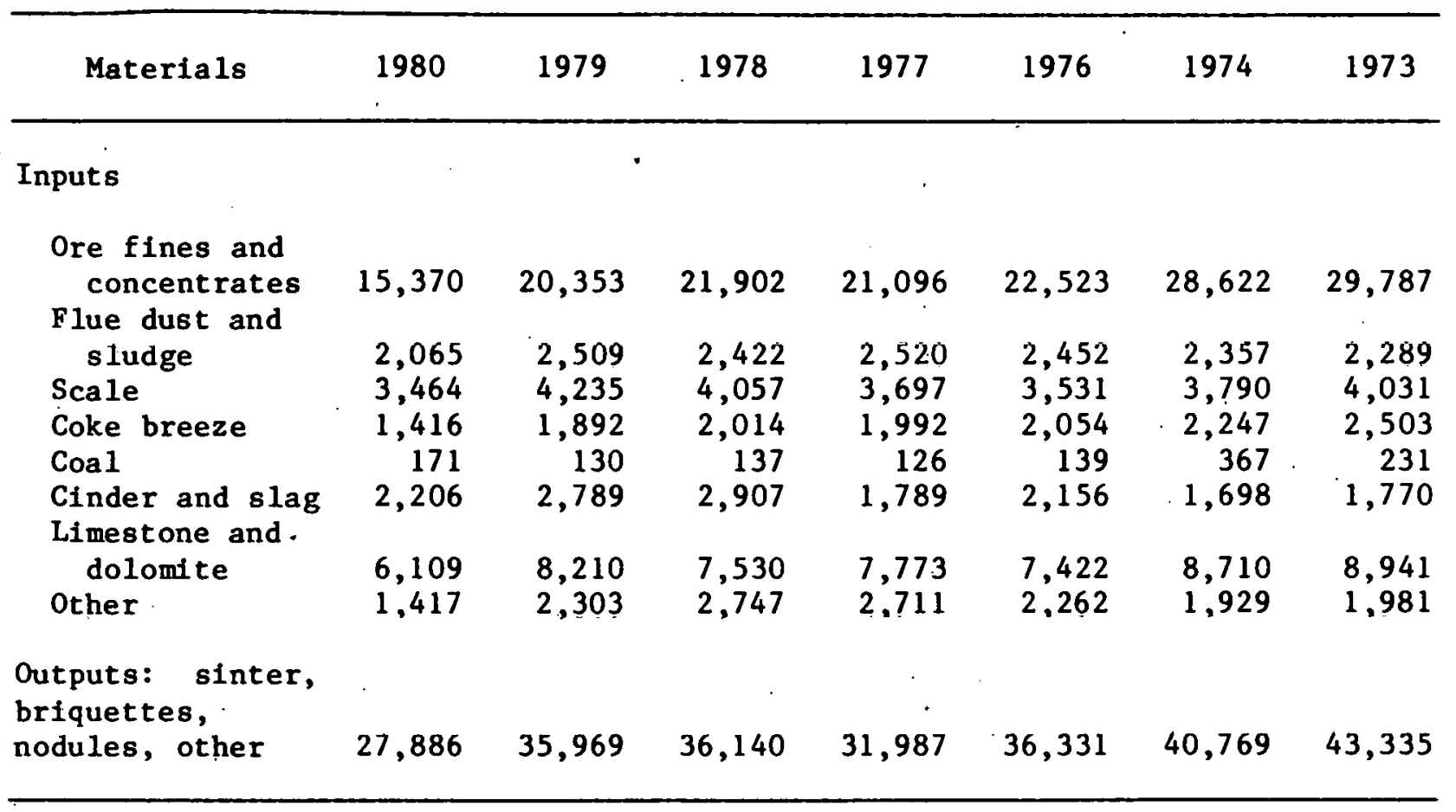

Source: Ref. 60, except ore fines, whtch are from Ref. 45.

process. Table 5.2 gives the estimates from the various sources utilized in this study. The hot briquetting energy intensity is included for comparison. At least one source thinks any substantial energy savings in the sintering process to be unlikely, although alternate technologies (hot briquetting, etc.) would save energy if substituted. 30 Another report indicates that injection of steam produced by partial recovery of the sensible heat of sinter waste gases into the balling drum of the sinter plant has reduced fuel consumption by $8.4 \% .61$

According to an OTA study, current capital shortages and slack capacity make it unlikely that steel companies will show much interest in what amounts to waste recycling; most likely, slag scrap recoverers will diversify into the sinter business. ${ }^{6}$ Most industry sources disagree, and expect a resurgence in sintering as the value of the contained iron continues to rise. 
Table 5.2 Energy Intensities in the Production of Iron Ore Sinter

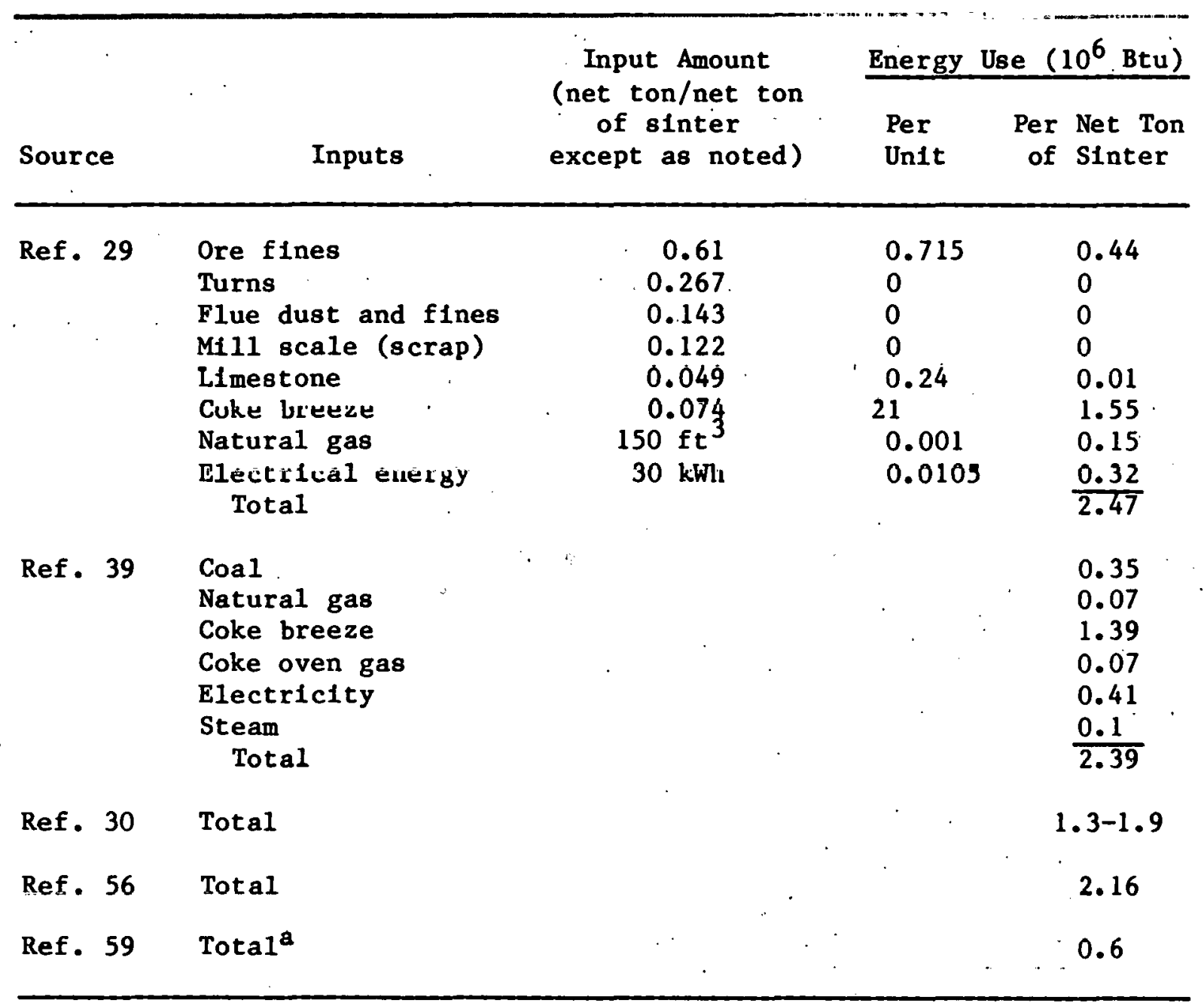

a For nonsinter process of hot briquetting. 


\section{COKE PRODUCTION}

\subsection{COKE AND ITS BY-PRODUCTS}

\subsubsection{Characteristics of Coke}

The destructive distillation of a blend of bituminous coals in coke ovens at $1650^{\circ}-2000^{\circ} \mathrm{F}$ produces a carbonaceous residue known as coke. Coke is the primary fuel for blast furnaces, which produce the iron for steelmaking furnaces.

In the blast furnace, a chemical agent is needed to reduce the oxides of 1ron; this agent is carbon, provided by coke. Coke production requires an expensive low-sulfur bituminous coking coal. The optimal blend of coals, as reported by Thermo Electron Corp., is $60 \%$ high-volatile coal and $40 \%$ lowvolatile coal, 39 although ratios of $70 / 30$ to $80 / 20$ are preferred by some to 1imit expansion. At present the average $\mathrm{mix}$ is $65 \% \mathrm{high}-, 13 \%$ medium-, and $22 \%$ low-volatile coal. If only high-volatile coal were used, the coke would have a porous, weak form rather than the firm, cellular form desired, which is not obtainable from all bituminous coals.

Other desirable properties of coking or metallurgical-grade coals are a low ash content (no more than $8 \%$ ), low sulfur content (less than 1\%), and low alkall content, particularly in western coals. Use of coal with high ash and sulfur contents results in added slag in the blast furnace, increased expenditures for coke, and decreased production. However, the integrated steel mills are facing competition from the utilities for low-sulfur coal because of the scarcity of natural gas and the environmental protection laws.

\section{1 .2 Production Process}

Coke 18 made as follows. A preparation facllity recelves the varlous coals sultable for coking, grinds them, and blends the high-, medium-, and low-volatile coals in the requisite proportions. The crushed coal is transferred to the plant site and charged into by-product coke slot ovens (so named because they have facllities for recovering by-products such as light ofls, tar, ammoula, and coke oven gas). Combustion afr is heated in.regenerators and mixed with infected and recycled fuels ( $40 \%$ of coke oven gas is recycled, and blast furnace gas is used for underfiring) for burning in the combustion chamber. Under normal operating conditions, the charge 1s heated for 16 to 20 hours ( 14 or 1 ess with preheated coal); then the coke 18 forced into waiting cars, where it is water-quenched to prevent combustion. A significant portion of the sensible heat is lost here $\left(1.4 \times 10^{6} \mathrm{Btu} / \mathrm{t}\right.$ on of coke) and could be partly recovered. After cooling, the coke is crushed and screened. Most of it 18 then transported to the blast furnace, and the remaining coke dust (either buckwheat or coke breeze) 18 conveyed to the reclamation plant and 
elther utilized as fuel in the sintering operation or sold (particularly buckwheat).

Figure 6.1 depicts a typical coke oven; the outputs are: (1) coke, (2) coke oven gas, consisting of a mixture of $\mathrm{H}_{2}, \mathrm{CO}, \mathrm{C}_{2} \mathrm{H}_{4}$, and $\mathrm{CH}_{4}$ with a heating value of $500 \mathrm{Btu} / \mathrm{ft}^{3}$, (3) coke breeze, (4) tars, and (5) $11 \mathrm{ght}$ olls and ammonia as sulfate. (Since raw coke oven gas usually contains ammonia, it is scrubbed with sulfurlc acld, forming ammonium sulfate.)

Calculating the production and disposition of coke and coke oven byproducts Involves reconclling two separate sources of information: AISI data on member furnace plant consumption; and DOE production and consumption data (including merchant sales) on the U.S. coke industry, including merchant and furnace plants.

The data reported by AISI Include the total coal, coke oven gas, coke breeze, and tar and pltch consumed in the blast furnace, coke ovens, and elsewhere. The DOE data include both production and consumption of these materials, as well as of.11ght olls and other minor products. For this report, an estimate of the energy value of coke oven products sold would be

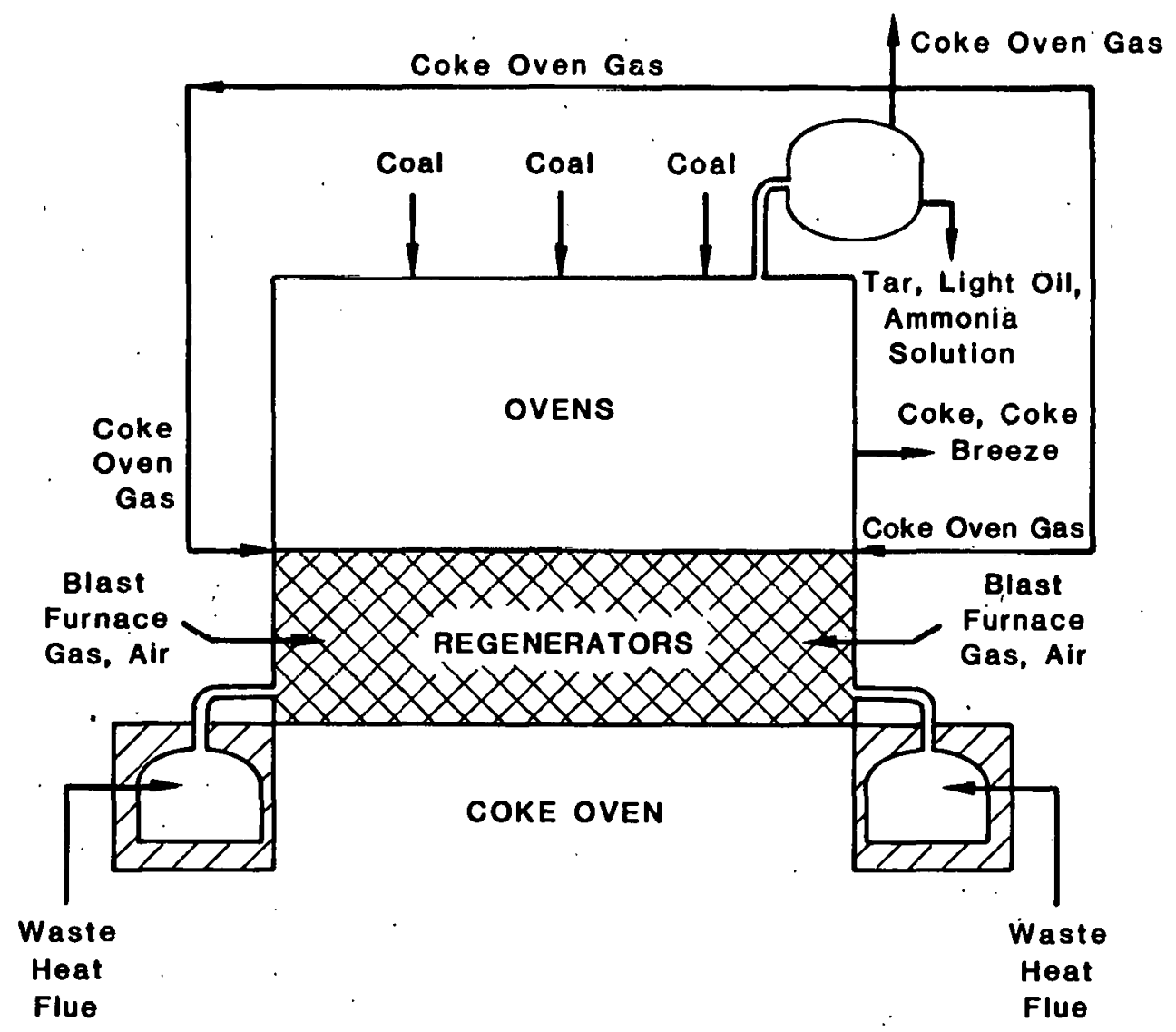

Fig. 6.1 Typical Coke Oven 
useful, so as not to charge the iron and steel industry for energy it does not utilize.

The DOE data also include furnace plant sales of coke breeze, coke oven gas, tar, and light oils. A comparison of furnace plant sales of tars, as reported by DOE, and AISI furnace plant consumption of breeze, tar and pitch, and coke oven gas make it clear that consumption should not be equated with production. Consequently, this study derives total production of coke oven by-products by summing AISI consumption and DOE sales data for tar, pitch, breeze, and coke oven gas; production and sales of light oils are from DOE data on ly.

As Fig. 5.1 indicated, the by-products can be recycled for internal use or sold. This is not a small enterprise; in 1979, steel firms' sales of coke by-products amounted to over $\$ 520$ million, or about $13 \%$ of the value of the coal consumed in coke production. 28 The energy equivalent of these sales is still small; Fig. 5.1 indicates that, even though $3 \%$ of the coke oven gas, $75 \%$ of the tars and light ofls, and $40 \%$ of the breeze are sold, the amount is less than $5 \%$ of the total energy available from the ovens.

Table 6.1 gives the geographic distribution of U.S. coke oven capacity, and Tables $6.2,6.3$, and 6.4 give the major materials flows for the production of coke in recent years.

\subsection{PROBLEMS FACING THE INDUSTRY}

A major problem facing the steel industry is the aging of U.S. coke ovens and their dwindling capacity; nearly $50 \%$ of the ovens are over 20 years old, and $25 \%$ are over 25 years old. The reason for this is that replacement costs are very high; a single by-product coke battery producing one million tons per year now costs well over $\$ 200$ million. 62 . Hogan and Koelbe indicate that in the period 1975 to 1978 , the industry retired 10.9 million tons of cukliy capaclty, almost $20 \%$ of the estimated 60-million ton capacity in 1975.63 (They predict another 5.3 million tons in capacity to be lost by 1985.) During the same period, coke imports rose from 1.8 million tons to 5.7 million tons (mostly from West Germany, where coke is considered a byproduct of gas production).64 While imports are a short-term solution to shortages, they can be expensive; during the world coke shortage of 1973-1974, the price of imported coke was $66 \%$ abuve the cost of production. 63

Dwindling capacity is not the only problem; domestic supplies of lowsulfur coal, although still plentiful, have been reduced to the point where future mining and processing will take place only at higher costs. Ninety percent of the 1 ow-sulfur bituminous and sub-bituminous coal reserves are not suitable for coking. Of the reserves that are suitable, $80 \%$ are in the West Virginia/Kentucky region. 64 
Table 6.1 Geographic Distribution of U.S. Coke Oven Cafacity

\begin{tabular}{|c|c|c|c|c|c|}
\hline States & $\begin{array}{l}\text { Number of } \\
\text { Plants }\end{array}$ & $\begin{array}{l}\text { Number of } \\
\text { Batteries }\end{array}$ & $\begin{array}{l}\text { Number of } \\
\text { Ovens }\end{array}$ & $\begin{array}{l}\text { Annual } \\
\text { Capactty } \\
\text { (tons) }\end{array}$ & $\begin{array}{l}\% \text { of } \\
\text { Total }\end{array}$ \\
\hline Alabama & 7 & 25 & 1,215 & $5,182,338$ & 9.02 \\
\hline $\begin{array}{l}\text { California, Colorado, Utah } \\
\text { Connect1cut, Maryland, } \\
\text { Massachusetts, New Jersey, }\end{array}$ & 3 & 14 & 710 & $3.273,472$ & 5.70 \\
\hline New York & 4 & 18 & 1,074 & $4.987,013$ & 8.68 \\
\hline Illinols & 4 & 7 & 326 & $1,807,560$ & 3.14 \\
\hline Indiana & 6 & 25 & 1,076 & $9.926,684$ & 17.27 \\
\hline $\begin{array}{c}\text { Kentucky, Missour1, } \\
\text { Tennessee, Texas }\end{array}$ & 5 & 10 & 415 & $2.094,916$ & 3.64 \\
\hline Michigan & 3 & 8 & 508 & $3,338,690$ & 5.81 \\
\hline Minnesota, W1sconsin & 1 & 2 & 100 & 163,210 & 0.28 \\
\hline Ohio & 12 & 35 & 1,878 & $8,619,017$ & 14.99 \\
\hline Pennsylvania & 12 & 46 & 2,962 & $14,679,309$ & 25.54 \\
\hline West Virginia & 2 & 9 & 519 & $3,411,191$ & 5.93 \\
\hline Total & 59 & 199 & 11,413 & $57,483,400^{\mathrm{b}}$ & 100.00 \\
\hline
\end{tabular}

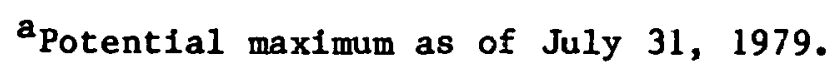

bother estimates are 51.8 million tons in operation, and 47.6 million tons as actual productive capacity.

Source: Ref. 63, as reported in Ref. 6, p. 225. 
Table 6.2 End Uses of Coke Fines Produced in the United States, 1975-1980 ( $10^{3}$ short tons)

\begin{tabular}{lcccc}
\hline & $\begin{array}{c}\text { Use in } \\
\text { Steam } \\
\text { Plants }\end{array}$ & $\begin{array}{c}\text { Use by } \\
\text { Agglomers in } \\
\text { Plants }\end{array}$ & $\begin{array}{c}\text { Other } \\
\text { Industrial } \\
\text { Use }\end{array}$ & Sold \\
\hline 1975 & 257 & 1,202 & 715 & 1,953 \\
1976 & 197 & 1,363 & 838 & 1,846 \\
1977 & 187 & 1,398 & 590 & 1,690 \\
1978 & 167 & 1,550 & 805 & 1,736 \\
1979 & 200 & 1,453 & 745 & 2,240 \\
1980 & 125 & 1,087 & NA & 2,968 \\
& & & & \\
\hline
\end{tabular}

Source: Ref. 28 .

Table 6.3 Coke and Coking Coal Consumption In the United States, 1975-1980

\begin{tabular}{llcl}
\hline Year & $\begin{array}{c}\text { Coke }^{\mathrm{a}} \text { (1b/ } \\
\text { short ton of } \\
\text { pig 1ron) }\end{array}$ & $\begin{array}{c}\text { Coke } \\
\text { Yield } \\
(\%)\end{array}$ & $\begin{array}{l}\text { Coking Coal } \\
(1 \mathrm{~b} / \text { short ton } \\
\text { of pig iron) }\end{array}$ \\
\hline 1975 & $1,221.6$ & 68.4 & 1,786 \\
1976 & 1,187 & 68.9 & $1,722.8$ \\
1977 & $1,192.8$ & 68.9 & $1,731.2$ \\
1978 & $1,4.38 .8$ & 68.6 & $1,667.3^{\mathrm{d}}$ \\
1979 & 1,150 & 68.4 & $1,681.2$ \\
1980 & 1,138 & 69.2 & 1,644 \\
\hline
\end{tabular}

${ }^{a}$ Calculated by dividing coke consumption in: iron furnaces by pig iron production.

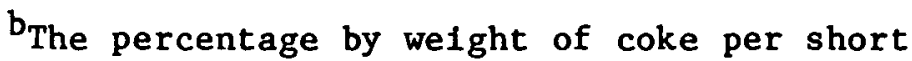
ton of coal carbonlzed.

${ }^{c}$ Calculated by dividing column 1 by column 2 and multiplying by 100 .

$d_{\text {Number }}$ is suspect because it is inconsistent with the 1978 coke rate in Table 6.4 .

Source: Ref. 28 for 1975-1979; Ref. 1 for 1980 . 
Table 6.4 Coal Carbon1zed at Coke Plants, 1975-1979 ( $10^{3}$ short tons)

\begin{tabular}{lcccc}
\hline \multicolumn{4}{c}{ Volat1le Content } \\
\cline { 2 - 4 } Year & High & Medium & Low & Total \\
& & & & \\
\hline 1975 & 57,488 & 9,619 & 15,040 & 82,147 \\
1976 & 56,847 & 9,982 & 16,554 & 83,383 \\
1977 & 51,734 & 9,191 & 15,752 & 76,677 \\
1978 & 47,664 & 9,928 & 13,486 & 71,078 \\
1979 & 49,979 & 9,780 & 17,250 & 77,010 \\
& & & & \\
\hline
\end{tabular}

Aercentage by welght of volatile matter in molsture-free (dry) coal: high is over 31\%; medium 18 22-31\%; and low is $14-22 \%$.

Source: Ref. 28 .

Reduced blast furnace coke rates are possible through the use of supplemental fuels, as Table 6.5 indicates, but with the price of ofl and gas rising, this is an increasingly expensive option. Since 1978, the industry has substituted coke for hydrocarbons as their relative prices have shifted.

\subsection{ENEERGY CONSÉERVATION MEÁSURES FOR COKE OVENS}

Table 6.6 presents several estimates of energy consumption in the manufacture of coke. These estimates are very close, indicating that energy use in the manufacture of coke appears to be well understood. The efficiency of coke ovens has always been quite high; a recent study comparing the efficiencies of 1ronmaking and steelmaking indicates that. U.S. ovens operate at an efficiency of $88 \%-1 . e$. , only $12 \%$ of the heating value of coal 18 lost in the process. 65

Energy conservation measures for the coke ovens are as plentiful and diverse as the opinions held about their cost-effectiveness. Table 6.7 describes nine such options. Of these nine, only coal preheating, formed coke, and dry quenching are discussed.

\subsubsection{Coal Preheating}

Of the various conservation alternatives, coal preheating appears to be the least controversial and most 11 kely to penetrate coke production in the 
Tab1e 6.5 Blast Furnace Output and Coke Consumption, 1964-1980

\begin{tabular}{|c|c|c|c|c|c|}
\hline Year & $\begin{array}{c}\text { Blast Furnace } \\
\text { Production } \\
\left(10^{6} \text { net tons }{ }^{a}\right)\end{array}$ & $\begin{array}{c}\text { Coke } \\
\text { Consumed } \\
\left(10^{6} \text { tons }\right)\end{array}$ & $\begin{array}{c}\text { Supplemental } \\
\text { Fuels } \\
\text { Consumed } \\
\left(10^{6} \text { tons }\right)\end{array}$ & $\begin{array}{l}\text { Coke } \\
\text { Rate }\end{array}$ & $\begin{array}{l}\text { Total Fuel } \\
\text { Rate (net } \\
\text { ton/net ton } \\
\text { of hot metal) }\end{array}$ \\
\hline $\begin{array}{l}1964 \\
1965 \\
1966 \\
1967 \\
1968 \\
1969 \\
1970 \\
1971 \\
1972 \\
1973 \\
1974 \\
1975 \\
1976 \\
1977 \\
1978 \\
1979 \\
1980\end{array}$ & $\begin{array}{r}86.2 \\
88.9 \\
92.2 \\
87.6 \\
89.3 \\
95.5 \\
91.8 \\
81.7 \\
89.4 \\
101.2 \\
95.9 \\
79.9 \\
86.9 \\
81.3 \\
87.7 \\
87.0 \\
68.7\end{array}$ & $\begin{array}{l}57.1 \\
59.1 \\
59.6 \\
56.2 \\
56.2 \\
60.2 \\
58.2 \\
51.5 \\
54.6 \\
60.7 \\
58.8 \\
48.8 \\
51.6 \\
48.5 \\
51.3 \\
50.6 \\
41.5\end{array}$ & $\begin{array}{c}1.743 \\
2.083 \\
2.270 \\
2.201 \\
2.376 \\
2.620 \\
2.778 \\
2.614 \\
3.401 \\
4.056 \\
4.926 \\
3.874 \\
4.232 \\
3.531 \\
4.311 \\
\text { NA } \\
\text { NA }\end{array}$ & $\begin{array}{l}0.663 \\
0.665 \\
0.647 \\
0.642 \\
0.629 \\
0.630 \\
0.634 \\
0.630 \\
0.611 \\
0.600 \\
0.612 \\
0.611 \\
0.594 \\
0.597 \\
0.585 \\
\text { NA } \\
\text { NA }\end{array}$ & $\begin{array}{c}0.683 \\
0.688 \\
0.671 \\
0.667 \\
0.656 \\
0.658 \\
0.664 \\
0.662 \\
0.649 \\
0.640 \\
0.665 \\
0.659 \\
0.643 \\
0.640 \\
0.634 \\
\text { NA } \\
\text { NA }\end{array}$ \\
\hline
\end{tabular}

a Net throughput, excluding Iron output that is recycled.

${ }^{b}$ Coke equivalents.

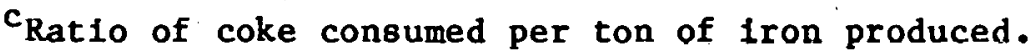

Source: Ref. 62 for 1964-1978; Ref. 32 for 1979-1980.

near term. The first commerclal use of coal preheating was in 1970, and many Installations, Including such large facilities as Jones \& Laughlin's Aliquippa works and Inland Steel's Indiana Harbor facllity, have a long history of operation. 30 Several estimates are available for the amount of energy saved due to reduced cuke oven underfiring, faster coking, and elimination of leveling. Battelle. ${ }^{66}$ estimates savings of $2 \times 10^{6} \mathrm{Btu} / \mathrm{t}$ on of coke, while A.D. Little $\mathrm{8}^{8}$ estimates a $10 \%$ savings over conventional processes, even after allowance is made for the additional steam and electricity consumed to operate the preheater.

The major benefits of coal preheating include not only the direct energy savings achleved in coke manufacture, but also the improved quality of the coke produced, and the consequent reduction in coke charged to the blast furnace; alternatively, poorer-quality coals could be used to produce a coke 
Table 6.6 Enærgy Consumption to Manufacture Coke

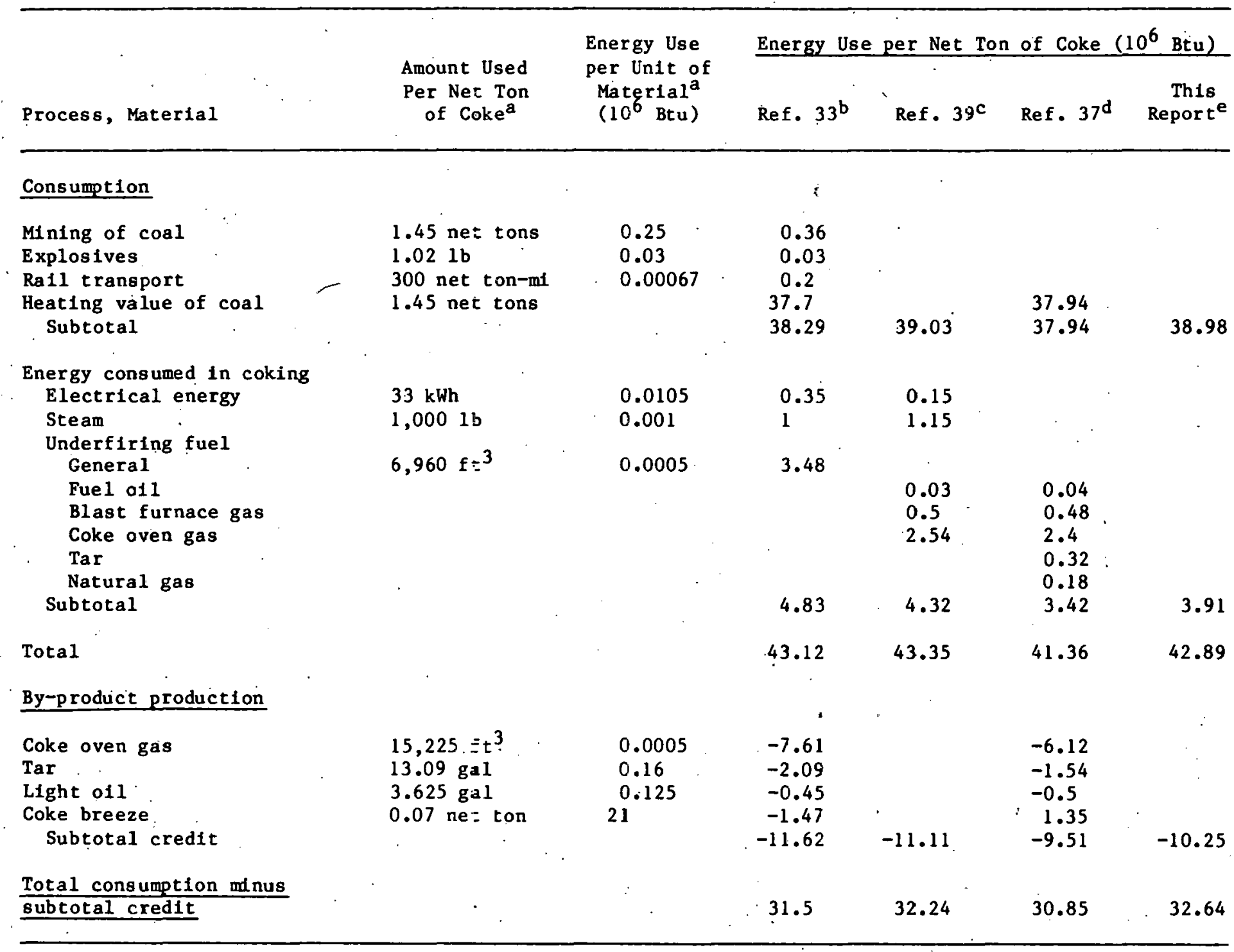

${ }^{a}$ Ref. 33 (1975 data); b1975 data; c1976 data; d1974 data; e 1980 data. 
Table 6.7 Coke Oven Conservation Opt1ons

1. Automatic thermal control of coke batterles instead of manual control is expected to reduce fuel consumption, increase coke yleld, and improve the quality and unfformity of coke pieces.

2. Thermal stabilization of coke aims at increasing the yleld of coke lumps with improved characteristics (size distribution, mechanical strength, carbon activity) for blast furnace use by optimizing coking residence time. Thermal stabilization could result by increasing oven residence time in the case of dry coke quenching.

3. Dry coke quenching enables energy from the incandescent coke to be recovered (as steam), and could also result in: lesser pollution, climination of water use, production of coke without residual moisture, shorter time for stabilization in ovens, and general improvement in coke quality.

4. Charging coke ovens with preheated coking coals is expected to improve the overall energy balance, significantly increase coke oven productivity, Increase uniformity in the mechanical characteristics of the coke (possibly thereby enabling the use of coals with moderate coke properties), and eliminate pollution caused by dust when the ovens are charged. The charge can could be preheated with the heat recovered from dry quenching.

5. Briquetting noncoking coal with coke oven tar as a binder for making coke in coke ovens is an alternative to selling coke oven tar for chemical use, particularly when prices are low.

6. Use of thin wall coke ovens and special refractories will allow a fast, programmed warm-up period and may significantly shorten coking time, enabling indirect energy savings and proportionately lower investment costs.

7. Nontraditional coke forming processes, such as formed coke, can use moreeconomic fossil fuels, diversifying the sources of coal and obtaining greater supply flexibility. The gas distilled off in the first phase of manufacture of formed coke may have new chemical uses or general use as a fuel, or can be injected into the blast furnace.

8. Reduced temperature coking (at $400-600^{\circ} \mathrm{C}$ rather tliall $1000^{\circ} \mathrm{C}$ ), can achieve a semicoke which, though not as strong or as uniformly sized as hightemperature coke, can be used in blast furnaces at a considerable savings in the energy required to produce the coke. ${ }^{a}$ The gas yield is less than that of coke oven gas from temperature-produced coke but has about twice the heating value. Residual volatiles in low-temperature coke will be released in the blast furnace and added to the top gas produced.

9. Partial (surface) coking is duite at the typically high temperature of modern coke ovens, but at a greatly reduced residence time, which indirectly saves energy by increasing coke oven productivity. The semicoke produced has many of the poor qualities of reduced-temperature coke, such as low strength and poor size distribution.a

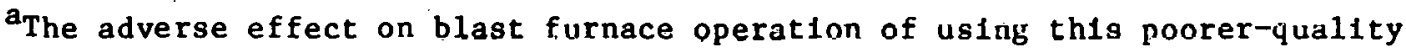
coke may more than offset any energy savings in coke manufacture.

Source: Adapted from Ref. 65. 
equal in quality to that made from high-grade coals. Improved resistance to abrasion, improved stability, improved homogeneity, and decreased proportions of coke less than $40 \mathrm{~mm}$ in size (which increases blast furnace permeability) are cited as the reasons why coke made from preheated coal outperforms coke produced by normal means. ${ }^{7}$ No estimates of the indirect energy savings associated with this increase in quality are available.

\subsubsection{Coke Dry Quenching}

The most controversial conservation measure in the coke-making process, and very likely in the entire iron and steel industry, is dry quenching of coke. The first thought one has when seeing the enormous clouds of steam rising from the wet quenching bin of a conventional coke plant is to save all that energy, and reduce all that pollution. Because "waste" and pollution are so visible in the conventional process, wet quenching has been a favorite target of those in and out of the industry who wish to promote energy conservation and a clean environment.

At least three foreign processès exist for dry yuutililig: the German Sulzer process, dating back to 1917; the Russian Giprokoks process (used in 20 Russian coke batteries producing 16 million tons/yr of coke, and being installed in three Japanese plants); and the Waagner-B1ro process. ${ }^{68}$ In addition, DOE and U.S. Steel are constructing a pilot facility for U.S. Steel's Lorain/Cuyahoga works using a cooling chamber of the company's own design. ${ }^{69}$ The key to the plan is that the batteries can be retrofitted one at a time, holding production disruption to a minimum, if sufficient space at the plant exists.

Energy savings estimates are all in the range of $1.1-1.3 \times 10^{6}$ Btu of the estimated $1.4 \times 10^{6}$ Btu lost through wet quenching. $30,66,70$ What is in dispute is the cost-effectiveness of the process. Two parameters dominate the economics of the operation: (a) the value of the heat saved; and (b) the capital cost of the equipment. AISI, usling costs of $\$ 2.25 / 10^{3}$ lb of $\varepsilon$ taam (generated by coa 1 ) and $\$ 15-20$ million for a 2000-ton/day plant, calculated a payback period of 18.29 years. 70 Increases since then in both steam and capital costs leave that conclusion unchanged. However, the vendor, $\Lambda$ merican Waagner-Biro Co., used stean valued at $\$ 3.75 /$ million BEu (twice tho value assigned by AISI) and a capital cost of $\$ 10 /$ ton (one-half that of AISI), and claimed a 3-5 year payback. 30 Soviet claims of a $2-4 \%$ reduction in the blast furnace coke rate due to increased coke quality (better hardness, stability, uniformity) could, if true, save up to $0.75 \times 10^{6} \mathrm{Btu} / \mathrm{t}$ on of coke, or about $12 \%$ of the $6 \times 10^{6} \mathrm{Btu} /$ ton of coke lost due to process inefficiency. 30 


\subsubsection{Formcoke}

Formcoking, a complete substitute for the conventional slot oven coke process, 1nvolves grinding and preforming the coal, which 18 then binded, pelletized, cured to a char, and completely devolitized to develop the necessary strength, a major problem in coke manufacture. Since briquettes are the final product, their unfform size and shape will improve blast furnace productivity; In addition, the process is enclosed, reducing emission problems. AISI reports two dozen formcoke processes; the early goal was to produce a smokeless coal; recently, the alm has been to produce a metallurglcal-grade coke from cheaper coal blends or a single coal. 70 Two domestic technologies that have recelved major attention are the Food Machinery Corp. (FMC) and Consol-BNR processes, which are briefly described in Table 6.8.

The processes do not necessarily conserve energy although formcoking is a resource-saving technology. 71 Indeed, Thermo Electron estimates that the FMC process, w111 result in integrated mills using an additional $2.5 \times 10^{6}$ Btu/ton of coke, ${ }^{39}$ since the decreased heating value of the by-product gas more than offsets any gains due to improved coal/coke and coke/iron ratios. Further, the demand for tar binder exceeds the amount of by-product tar produced from the process. Finally, there is some question regarding the cokerate savings for the FMC process. The formcoke is of low strength and low stability, and, as such, the blast-furnace coke rate may be increased. There appears to be 11ttle question about the coking properties of the FMC formcoke as a partial replacement, but complete replacement "has not been completely proven in trials to date." 72

Table 6.8 Formcoke Processes in the United States

Consol-BNR Hot pelletizing, coking in a vertical-shaft furnace

FMC
Multiple fluid bed, low-temperature carbonization, briquetting, coking in a verticalshaft furnace
Any type of coal, with coking coal and sometimes pitch as a binder

High-volatile coals of any rank
Metallurgical, sphericalshaped coke

Meta.1.1urgical coke

Source: Adapted from Ref. 70. 
The Conso1-BNR process advocated by Formcoke Associates mixes preheated crushed coal with recycled coke fines, char, and pitch. The blend is hotpelletized, then coked in a shaft furnace. The brief history (1971-1977) of the Sparrow's Point 500-ton/day pilot plant provided evidence that serious technical problems must be solved prior to full-scale production. Unlike the FMC process, the Formcoke Associates project has the certain potential to save energy, since the offgases are of higher quality $\left(850 \mathrm{Btu} / \mathrm{ft}^{3}\right)$ than those from conventional by-product slot ovens.

\subsection{NONRECOVERY COKE MAKING}

Prior to $1910,100 \%$ of the coke needed by the steel industry was provided hy nonrecovery coke processes -- 1.e., those in which the by-products were combusted at the coking site, and not recovered. The advent of coal chemicals as strateglc war materials in the two world wars and the Korean conflict led to the rapid replacement of these processes by vertical slot, byproduct coke ovens that capture the coal chemicals in the by-product tars and light olls, while using the offgas as a heat source. With the decline in value of coal tar-based chemlcal products, due to the reduced costs of the same products from the ofl and gas-based petrochemical industry, a return to a $100 \%$ combustion process for coke manufacture is posstble.

There are now three U.S. nonrecovery coke plants, which account for less than $2 \%$ of coke production. The ovens, according to one oven promotor, cost four to five times less than by-product ovens; they are also nonpolluting and can conserve energy by generating steam. 73 other industry sources say that the ovens actually require $75-100 \%$ of the investment required for byproduct ovens, and hence have little opportunity to become profitable investments in the near future. 
7 THE BLAST FURNACE AND EXTERNAL DESULFURIZATION

\subsection{THE BLAST FURNACE}

\subsubsection{Pig Iron Production Process}

Figure 7.1 shows the components of a typical modern blast furnace. The primary function of a blast furnace is to produce pig iron for introduction into steelmaking furnaces, although a small amount (less than $5 \%$ ) is shipped each year to foundries. The manufacture of pig iron requires an input burden that may consist of agglomerated ores (pellets and/or sinter), lump ores, limestone, and coke. The coke supplies carbon monoxide, which combines with hematite and magnetite to form carbon dioxide and $\mathrm{FeO}$ at the upper end of the furnace at $1200^{\circ} \mathrm{F}$. Flux materials are calcined, and, as the FeO descends to the hotter $\left(3000^{\circ} \mathrm{F}\right)$ portions of the furnace, it combines with carbon or carbon monoxide to produce iron $(\mathrm{Fe})$ and $\mathrm{CO}_{2}$, completing the reaction.

The output of a blast furnace is pig iron, slag (formed by combination of limestone with sulfur and other impurities), and an offgas with a heating value of 75-95 Btu/ft ${ }^{3}$. This heating value has been dropping recently, as a result of lower coke rates and better burden preparation. During the production of pig iron (which is tapped every 3 to 5 hours in quantities of 300-600 tons), a portion of the offgas is consumed in boilers that produce compressed air via steam-powered or electric blowers. Funneling the air through three or four hot blast stoves provides the heat required in the blast, which is blown in at a temperature of $1400^{\circ} \mathrm{F}$ to $2000^{\circ} \mathrm{F}$ (when rebricked) at the tuyeres near the bottom of the blast furnace. (Temperatures of $2400^{\circ} \mathrm{F}$ are common in Japan.) After tapping, the pig iron is transported to the steelmaking furnaces in liquid form via torpedo cars or ladles. The blast furnace is somewhat versatile and can accept a variety of metal charges (mixes of scrap, sinter, pellets, lump ore) with little change in performance for a given Fe content, although large furnaces are less flexible.

U.S. blast furnace capacity has been slowly dropping as steel output and integrated mill shares decline, and as the older furnaces drop out of production. One source estimated that, in 1972, blast furnace capacity was 119 million tons, 72 million tons of which was in plants built prior to 1945. 57 Capacity utilization dropped from a high of $97.5 \%$ in 1973 to just under $50 \%$ in recent years. Two new blast furnace installations, Inland's 10,000 ton/day and Stelco's 5,250 ton/day Canadian plant, were added in 1980, the first significant additions since the Sparrow's Point furnace went on-1ine in November 1978. The total number of blast furnaces dropped to 152 in 1980 , down from 178 in 1978. 74 Hot metal production has not declined as much, since the throughput efficiency (measured in tons/day per $100 \mathrm{ft}^{3}$ of furnace) for the remaining blast furnaces in operation has continued to increase due to better operating practices. 


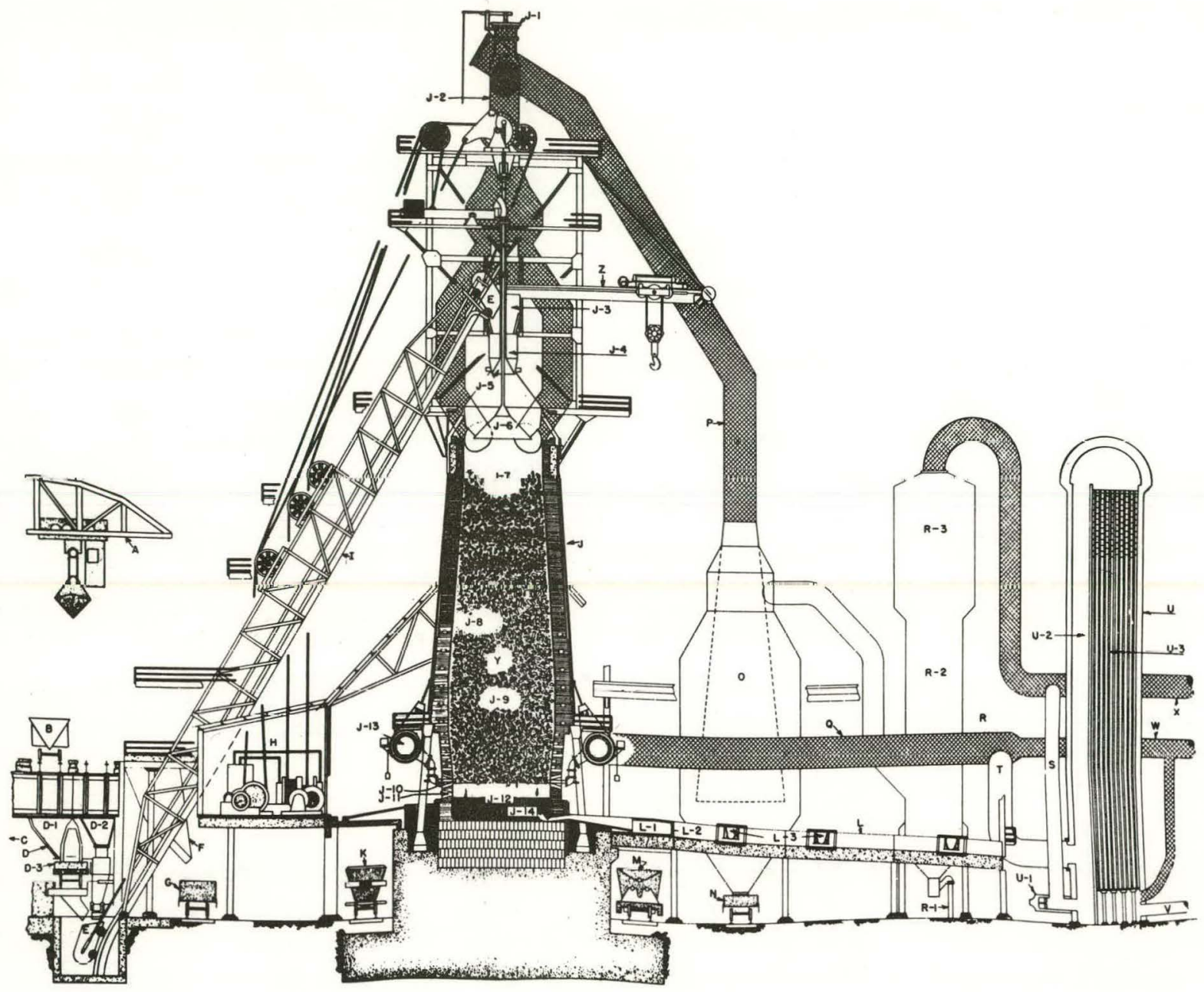
A. Ore bridge
B. Ore transfer car
C. Ore storage yard
D. Stockhouse
D-1 Ore and limestone bins
D-2 Coke bin
D-3 Scale car
E. Skip
F. Coke dust recovery chute
G. Freight car
H. Skip and bell hoist
I. Skip bridge
J. Blast furnace
J-1 Bleeder valve
J-2 Gas uptake
J-3 Receiving hopper
J-4 Distributor

\author{
Legend \\ J-5 Small bell \\ J-6 Large bell \\ J-7 Stock line \\ J-8 Stack \\ J-9 Bosh \\ J-10 Tuyeres \\ J-11 Slag notch \\ J-12 Hearth \\ J-13 Bustle pipe \\ J-14 Iron notch \\ K. Slag ladle \\ L. Cast house \\ L-1 Iron trough \\ L-2 Slag skimme \\ L-3 Iron runner \\ M. Hot-metal ladle \\ N. Flue dust car \\ O. Dust catcher \\ P. Downcomer \\ Q. Hot blast line to furnace \\ R. Gas washer \\ R-1 Sludge line to thickener \\ R-2 Spray washer \\ R-3 Electrical precipitator \\ S. Gas offtake to stove burner \\ T. Hot blast connection from stove \\ U. Stove \\ U-1 Gas burner \\ U-2 Combustion chamber \\ U-3 Checker chamber \\ V. Exhaust gas line to stack \\ W. Cold blast line from blower \\ X. Surplus gas line \\ Y. Stock-Iron ore, coke, limestone \\ Z. Jib boom crane \\ (ㄷ) COPYRIGHT $1971 \mathrm{BY}$ \\ UNITED STATES STEEL CORPORATION
}

Fig. 7.1 Typical Modern Blast Furnace

(Source: Ref. 75) 
7.1.2 Energy and Materials. Use

As the largest consumer of energy and materials in the 1ron and steelmaking process, the blast furnace has recelved much attention. The primary alms in the past were to reduce the per ton use of coke or to increase productivity, rather than to decrease total energy use. Now, more attention is being paid to the latter.

Figure 7.2. shows how varlous factors influence blast furnace productivity. Materials flows and direct and indirect energy consumption per ton of hot metal produced are shown in Table 7.1. Direct energy use estimates are in the range of 15-18 $\times 10^{6}$ Btu/ton, depending on a host of factors. Unit materials flows are shown in Table 7.2.

\subsubsection{Methods of Reducing Coke Use}

Varinịts methods have been used to reduce coke use:

- Installing new blast furnaces with high top pressures;

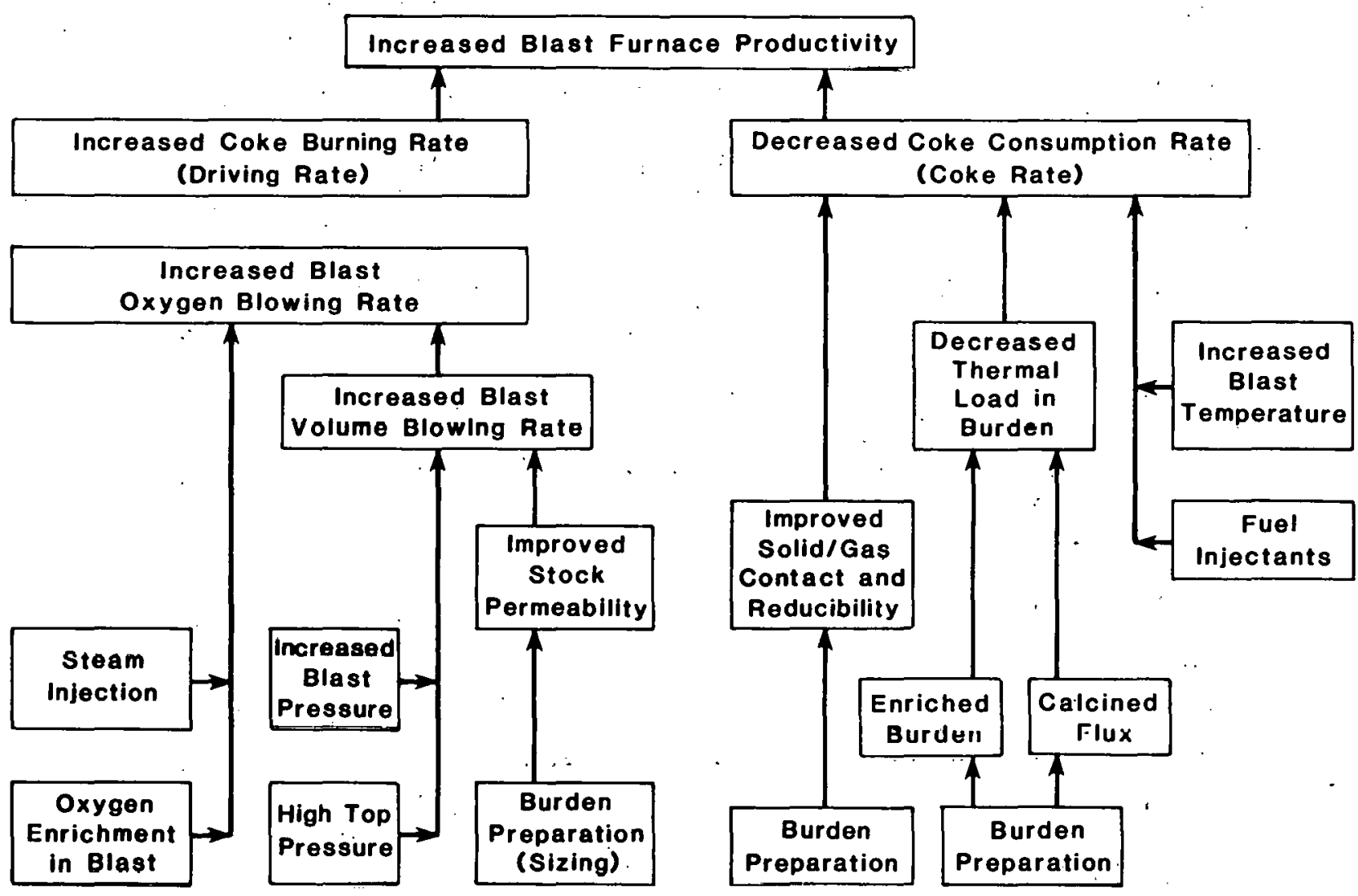

Fig. 7.2 Factors Governing Blast Furnace Productivity

(Source: Ref. 79) 
Table 7.1 Direct and Indirect Energy Consumption In a Blast Furnace, 1980

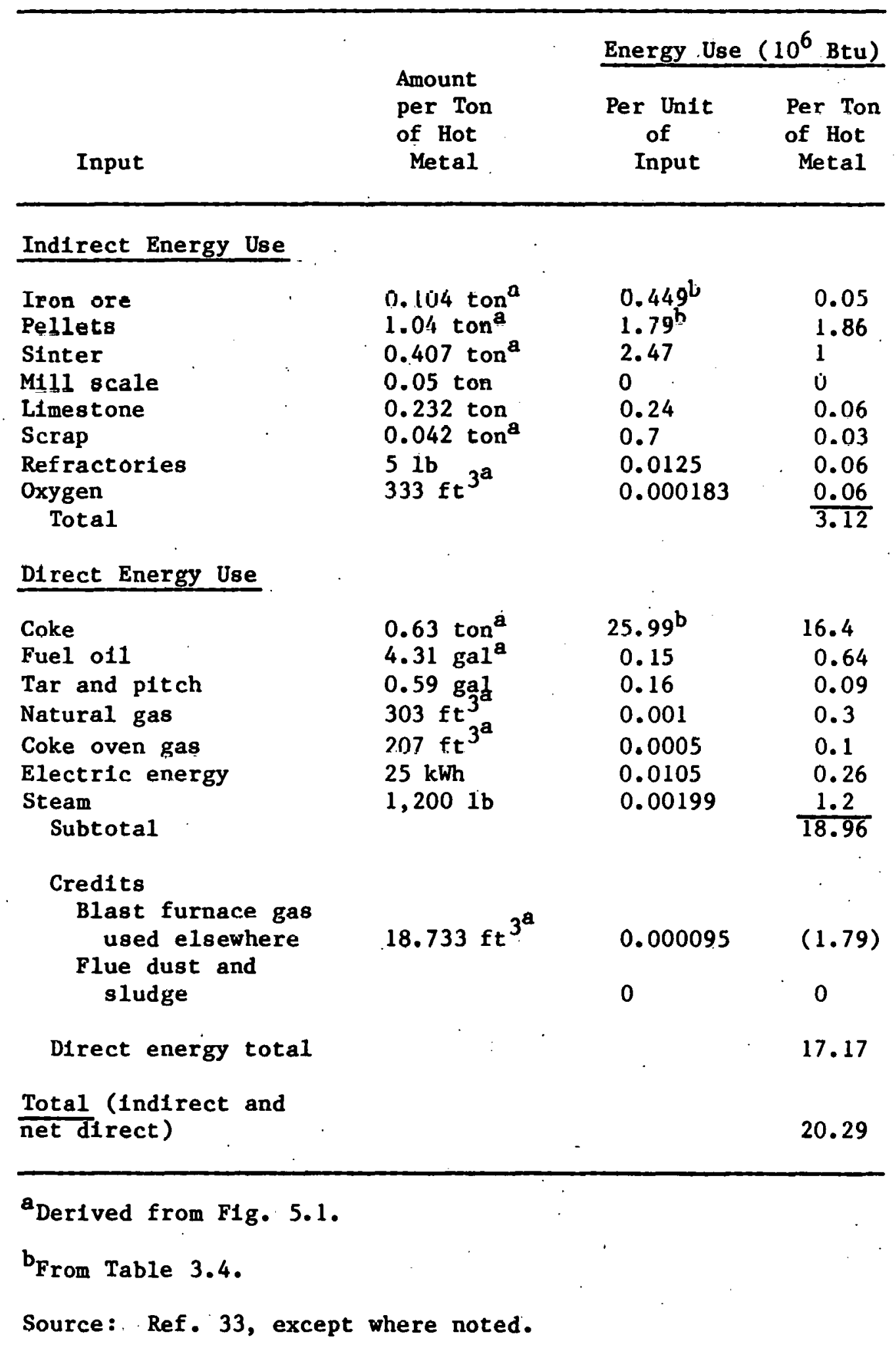


Table 7.2 Materials Used in. Blast Furnaces, 1973-80

(tons/ton of hot 1ron, except where indicated)

\begin{tabular}{|c|c|c|c|c|c|c|c|}
\hline Materlal & 1980. & 1979 & 1978 & 1976 & 1975 & 1974 & 1973 \\
\hline Input & & . & & & & & \\
\hline \multicolumn{8}{|l|}{ Ore } \\
\hline $\begin{array}{l}\text { Iron ore (including } \\
\text { manganiferous and } \\
\text { block) }\end{array}$ & 0.104 & 0.11 & 0.164 & 0.203 & 0.296 & 0.429 & 0.408 \\
\hline $\begin{array}{l}\text { Manganese ore } \\
\text { (including ferru- } \\
\text { ginous manganese) }\end{array}$ & 0.003 & 0.004 & 0.004 & 0.001 & 0.002 & 0.002 & 0.002 \\
\hline $\begin{array}{l}\text { Agglomerated } \\
\text { products (sinter, } \\
\text { pellets, etr.) }\end{array}$ & 1.459 & 1.455 & 1.394 & 1.373 & 1.310 & 1.222 & 1.222 \\
\hline Total & 1.566 & 1.569 & 1.562 & 1.577 & 1.608 & 1.651 & 1.632 \\
\hline $\begin{array}{l}\text { Less flue dust } \\
\text { and sludge } \\
\text { produced }\end{array}$ & $(0.026)$ & $(0.029)$ & $(0.03)$ & $(0.028)$ & 0.031 & 0.033 & 0.031 \\
\hline Net total & 1.54 & 1.54 & 1.532 & 1.549 & 1.577 & 1.618 & 1.601 \\
\hline $\begin{array}{l}\text { Scrap } \\
\quad \text { Total }\end{array}$ & 0.058 & 0.052 & 0.05 & 0.045 & 0.051 & 0.048 & 0.043 \\
\hline $\begin{array}{l}\text { Less production at } \\
\text { blast furnaces and } \\
\text { auxiliary units }\end{array}$ & $(0.016)$ & $(0.017)$ & $(0.016)$ & $(0.017)$ & $(0.017)$ & $(0.017)$ & $(0.016)$ \\
\hline Net total & 0.042 & 0.035 & 0.034 & 0.028 & 0.034 & 0.031 & 0.027 \\
\hline $\begin{array}{l}\text { Mill cinder, roll } \\
\text { scale, etc. }\end{array}$ & $n .044$ & 0.054 & 0.052 & 0.049 & 0.044 & 0.048 & .0 .05 \\
\hline $\begin{array}{l}\text { Limestone, dolomite, } \\
\text { and other flux } \\
\text { materials }\end{array}$ & 0.182 & 0.198 & 0.197 & 0.213 & 0.234 & 0.244 & 0.232 \\
\hline $\begin{array}{l}\text { Coke } \\
\text { Total }\end{array}$ & 0.588 & 0.596 & 0.607 & 0.615 & 0.632 & 0.632 & 0.617 \\
\hline $\begin{array}{l}\text { Less coke breeze } \\
\text { recovered }\end{array}$ & $(0.018)$ & $(0.021)$ & $(0.022)$ & $(0.021)$ & $(0.021)$ & $(0.023)$ & $(0.02)$ \\
\hline Net total & 0.57 & 0.575 & 0.585 & 0.594 & 0.611 & 0.609 & 0.597 \\
\hline Output $\left(10^{6}\right.$ tons $)$ & 68.721 & 87.003 & 87.679 & 81.328 & 86.870 & 79.923 & 95.909 \\
\hline
\end{tabular}

Source: Ref. 59, Tables 39 and 44. 
- Improving old blast.furnaces by retrofitting;

- Increasing a1r-blast temperatures;

- Optimizing burdens;

- Using prereduced burdens; and

- Injecting hydrocarbons.

Most of the blast furnaces operating today were Installed before 1950 and less than five operate above $10 \mathrm{psig}$. Coke usage can be reduced by increasing the top pressure, since higher pressures intensify the physical and chemical 1nteractions. Thermo Electron reports that, at the optimal wind rate, savings amount to $100 \mathrm{lb}$ of coke per ton of pig 1ron, 39 while Woolf indicates that larger savings are possible, as well as dramatic increases in blast furnace productivity. $\%$ The AISI Blast Furnace Committee estimates much lower savings; a 1-psig increase reduces the coke rate by only one pound according to its formula. 77 New blast furnaces can be designed for higher top pressures: In Japan, top pressures are as high as 32 psig. At these pressures, substituting expansion turbines for Septum valves allows $20-40 \%$ of the energy expended on blowing power to be recaptured. 78 With capital costs at $600-700 / \mathrm{kW}$, AISI predicts a value of return on investment of $14-18 \% .70$

Relining and rebricking in existing blast furnaces and stoves allow for Increased alr-blast temperatures; between 1958 and 1968, the average Increased from $1230^{\circ} \mathrm{F}$ to $1500^{\circ} \mathrm{F}$. Each $100^{\circ} \mathrm{F}$ increase in blast temperature above $1800^{\circ}$ decreases the coke charge by about $30 \mathrm{1b} / \mathrm{ton}$, and temperatures around $2200^{\circ} \mathrm{F}$, which would save $102 \mathrm{lb} / \mathrm{ton}$, are considered obtalnable with relining at a cost of $\$ 5 /$ ton of yearly capacity.39 However, reducing coke rates increases the need for hydrocarbon purchases, since offgas quality declines.

Optimization of burden 18 most easily achleved by use of bell-less tops, whlch offer three distinct advantages: (a) coke usage can be reduced by $30 \mathrm{lb}$ per ton of pig 1ron; (b) capital costs may be lower, depending on the site; and (c) the burden input $\mathrm{mix}$ can be distributed more uniformly, allowing better gas efficiency.

The possibility of substituting prereduced burdens for ore has recelved some attention. U.S. Steel has established that, as a direct result of the metallic ore ( $\mathrm{Fe}$ ) contalned in the directly. reduced material, for each $100 \mathrm{lb}$ of that material charged per ton of hot metal produced, the production rate Increases by $4 \%$ and the coke rate drops by $321 \mathrm{~b} .77$ However, the U.S. Steel report concludes that " $95 \%$ directly reduced iron can only be used economically in the blast furnace if its purchased cost is below its breakeven value." 80 This calculation is based on 1981 prices and a coal-based process; perhaps future differential fuel prices will change this, since the conclusion is malnly dependent on the cost of coke and the cost of iron oxide. 
Injection of hydrocarbons. Involves mainly natural gas injected through "circle pipes". and oll and coal injected through lances. Since 1979, hydrocarbon fuel injection has been markedly reduced because of the economics. The total energy 1mpact has been estimated at various amounts. Both the Bureau of Mines and Battelle have observed that total energy input increases when gas and ofl are injected. Th1s, coupled with the slight energy loss at the coke plant assoclated with reductions in throughput, means a decrease in thermal efficiency as hydrocarbons are substituted for coke. 39 However, as supplies of natural gas dwindle, more steelmaking concerns are attempting to utilize pulverized coal as the main injectant into the blast furnace, which does conserve energy - about $0.7 \times 10^{6} \mathrm{Btu} / \mathrm{t}$ on of hot metal, 66 although this has been disputed by AISI, which concludes that "the energy input to the blast furnace will normally increase." 71 Payback periods are in the 3-4 yr range, so commercialization is 1ikely. Armco's system (the only system now in use in the United States) substitutes coal at a rate of $0.781 \mathrm{~b}$ of coke per pound of coal up to $28 \%$ of the coke input. 81 Retrofit capital costs for the coal-pulverizing equipment are $\$ 6.50 /$ ton of yearly capacity. 71

Thus, some ways of lessening the per ton use of coke do not necessarily lower the energy consumption per ton of pig iron produced. Tenenbaum has described the dilemma of the steel producers trying, on the one hand, to meet federal energy conservation targets for total energy use, while on the other hand trying to follow government mandates to switch to coal.82 Inland's experience is to replace coal with ofl and gas in order to save energy in the blast furnace, but this solution substitutes domestically scarce energy sources - o 11 and gas -- with a readily avallable source, coal. Which policy should be followed? Tenenbaum points out that if cost minimization dictates the choice, hydrocarbon injection is preferable to increasing coal input (at 1977 prices).

\subsubsection{Methods of Increasing Blast Furnace Efficiency}

As discussed above, the rising cost of low-sulfur bituminous coking coals has led to efforts to reduce coke consumption, even at the expense of total energy use -- 1.e., minimizing costs can lead to increased energy use. There are also ways of increasing the efficiency of the blast furnace, although none are dramatic, since the furnaces are very efficient to start with - over 75\%.39 One method 18 to Increase conservation and use of blast furnace offgas, which, while low in quality (75-95 Btu/ft ${ }^{3}$ ), is produced in large quantities; if completely utilized, it would represent about one-fourth of the total energy needed to make steel. 66 At present, most gas is recycled, but about $30 \%$ is lost due to leaks or flaring during perlods of excess supply. Reasonable efforts to capture and recycle could recover an added $0.7 \times 10^{6}$ $\mathrm{Btu} / \mathrm{ton}$, or about $1 \%$ of the energy needed to produce steel slabs. 66 Industry sources say the $30 \%$ waste estimate is too high: a better estimate would be nearer $15 \%$. 
A second Idea, put forward by Woolf, is injection of hot reducing gases into the lower stack to prereduce the iron burden, thus achieving the same effect as charging direct reduction pellets to the furnace. ${ }^{76} \mathrm{H} / \mathrm{s}$ experiments indicate that such injection would substantially reduce the coking rate. For top gas injections in the range of $16,000-17,000 \mathrm{ft}^{3} / \mathrm{THM}$, coke rates were reduced by $38-41 \mathrm{lb} / \mathrm{THM}$, and blast furnace offgases increased from $89 \mathrm{Btu} / \mathrm{ft}^{3}$ to $122-124 \mathrm{Btu} / \mathrm{ft}^{3}$.

A third Idea 18 to Increase the charging temperatures of raw materials to the furnace by capturing the latent heat of the coke (at $1000^{\circ} \mathrm{F}$ ) and sinter (at $1000^{\circ} \mathrm{F}$ ), and preheating the ore to $500^{\circ} \mathrm{F}$ with process offgases. Hall has estimated that such a practice could save $6 \%$ of the coke charge, or about 1.01 $x \cdot 10^{6}$ Btu per ton of iron. 83 Industry sources say this practice will not be adopted in the near future, since the capital costs of handling such very hot materials would be considerable.

Another approach 18 to use blast furnace gas, in excess supply in many plants, to preheat stove alr - a practice planned for Stelco's blast furnace, but temporarily shelved until the economics improve. 84

Slag production at the blast furnace 1s about $1,100 \mathrm{lb}$ per ton of iron and absorbs about $1.7 \times 10^{6} \mathrm{Btu}$ per ton, or $9 \%$ of the heat of the furnace. If this heat could be reclaimed and used to produce steam and then electriclty, it could generate $10 \%$ of the electricity purchased by the industry in a year. 85 Problems are associated with the 1dea. In particular, slag tapping is Infrequent; how could the heat be recovered prior to slag hardening? Further, industry sources say the $1,100 \mathrm{lb} /$ ton figure, and hence the potential energy savings, is overstated by a factor of nearly two.

\subsection{EXTERNAL DESULFURIZATION}

Sulfur is an unwanted contaminant in steel, affecting only surface quality in some instances, but in other cases, such asin steel for magnets, adversely affecting performance. Several alternatives exist to decrease the sulfur content in steel:

- Use low-sulfur coals in coke plants and low-sulfur oils in blast furnaces;

- Remove sulfur in the blast furnace by control of basic slag analys 1s;

- Apply soda ash In the hot ladle; or

- Remove sulfur in the steelmaking facilities.

Several trends have combined to place the main burden of increased sulfur removal on the blast furnace: the rising cost of low-sulfur coal and 
o11, which has led to increased sulfur levels in metallurgical coal, the growing use of BOF steelmaking facilities with limited possibilities for sulfur removal, and the increasing demand for low-sulfur, low-alloy steels to make pipelines and sheet. The result has been to necessitate greater use of burned lime as a fluxing and desulfuring agent, with subsequent increases in the energy load on the furnace. 66

External desulfurization -- the removal of sulfur from hot metal as it is transported from the blast furnace to the steelmaking facility -- is beginning to replace blast furnace methods for removing sulfur, with consequent energy savings. Many technologies exist; the injected reagents include soda ash, calcium carbide, magnesium coke; and magnesium dolomite. 70 When external desulfurization is used to reduce the coke rate in blast furnaces by allowing high-sulfur hot metal to be produced, it saves energy. The amount depends principally on the change in the hot metal sulfur content, and can range from $0.82 \times 10^{6}$ Btu/ton to $-0.12 \times 10^{6} \mathrm{Btu} / \mathrm{ton} .70$ Battelle estimates that the possible energy savings can amount to $0.9 \times 10^{6} \mathrm{Btu} / \mathrm{ton},{ }^{66}$ while A.D. Little estimates $0.86 \times 10^{6}$ Btu/ton. 30 However, Emerson indicates that, at his site, even if energy prices doubled their 1978 levels, it would still be cheaper to remove sulfur. In the blast furnace when $0.71 \%$ sulfur coke is used. 79

The economics of sulfur removal currently. favor external desulfurization, and many steel companies are installing units. In 1979 and 1980 alone, U.S. Stee1, Inland, Algoma, Dofasco, Stelco, Je1, Republ1c, CF\&I, Nat1onal, Crucible, and Ford all installed efther hot metal or steel external desulfurization facilities. 86 


\section{DIRECT REDUCTION}

Direct reduction (DR) processes (any reduction processes in which metallic iron is produced without melting the material) are basically of two types: gaseous and solid. The first uses a gas, elther hydrogen and/or carbon monoxide, for removing oxygen from iron; the second uses solid carbon. The reactions reduce hematite to magnetite and wustite, and then to $\mathrm{Fe}$. Reductants in use are carbon, hydrogen, and carbon monoxide. An 1deal lump iron ore for use in a DR process would have an iron content of at least $65 \% .77$ Substantial amounts of this type of ore exist abroad, and if a run-of-the-mine ore cannot be used, beneficlated pellet ores can. The product, directly reduced 1ron (DRI), is 90-95\% metallized, and hence is oultable for feed to steelmaking units (electric arcs, BOFs after melting) or ironmaking units (blast furnaces, cupolas).

DK is not a new technology; early man used a primitive version of it around 3000 B.C. to reduce iron minerals to metal. Table 8.1 summarizes data on all DR plants constructed or scheduled for completion by 1980; these plants Include the first Persian Gulf integrated mill in Qatar, which utilizes gas. Many processes are avallable; Table 8.2, taken from a U.S. Steel report (which is the definitive work in the field), Iists 20 separate processes representing five different technologies. However, $75 \%$ of installed capacity is either the Midrex or HyL process, both of which use natural gas as a reductant; coalbased reductant capacity amounts to $11.1 \%$ of the total.

Since coal-based plants are expected to be more economical in the United States as gas prices rise relative to coal, Table 8.3 lists all operating DR plants using coal, coke breeze, or coal gas as a reductant. Table 8.4 gives energy consumption estimates for both the gas and coal reductant processes; coal-based systems use about twice the energy per ton used by gas-based systems.

Major advantages of the pelletization process are:

- The pellets have a known and untform chemical composition, which contains no tramp elements ( $\mathrm{Zn}, \mathrm{Pb}$, etc.) as does the substitute for pellets in mini-mi11s, scrap.

- The pellets can be manufactured easily at a variety of locations, since small-scale plants are as efficient as larger ones, and many reductants can be used (coke, coal, gas, oll, $\mathrm{CO}$, and even $\mathrm{CO}$. and $\mathrm{H}_{2}$ produced from biomass ${ }^{88}$ ).

- The pollution and coal supply problems associated with coke production are. eliminated when pellets substitute for hot metal in integrated mills. 
Table 8.1 Direct Reduction Plants Constructed or Scheduled

for Completion by 1980

\begin{tabular}{|c|c|c|c|c|c|c|c|}
\hline Process & $\begin{array}{l}\text { Number } \\
\text { of } \\
\text { Plants }\end{array}$ & $\begin{array}{l}\text { Year of } \\
\text { First } \\
\text { Plant }\end{array}$ & $\begin{array}{l}\text { Year of } \\
\text { Last } \\
\text { Plant }\end{array}$ & Countries & Reductant & $\begin{array}{c}\text { Annual } \\
\text { Capac1ty } \\
\left(10^{3} \text { tons }\right)\end{array}$ & Type \\
\hline Hozanas & 3 & 1954 & 1954 & Sweden : & Coke breeze & $63-154$ & - \\
\hline Wiberg & 4 & 1954 & 1964 & Sweden, Japan & Coke breeze & $9-82$ & - \\
\hline Rotary kiln & 1 & 1957 & 1957 & Japan & Coal & 22 & RK \\
\hline HyL & 14 & 1957 & 1980 & Mexico ${ }^{b}$ & Natural gas & $91-1905$ & SB \\
\hline Highveld kiln & 2 & 1968 & 1977 & S. Africa & Coal & $272-907$ & RK \\
\hline Midrex & 17 & 1969 & 1980 & Untted States $b$ & Natural gas & $272-2268$ & SF \\
\hline Kawasak1 & 3 & 1969 & 1977 & Japan & Coke breeze & $65-227$ & $\mathbf{R K}$ \\
\hline SL-RN & 6 & 1970 & 1978 & New Zealand ${ }^{b}$ & Coal & $54-327$ & RK \\
\hline Purofer & -4 & 1970 & 1980 & W. Germany ${ }^{6}$ & Natural gas, co & $136-726$ & SF \\
\hline Kono & 1 & 1971 & 1971 & Japan & Coke breeze & 44 & - \\
\hline Armco & 1 & 1972 & 1972 & United States & Natural gas & 300 & SF \\
\hline $\mathrm{Kr}:\lrcorner p p$ & 1 & 1973 & 1973 & S. Africa & Coa1 & 136 & RK \\
\hline HIB & 1 & 1973 & 1973 & Venezuela & Natural gas & 590 & FB \\
\hline Suni tomo & 1 & 1975 & 1975 & Japan & Coal & 218 & - \\
\hline Kubota & 1 & 1975 & 1975 & Japan & Coal & 190 & - \\
\hline ACCAR & 2 & 1975 & 1976 & Canada & Coal, o1l, gas & $45-218$ & RK \\
\hline FIOR & 1 & 1976 & 1976 & Venezuela & Natural gas & 363 & FB \\
\hline NSC & 2 & 1976 & 1977 & Japan & 011 & $136-218$ & - : \\
\hline KInglor-Metor & 1 & 1976 & 1976 & Italy & Coal & 36 & - \\
\hline Azcon $\mathrm{C}$ & $i$ & 1978 & 1978 & United States & Coa1 & 91 & RK \\
\hline
\end{tabular}

$a_{R K}=$ rotary $k i l n, S F=$ static bed, $S F=$ shaft furnace, $F B=$ fluidized bed.

brincipal country; some of the plants are scattered in other countries as well.

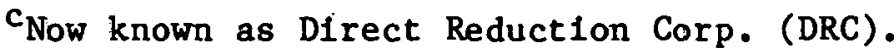

Source: Ref.: 6 . 
Table 8.2 Direct Reduction Processes

First Generation Coal-Based Processes

Krupp-Codir: rotary kiln

$\mathrm{SL} / \mathrm{RN}$ : rotary $\mathrm{kIln}$

DRC: rotary $k 11 n$

Second Generation Coal-Based

Processes

ACLAK: rotary $\mathrm{kiln}$

Hot gas desulfurization (HGD)

shaft reduction

Improved EL/RN: rutaíy kLlu

Salem Reduction: rotary kiln

Coke Oven Gas/DRI from HyL and Midrex
Reformed Natural Gas Processes

Midrex: shaft furnace

HyL: static bed

Purofer: shaft furnace

Armco: shaft furnace

FIOR: fluid bed

New Technology

SKF: plasmame1t

ELRED

INRED

Midrex Electrothermal: shaft furnace

Foster-Wheeler: plasmamelt

Westinghouse

DLM-modified

Source: Adapted from Ref.. 77.

- For plants below one million tons/yr in capacity, the process, coupled with electric melting, has both investment cost and operating cost advantages over the coke oven/ blast furnace/BOF complex. 6

- The productivity of electric arc furnaces can be increased substantially when the pellets are continuously charged. 89

Major disadvantages of the process are:

- It will likely use more direct energy, since the energy intensities in Table 8.4 are generally more than those reported for direct energy use in the blast furnace. Since the DR process and blast furnace both use pellets as an Iron source, the relative advantage of the blast furnace would likely be maintalned if direct and indirect energy use were compared.

- The pellets tend to reoxidize during. shipment, with consequent spontaneous ignition if reduction temperatures are below $900^{\circ} \mathrm{C} .90$ 
Table 8.3 Operating Direct Reduction Plants Based on Coal or Coke Breeze

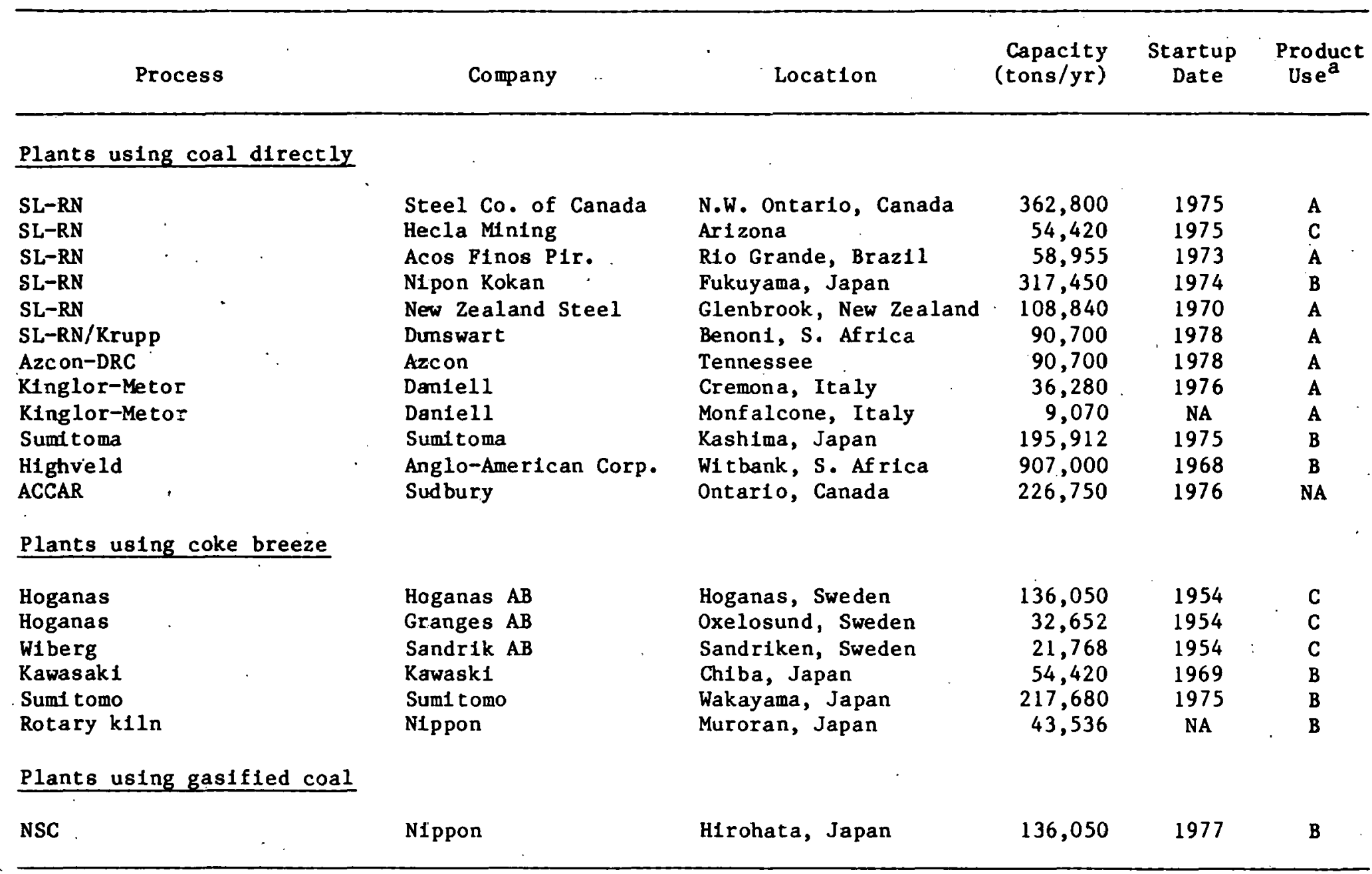

$a_{A}=$ steelmaking feed; $B=1$ ronmaking feed; $C=$ specialty product.

$\mathrm{NA}=$ not available.

Source: $\operatorname{Ref}, 77$. 
Table 8.4 Energy Comparison of Direct Reduction Processes

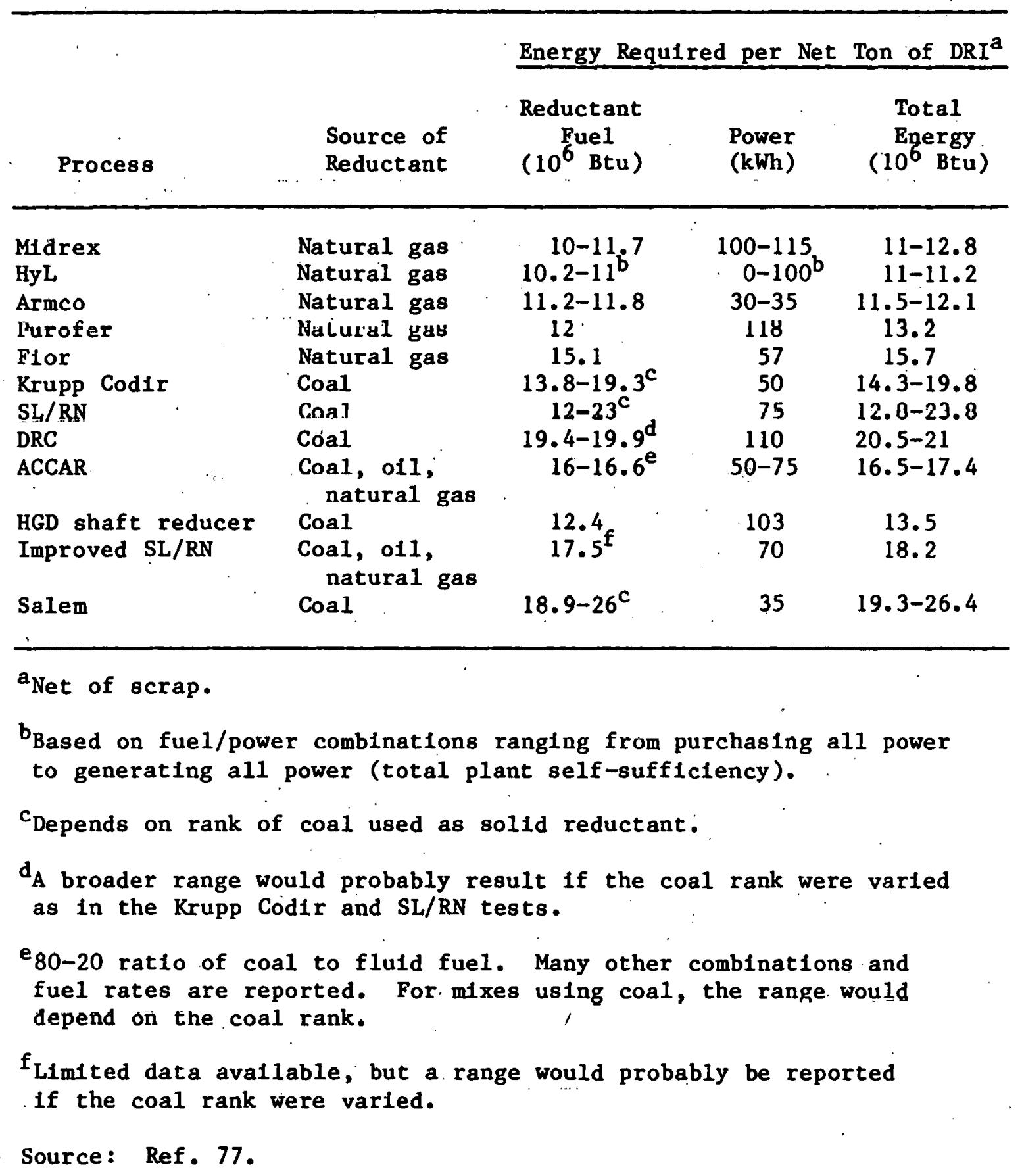


- The more-efficlent processes use natural gas, an expensive fuel. Oregon Steel shut down 1 ts Midrex plant when gas reached $\$ 3.85 / 10^{6}$ Btu. 87

- The pellets must be melted to substitute for hot metal in integrated mills, which adds to the energy disadvantage. Also, use in integrated mills will involve different charging and solld waste handling techniques, since acid slag is produced, requiring subsequent flux addition and slag removal. 89

OTA estimates that DR plants w111 make major inroads into international steel markets in the next 20 years, with North American capacity growing from 2.9 million tons in 1980 to 15.3 million tons by the year $2000 .^{6}$ Hogan predicts short-run potential demand to be in the 6-8 million ton range. 87 Such forecasts are based on future trajectories of gas, coal, and scrap prices that, while reasonable, are subject to uncertainty. In contrast, the U.S. Steel report compares the cost of alternate steelmaking processes by calculatIng the selling price per ton of liquid steel necessary to obtain a $15 \%$ rate of return on investment, using 1981 prices of scrap, pellets, coal, fuel, and electricity. 77 It concludes that two Swedish basic oxygen processes -- SKF Plasmamelt and Inred, with fu11 costs of $\$ 199 /$ ton and $\$ 205 /$ ton of raw steel, respectively -- are already competitive with present coke oven/blast furnace/ BOF practice (whose full cost is $\$ 206 /$ ton of raw steel). The SKF Plasmamelt is also competitive with future blast furnace practice, $1 . e .$, coal injection plus $0_{2}$ blast (with a full cost of $\$ 195 /$ ton of raw steel).

Leary has described the consequences of a major shift to DR in blast furnace charges.91 If DR pellets are substituted for hematite/magnetite pellets in blast furnaces, the coke rate would be cut $50 \%$, causing shortages of coke by-products, while natural gas requirements would increase $2000 \%$. There would be a net energy increase of $0.5 \times 10^{6} \mathrm{Btu} / \mathrm{ton}$ of 1 ron. If $\mathrm{DR}$ pellcto are used as $40 \%$ of the electric arc charge (the rest being scrap) and if the historical $75 / 25$ ratio is maintained between primary (iron ores) and secondary (scrap) Inputs, then Leary predicts much excess blast furnace and BOF capacity, corresponding undercapacity in the electric arcs, excess capacity for blast furnace grade pellets, and a tenfold increase in the demand for electric-arc grade metallized pellets. 91

At present, DRI or sponge Iron is not competitive with scrap la winimills because of reduced scrap consumption and low scrap prices in the depressed steel industry. In the future, with the return of a healthy steel Industry and further use of electric furnaces in both the integrated and nonintegrated portions of the industry, scrap supply w1ll become stralned; DK pellets may then find ready markets in the mint-mill segment, if scrap prices rise sufficiently to make the deepwater port to mini-mill movement of $D R$ pellets profitable. Jensen says that DRI "1s the only thing that will help alleviate an International critical shortage of scrap.".92 


\section{SCRAP}

Besides scrap, mill scale generated from water pollution control equipment in the reduction and rolling mllls and casting areas can contaln over $50 \%$ iron, and is a candidate for recycling. 15 so are some of the dusts and sludge generated throughout the industry. Since this scrap source has been discussed in Sec. 5 on sinter, this section focuses only on revert, prompt, and obsolete scrap. Table 9.1 gives the time pattern of scrap consumption by major type.

\subsection{ENERGY USE IN THE SCRAP INDUSTRY}

Steel. produced from prowpt and obsolete scrap uses $6-8.3 \times 10^{6}$ Btu of energy per ton of raw steel. 31,93 In contrast, steel produced from 1ron ore uses $16-24 \times 10^{6} \mathrm{Btu} / \mathrm{t}$ on (see Sec. 10 and Ref. 94). If the calculation 1.s made on the basio of ateel shlpments, the difference becomes larger $-10 \mathrm{x}$ $10^{6}$ Btu versus $36 \times 10^{6}$ Btu. 6 The difference 18 mainly due to the very large amount of energy used in the blast furnace to produce hot metal ( $12 \times 10^{6}$ Btu/ton ${ }^{24}$ ) versus the smaller amounts used to collect and ship obsolete scrap $-0.55-1.5 \times 10^{6} \mathrm{Btu} / \mathrm{ton} .31,36$

Table 9.1 Consumption of Recoverable Materials in the Iron and Steel. Industry, 1973-1980 ( $10^{6}$ short tons)

\begin{tabular}{|c|c|c|c|c|c|c|c|c|}
\hline $\begin{array}{c}\text { Recoverable } \\
\text { Material }\end{array}$ & 1973 & 1974 & 1975 & 1976 & 1977 & 1978 & 1979 & 1980 \\
\hline Scrap & & & & . & & & & \\
\hline $\begin{array}{l}\text { Home scrap } \\
\text { production } \\
\text { Purchased }\end{array}$ & 50.41 & 47.42 & 40.06 & 43.46 & 47.42 & 44.9 & 45.3 & 36.8 \\
\hline $\begin{array}{c}\text { scrap } \\
\text { recelved } \\
\text { Total }\end{array}$ & 32.06 & 33.65 & 22.78 & 24.97 & 33.65 & 35.6 & 37.9 & 34.6 \\
\hline consumption & 82.47 & 81.07 & 62.84 & 68.43 & 81.07 & 80.5 & 77.1 & 67.1 \\
\hline Dust and sludge & 2.29 & 2.36 & 2 & 2.45 & 2.36 & 2.4 & 2.5 & 2 \\
\hline
\end{tabular}

ancludes prompt Industrial and obsolete scrap. Source: Adapted from Ref. 1. 
Kus1k and Brodrick both argue that energy use depends on scrap type and recovery method. Table 9.2 gives their estimates. If the 1980 percentages of home (56\%), prompt (19\%), and obsolete (24\%) scrap are used as weights for the energy intensities in Table 9.2, an average of between 0.34 $x 10^{6} \mathrm{Btu}$ (Kusik) and $0.7 \times 10^{6} \mathrm{Btu}$ (Brodrick) is obtained for each ton of scrap melted. In terms of the type of scrap purchased, Kusik considers that low-phosphorus plates; highest-quality electric furnace bundles, turnings, bushels, clips, and borings; slag scrap; and cast iron borings are primarily prompt industrial scrap, and the rest is primarily obsolete. Additional savings arise because the electric furnaces, continuous casters, and rolling mills that melt, cast, and form steel from scrap use less energy than their counterpart processes in the integrated mills. Thus, energy savings are substantial when steel made from scrap is substituted for steel made from 1ron ore.

Although the thrust of their argument is correct, several caveats should be mentioned. First, an increase in the amount of scrap recycled without some decrease in the amount of hot metal produced will increase, not decrease, the nation's energy use. The goal 18 not simply to encourage increases in scrap recycling indiscriminately, but to encourage the substitution of either scrap for hot meta1 in existing furnaces, or of new scrap-based furnaces for ore-based furnaces. Without such substitution, no energy will be saved. If increases in recycling are associated with an increase in steel output as domestic firms seek to recapture markets lost to steel imports, energy use w111 increase.

Second, the actual energy savings when scrap steel substitutes for hot iron varies, depending on the circumstances surrounding the substitution. Three 1ssues affect the estimates:

- How much energy 18 used to collect, sort, process, and deliver old and new obsolete scrap? Since most prompt industrial scrap 1s quickly recycled (except during poor market perlods, when some 18 not recycled at a11), the substantially lower amount of energy used to recycle it is irrelevant, since additional scrap for recycling will come 
from obsolete scrap. Further, collection of old obsolete scrap may be fairly energy-intensive, since it involves some transportation from remote areas. 31,36

- How much energy is saved by the simpler steel-forming activities associated with products made from scrap steel? Such savings should not be attributed to the substitution of scrap for hot metal, since these products could also be made in integrated mills.

- How much energy 18 consumed by hot metal production? As Sec. 7 on blast furnaces indicated, by-product gas credits from coke ovens and blast furnares rnnstdorably rcduce the large amount of energy apparently consumed in this process. This study estimates $19.31 \times 10^{6} \mathrm{Btu} / \mathrm{ton}$; other estimates range higher (e.g., Battelle's $23 \times 10^{6}$ Btu/ton ${ }^{33}$ ) or lower.

Brodrick and Kusik both also give recent data on the amount of energy used to recycle obsolete scrap. Brodrick calculates the average to be around $1.8 \times 10^{6} \mathrm{Btu} / \mathrm{ton}$, with the $\mathrm{mlx}$ of auto hulks to other obsolete scrap being the major determining factor 36 If the scrap were from auto hulks alone, the energy use would be $2.4 \times 10^{6} \mathrm{Btu} / \mathrm{ton}$; if it came from other scrap, the amount would be $1.8 \times 10^{6} \mathrm{Btu} / \mathrm{ton}$. This figure includes both the direct and indirect energy necessary to produce the scrap; Brodrick did not distinguish between them in his analysis. Since the Indirect requirements are a substantial fraction of total use, care must be taken to unfformly compare both the direct and indirect energy requirements betwoen the scrap recycie and integrated mill steel routes. Kusik cites a range of $0.34 \times 10^{6} \mathrm{Btu} / \mathrm{ton}$ to $1.28 \times 10^{6}$ Btu/ton, with an average of $64 \times 10^{6} \mathrm{Btu} / \mathrm{ton}$; $^{31}$ again, the range 18 due to varlance in the source of scrap.

The energy saved as a result of the simpler post-melting processes associated with $100 \%$ scrap steel products can be substantial. Substitution of continuous casters associated with scrap remelting for the ingot formation and remelting process found in most integrated mills saves an estimated $5 \times 10^{6}$ Btu/ton. 24 The simpler hot- and cold-rolling and heat treating processes for mint-mills saves a small additional amount per ton. These oavings are frequently incorrectly attributed to scrap substitution, when in fact they are due to differences between the downstream processes and final products made in mini-mills and integrated mills.

Energy use in the process of ironmaking must also be calculated with care. Mining and transportation of the ore, coal, and limestone must be 1ncluded. Energy credits associated with offgases produced at the coke ovens ( $500 \mathrm{Btu} / \mathrm{ft}^{3}$ ) and blast furnaces $\left(95 \mathrm{Btu} / \mathrm{ft}^{3}\right.$ ) should be deducted. Calculation in this manner yields a per ton energy. use estimate of $20-24 \times 10^{6}$ Btu/ton of hot metal produced (see Sec. 7). 
To summarize, the correct comparison to make for energy savings purposes is the direct and indirect energy used in scrap recycling versus the direct and indirect energy used in hot metal production. Taking all factors into account, the spread of savings is likely to fall in the range of 10-11 $\mathrm{x}$ $10^{6} \mathrm{Btu} / \mathrm{ton}$, considerably below the $17 \times 10^{6} \mathrm{Btu} / \mathrm{t}$ on savings claimed by supporters of scrap recycling. 94

\subsection{SUPPLY AND DEMAND FOR SCRAP}

Several features of the industry's supply-and-demand picture should be mentioned. For example, most integrated mills, which can obtain hot metal from blast furnaces and revert scrap from their finishing mills, are not normally major scrap purchasers, although some exceptions exist. (During the recent steel output contraction, at least one integrated mill entered the market as a seller of revert scrap.) However, in times of rapid increase in steel production, the integrated mills have temporarily turned to the purchased-scrap market for help in expanding their 1n-process inventory. This demand for purchased scrap is volatile, because it is linked to this output by an "accelerator" - or stock adjustment - mechanism. Foundries, although accounting for on 1 y $20 \%$ of total steel output, purchase almost one-third of all the scrap bought by the steel industry because scrap is their sole raw material.

\subsubsection{Sources of Scrap}

Revert scrap is always recycled immediately (within 10 days) or sold, since storage is a costly option for steelmakers. Mini-mills generate less revert scrap per ton of steel produced than the integrated $\mathrm{mills}$ because of their use of continuous casting and their concentration on steel products that require fewer steps.

Prompt Industrial scrap supply is directly related to steel fabrication throughput, which 18 closely tled to durable goods output. This scrap is so desirable that it commands a premium price and is almost immediately recycled. Hogan calculates that $16.6 \%$ of fabricated steel returns to the mills as prompt scrap; the figure is $16.8 \%$ for foundries. 20

There are two types of obsolete scrap -- current and old. "Current" obsolete scrap is scrap brought Into scrapyards and 1mmediately processed and shipped. It includes auto hulks just off the street, steel from structures recently torn down, and any other scrap that does not sit in a scrapyard in an unprocessed state. It 18 less costly to move than "old" obsolete scrap sitting in the back boneyards of scrap collection centers. Once unprocessed scrap sits outside for any length of time, the cost of recovering and processing it tincreases. 
The major source of additional scrap in periods of excess demand is "old" obsolete scrap. As prices rise, 1t pays scrap dealers to go farther and farther back into their storage areas to reclaim their old obsolete-scrap stockpiles. While some segments of the scrap-consuming industry contend that old obsolete scrap is more of a problem to use than current obsolete scrap, others conclude that scrap quality does not decrease during peak periods when more old scrap enters the market. Rather, contaminants are more a function of what went into the scrap than how long the scrap sits in a scrapyard.

Prompt and obsolete automobile scrap play a prominent role in the Industry for two reasons. First, they account for almost $40 \%$ of all prompt scrap purchased and $35 \%$ of the obsolete scrap purchased. 36 Second, because of its high quality and uniformtey, auto manufacturers and nthers are ahle tn auction oft their prompt scrap once a month to the highest bidder. The prices pald at the auctions are public knowledge and are a very effective barometer of the state of scrap demand.

\subsubsection{Elasticity of Supply}

Scrap's elasticity of supply is part of a continuous debate over scrap export controls between domest1c scrap producers and consumers. Such export limits would help the users and hurt the producers. Thus, the two trade associations -- ISIS on the supply side, and the Ferrous Scrap Consumers Coalition (FSCC) on the demand side - find themselves in continuous confrontation over fluctuations in the price and availability of scrap, and the impact of scrap exports on the fluctuations. The consumers claim that such exports reduce the obsolete scrap inventory and disproportinnately fnrreasp scrap prices, and argue that those higher prices have had little impact on supply.95,96 The producers argue that such price increases are necessary to bring forth additional scrap, and that "the supply of obsolete scrap increases promptly and substantially as the price of scrap increases."97 A ban on scrap exports, they say, would cause prices to drop; thus, the scrap would not be brought forth but would rust away unused. The demand side argues to the contrary. Each side can find support for 1 ts argument from a wide range of supply elasticities $\left(0.07^{20}-0.833^{98}\right)$, which reflect supply response to price.

A portion of this wide gap is explained by the fact that Hogan's data 20 support a very short-run supply elasticity, while the data used by Nathan 98 are more appropriate for calculating long-run elasticities. The fact that A.D. Little's estimates done for DOE are closer to Nathan's than Hogan's tends to support the ISIS point of view, but a final determination of "who is right" will inevitably turn on the issue of whether short-run or long-run elasticities are the appropriate measures of supply response to scrap export limits.

What, then, determines the elasticlty of supply for scrap? Supply elasticities are governed by the relative ease of expanding output; significant capacity expansion costs result in inelastic supply curves, unless significant excess capacity exists. 
A recent study by ISIS shows that capacity limits are not a problem in the processing portion (sorting, shredding, compacting, etc.) of the industry. 99 The study indicates that present capacity could process twice the 52 milition tons of scrap recycled in 1974 (out of $60 \mathrm{million}$ tons purchased), the largest amount recycled on record. The problem lies in collecting and transporting scrap. Transportation 18 limited primarily by the shortage of railroad gondola cars to carry the scrap. 100

\subsubsection{Elasticity of Demand}

Turning to the demand side, scrap demand elasticities are governed by (a) the degree to which products made from scrap can substitute for other products, and (b) the degree to which scrap can substitute for other inputs in the production process. The single study. of demand elasticity mentioned in the 1980 OTA report-- that of Rossegger - indicated that demand is very inelastic. 101

As to scrap product substitution possibilities, since steel made entirely from scrap (particularly old obsolete scrap) can be used to make only a fairly limited range of products, increases in scrap recycling are limited in the short run to the amounts of these products now made in the integrated mills. Since mini-mills now account for a very large percentage of such production (chiefly rebars and simple shapes), short-run substitution possibilities are quite limited. These limits can be expected to relax as time passes, since technological advances in scrap melting and impurity elimination are constantly increasing the range of products manufactured from scrap steel, even though the only practical current solution for nickel, copper, and tin impurities is to dilute them to acceptable levels.

Another possibility 18 to increase the ratio of scrap to hot metal (1ron from blast furnaces) in the integrated mills, which produce the full range of steel products. While this option does not have the quantity restrictions found in the $\mathrm{mini}-\mathrm{mill}$ route, the integrated mills are loathe to substitute a purchased raw material on which they make no profit for hot metal, an internally manufactured product in which they have a heavy investment. Thus, most substitution can be expected only as a result of the integrated mills not replacing their existing outdated hot metal capacity (blast furnaces, coke ovens, sinter plants). Such substitution is a fairly long-run process. Further, there are technical 11mits on the scrap. Hot metal charges achievable in. the BOFs, which dominate Integrated mil1s, 11mit further substitution possibilities, although a modest increase in BOF scrap charges from the "normal" 28-32\% would Increase scrap consumption by two mil11on tons.

In sum, there are $11 \mathrm{mlts}$ on the amount of scrap that can be substituted for hot metal. Thus, even though the energy savings per ton would be substantial, total energy savings would be limited by the tonnage restrictions. Over time, such restrictions should ease as scrap preheating equipment is installed 
on BOFs, allowing higher scrap charges in integrated mills. The historical stability of the hot metal/scrap ratio, and. DOE's modest (41\%) target for it in 1985, both attest to the economic and technical limits of substitution, although the appropriateness of that target has been a subject of lively discussion between the scrap iron and steel industry trade associations, since it was achieved in 1980 . 


\section{STEELMAKING}

The final step in the steelmaking process is the conversion of hot metal and scrap to steel via a refining step that removes the excess carbon left over from the smelting process and various impurities such as silicon, manganese, phosphorus, and sulfur. At the same time, various additives such as nickel, chromium, and molybdenum are injected to improve the product's characteristics.

Figures $10.1,10.2$, and 10.3 show the major components of the three types of steel furnaces now in use in the United States: the open hearth furnace, BOF, and electric arc furnace. Materials and energy flows in steel production for 1980 are given in Fig. 10.4, which is based primarily on AISI data. Direct and indirect energy use per ton varies considerably among the processes. Electric arcs are the most energy-conserving, using around $10.5 \mathrm{x}$ $10^{6} \mathrm{Btu}$ per ton (electricity valued at $10,500 \mathrm{Btu} / \mathrm{kWh}$ ), with a $100 \% \mathrm{scrap}$ charge valued at $0.7 \times 10^{6} \mathrm{Btu} / \mathrm{ton}$. Open hearths follow with around $17.3 \mathrm{x}$ $10^{6} \mathrm{Btu} / \mathrm{ton}$, and BOFs use $18 \times 10^{6} \mathrm{Btu} / \mathrm{ton}$. Table 10.1 shows the rise of the BOF, which only now is beginning to yield to the electric arc as nonintegrated mills continue to capture a larger share of the market. Using the percentages in that table as weights for the furnace energy intensities, the average direct and indirect energy used to produce one ton of raw steel in 1980 from scratch is estimated to be $15.6 \times 10^{6} \mathrm{Btu}$.

\subsection{OPEN HEARTH FURNACES}

Before 1970, the mainstay of the iron and steel industry was the openhearth furnace, but because of economic considerations and the energy crisis, a new workhorse, the BOF, has emerged. As Table 10.1 indicates, in 1980, $60 \%$ of the capacity was in BOFs, $11 \%$ in open hearths, and $28 \%$ in electric arc furnaces. Direct and indirect energy intensities per ton of steel produced in the open-hearth furnace are shown in Table 10.2 .

The open hearth furnace, which consists of a rectangular refractory hearth enclosed by refractory-lined walls and roof, is first charged with scrap and a small amount of limestone. After the fuel (which may be oil, natural gas, $\mathrm{CO}$, tar and pitch, or all four) has been ignited and the melting of the charge has begun, the proportioned amount of molten pig iron is charged and high-purity oxgen is blown in. After various minor operations, the molten steel is tapped, with a total cycle time of 8-12 hours. The open hearth can take a wide range of hot metal/scrap charges, compared with the BOF, which has a limited range. The more modern BOFs can take up to $28 \%$ scrap, but the older ones are more limited. Thus, as the BOFs replaced the open hearths, the mil1 as a whole lost much of its hot metal/scrap flexibility. This in part is why the electric furnace is coming into its own in the integrated plants, serving as the "swing" facility when scrap is scarce or plentiful. The combination of 


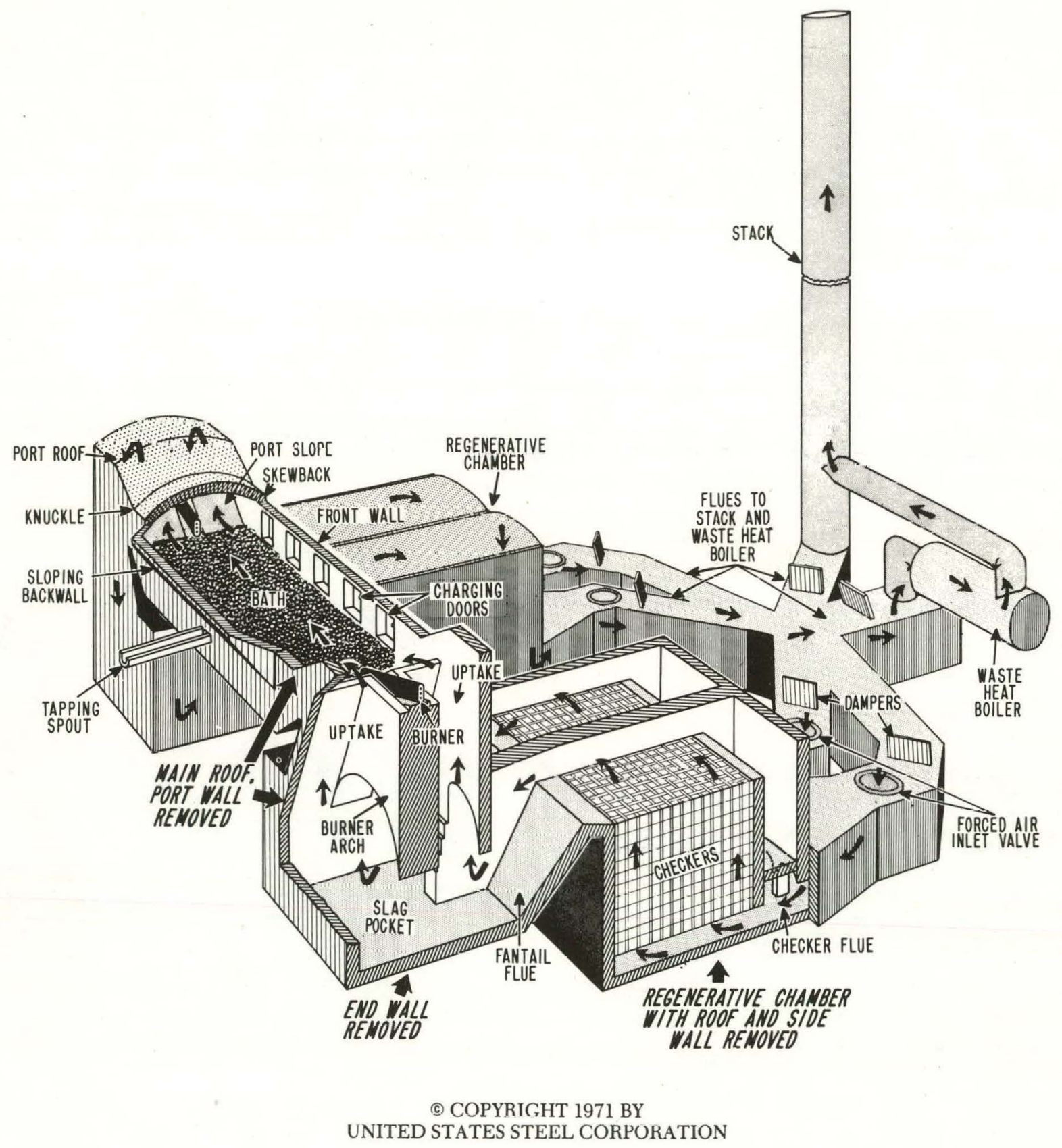

Fig. 10.1 Typical Open Hearth Furnace (arrows show direction of flow of preheated alı, flame, and waste gases) (Source: Ref. 75) 


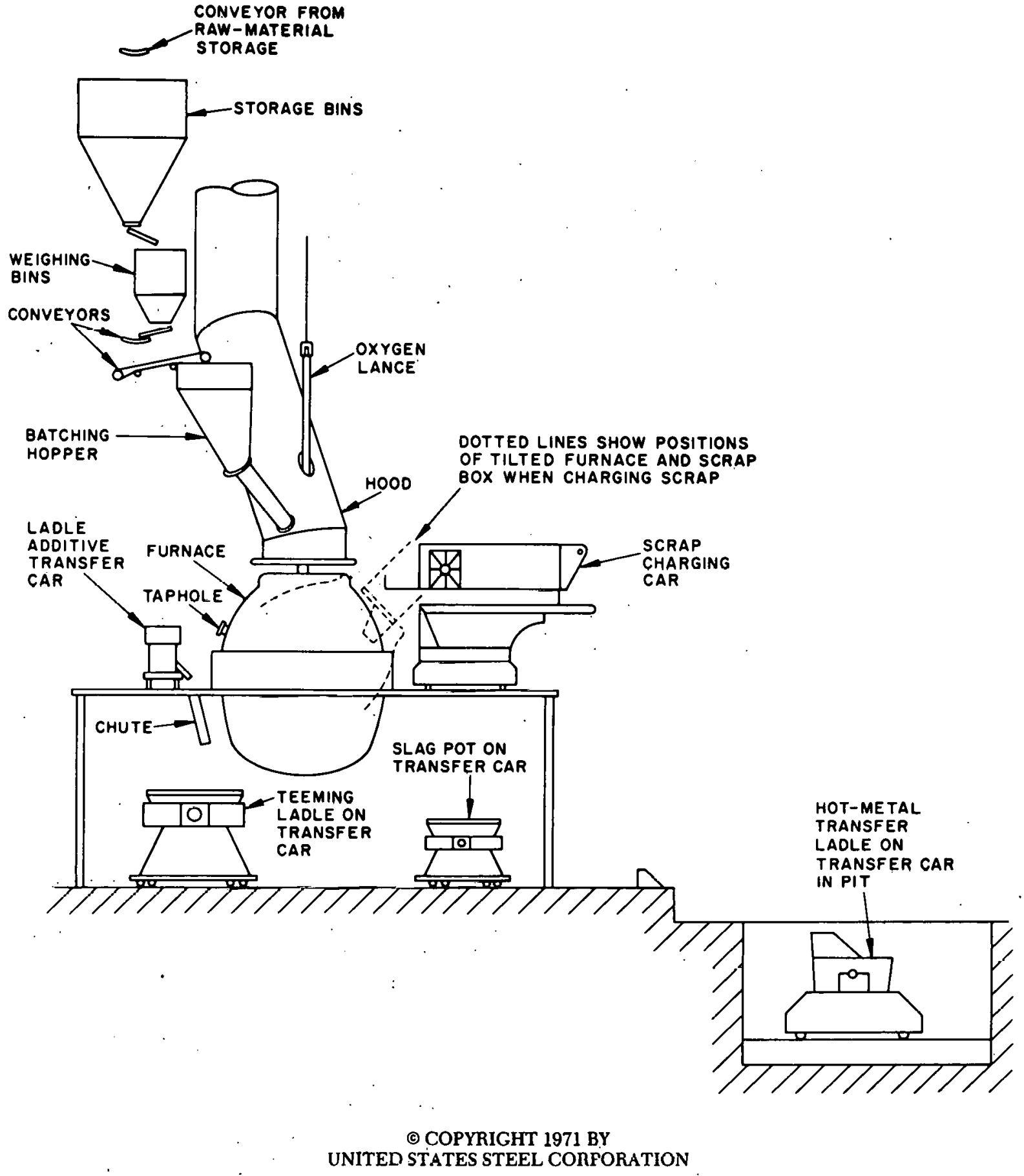

Fig- 10.2 Typical BOF (Source: Ref. 75) 


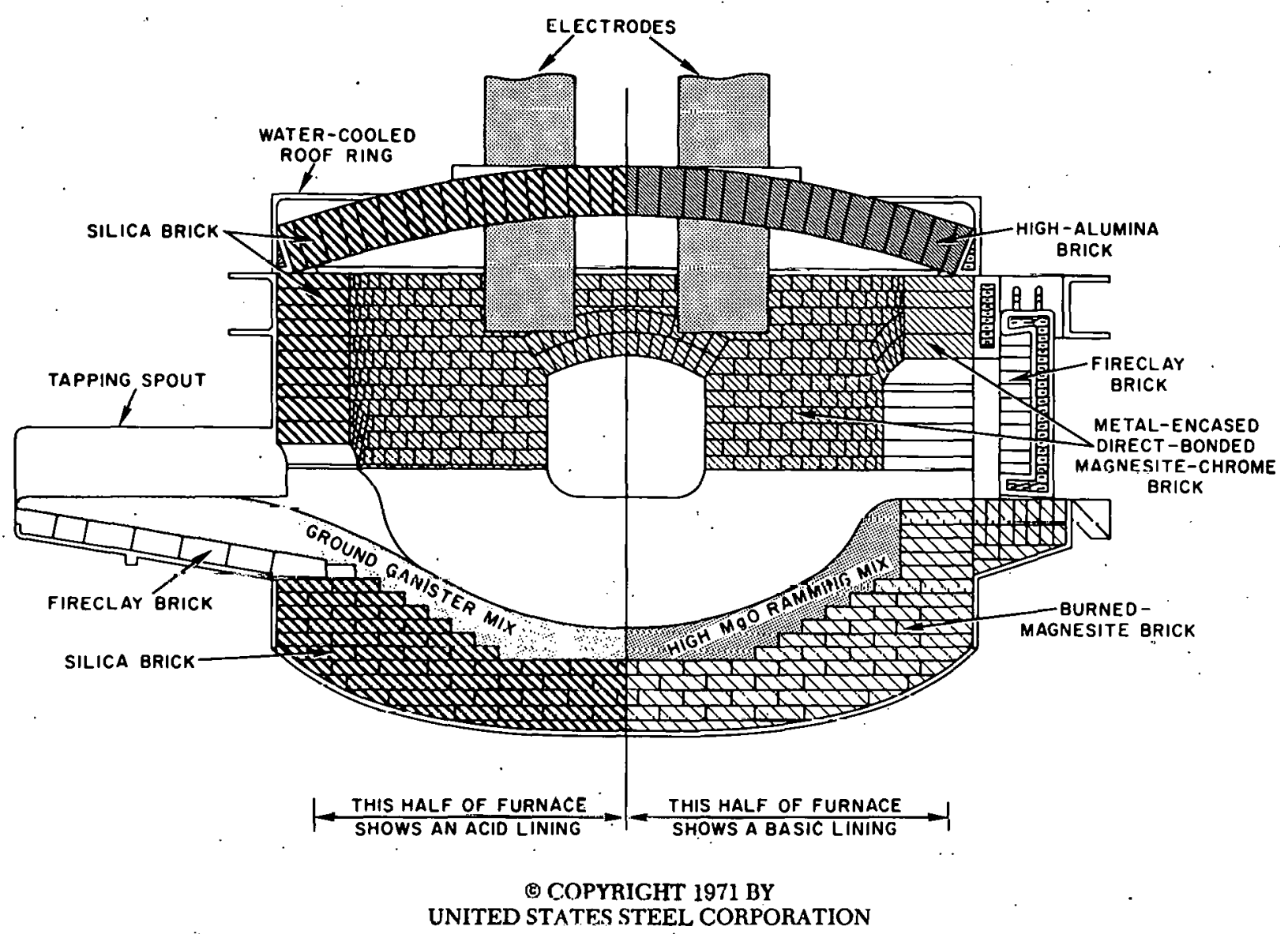

Fig. 10.3 Typical Electric Arc Furnace (Source: Ref. 75)

the very-efficient $B O F$ and versatile electric arc spelled the end for the open hearth as a major steel melting technology. Many expect it to go the way of the Bessemer in the mid-1980s, although during boom periods it has a tendency to take on new life.

\subsection{BASIC OXYGEN FURNACES}

The BOF is very different from the open-hearth furnace. It is a pearshaped vessel which, at the beginning of its cycle, is tilted al $45^{\circ}$ to accommodate a scrap charge (up to $30 \%$ of the charge) and then the molten pig iron charge. After the ladle is turned upright, high-purity oxygen is injected via a water-cooled lance located at the top of the vessel. The key to the $B O F$ is the use of the heat of reaction of the injected oxygen with the charge constituents (in particular, the carbon) to fully melt the charge; in most instances, scrap acts as a coolant. Supplementary fuel is used only occasionally when the charge contains scrap in excess of $28 \%$. With the melt maintained at $2500^{\circ}-2900^{\circ} \mathrm{F}$, the necessary chemical reactions take place, after which the molten steel is poured into transfer cars for transportation to either an ingot-pouring platform or to a continuous-casting machine. 


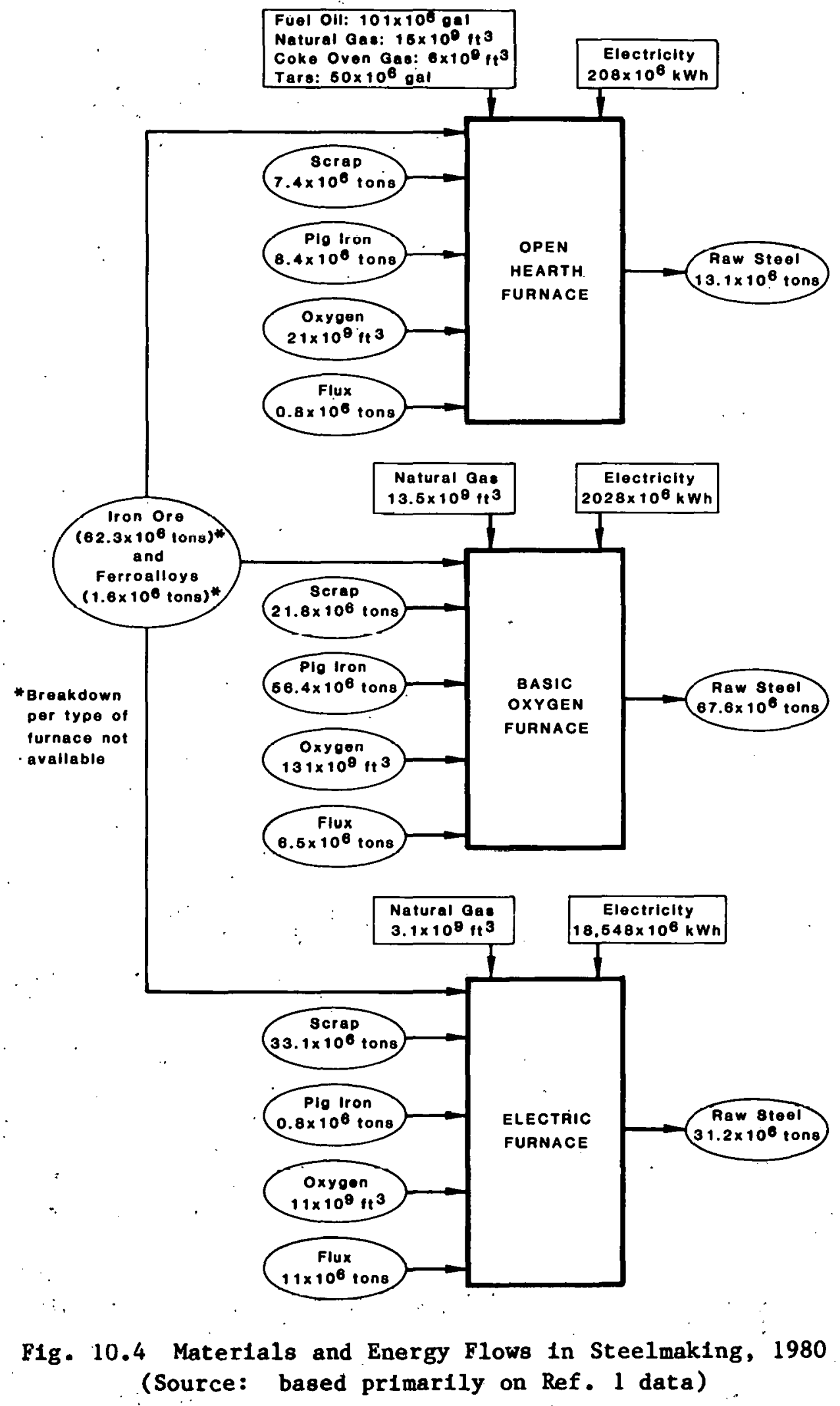


Table 10.1 Raw Steel Production by Type of Furnace, 1960-1980

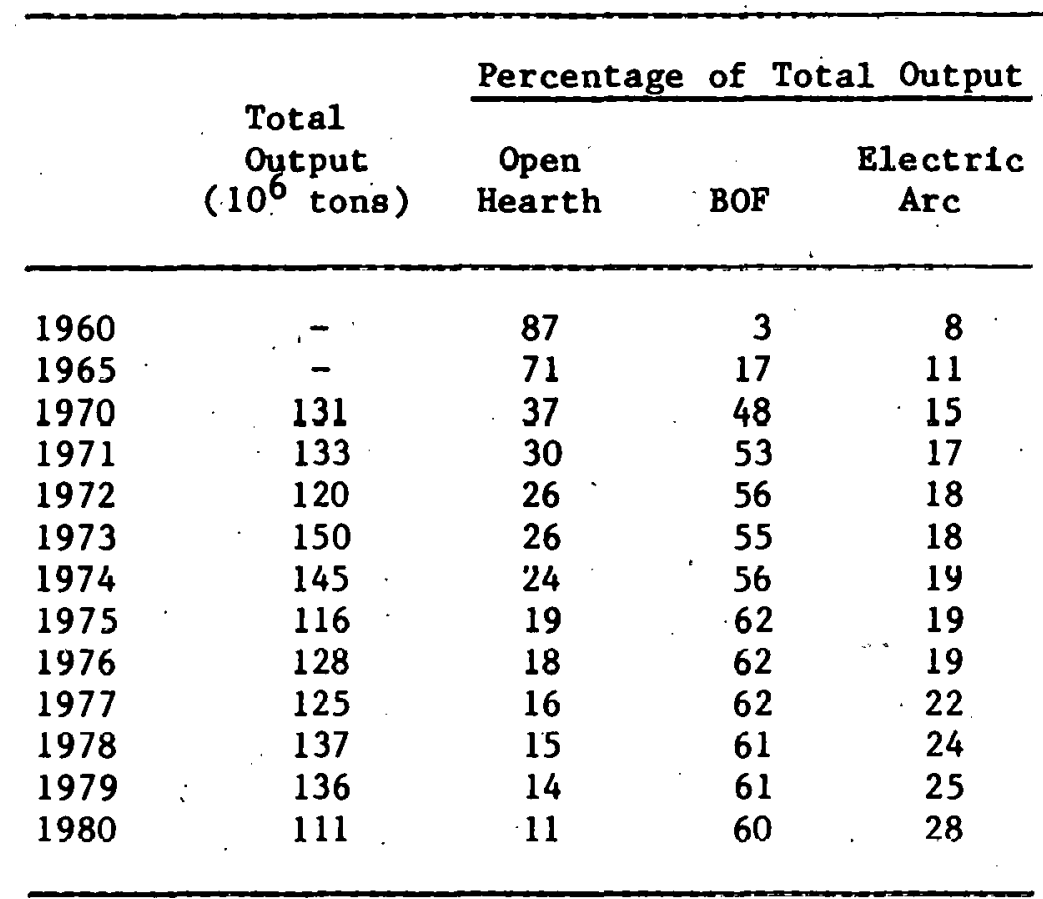

Source: Ref. 59.

The tremendous advantage of the BOF is its total cycle time of 45 minutes, compared with the open hearth's 4 to 8 hours; this results in total cost savings of $12-15 \%$ over the open hearth, as well as substantial energy savings for a given metal mix, despite higher material costs.38 (The reason Tables 10.1 and 10.2 do not reflect these savings is because they have differing hot metal/scrap ratios.) With BOFs replacing open hearths at a rapid rate and with the limitations on the amount of scrap that can be charged Into a BOF, integrated plants are relying on the electric arc furnace to process the excess scrap.

Table 10.3 gives direct and indirect energy consumption per ton. The energy intensities would be lower than for the open hearth if it were not for the fact that the BOF uses less scrap per ton than the open hearth.

The offgases generated during the BOF cycle might be utilized if the economics dictated $1 t .102$ The gases are generated in sufficlent-quantity $(565,000 \mathrm{Btu} / \mathrm{ton}$ of $\mathrm{steel})$ and quality $\left(250-300 \mathrm{Btu} / \mathrm{ft}^{3}\right.$ at $3000^{\circ} \mathrm{F}$, which adds $127,000 \mathrm{Btu} / \mathrm{ton}$ ) to warrant attention. ${ }^{7} \mathrm{All}$ BOFs have hoods of some sort to direct the escaping gases. Since the gases are at $3000^{\circ} \mathrm{F}$, and since further combustion. of CO takes place in the hoods (unless it 18 suppressed, as in Armco's Middleton plant), these hoods have to be steam- or water-cooled, dropping the temperature of the gases sufficlently to allow them to be further 
Table 10.2 D1rect and Indirect Energy Consumption in Open Hearth Steel Production, 1980

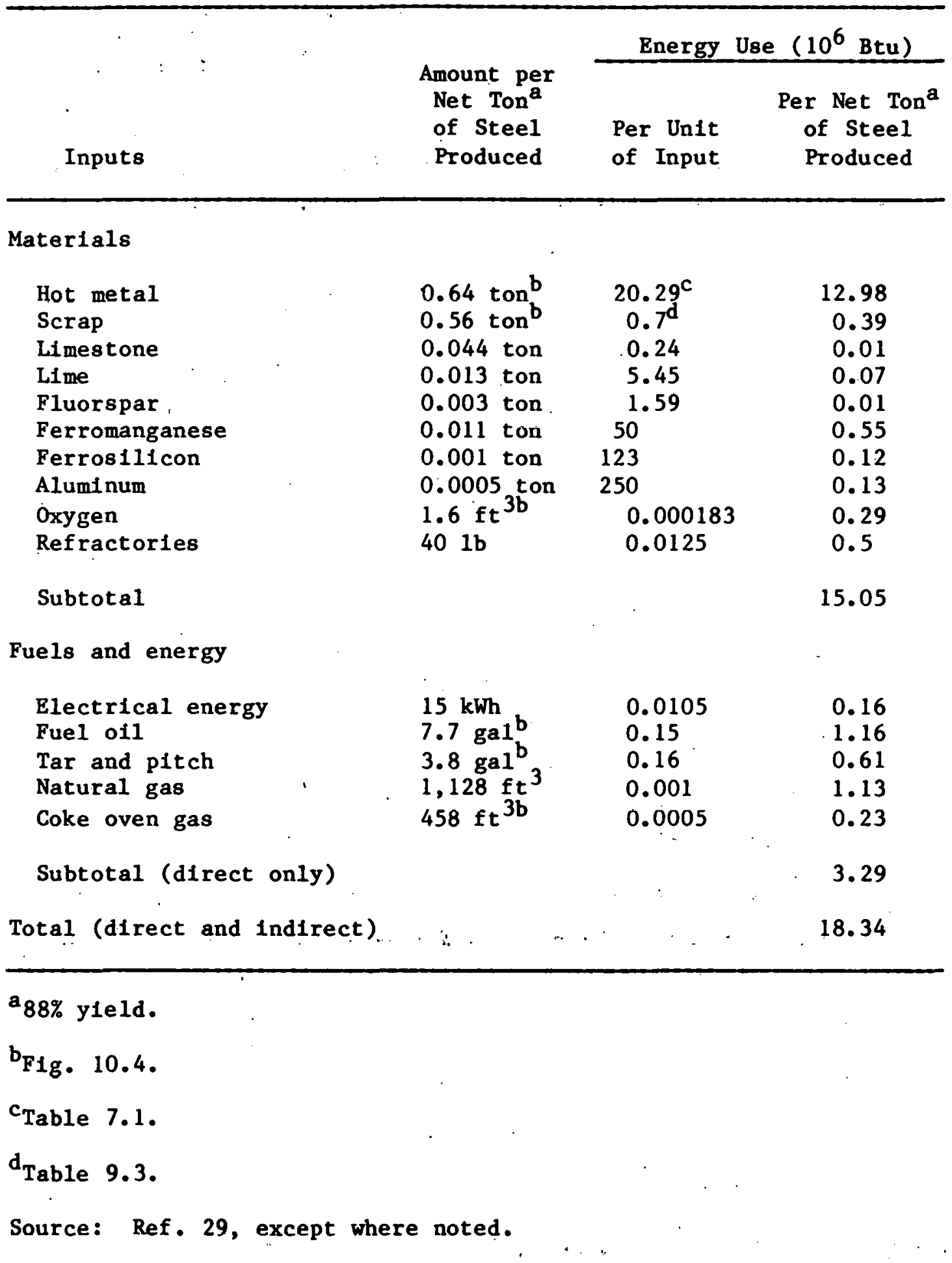


Table. 10.3 Direct and Indirect Energy Consumption in Bas1c Oxygen Stee1 Production, 1980

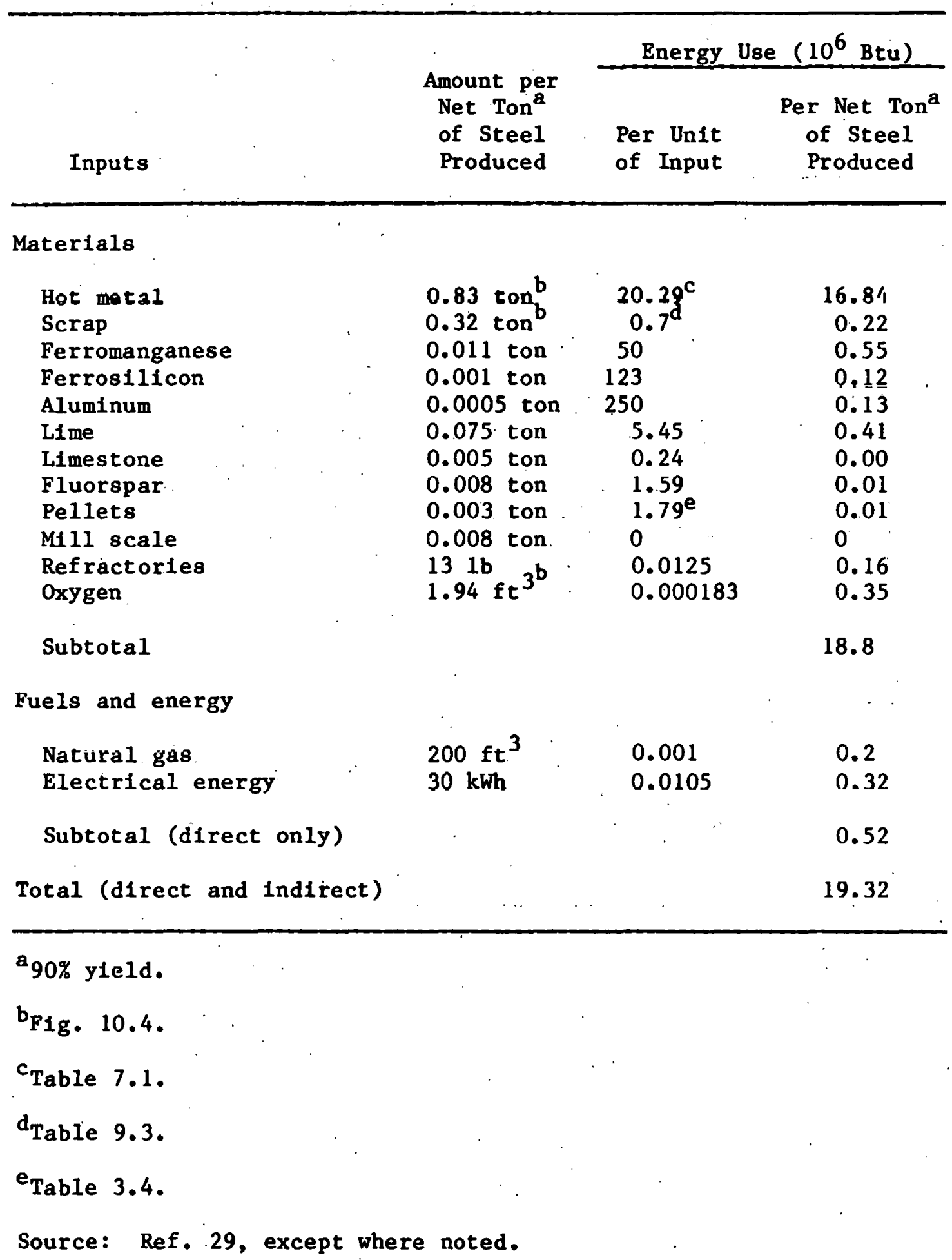


cleaned before release to the atmosphere. When steam 18 generated in this way, the energy recovered is estimated to be in the $150,000-250,000 \mathrm{Btu} / \mathrm{t}$ on range. 30 other possibilities include limiting the combustion of the offgas by collecting it in a closed hood system and using it elsewhere in the plant,or completely combusting the gases to flre large bollers located directly over the facility. According to Thermo Electron, all the gases so collected are currently not being recovered, since the intermittent nature of the gas availability and high capital costs ( $\$ 18-25$ million, Including a gas holder to hold the gas until use) make it uneconomical to utilize this source. 39 The potential energy savings from such a system have been estimated to be in the $0.6-1.0 \times 10^{6} \mathrm{Btu} / \mathrm{t}$ on range, along with some electricity savings. 30

One use of the gases so collected would be to preheat the scrap charge to the BOF, allowing a higher scrap percentage charge to such furnaces. This is particularly important, since the upper limit on BOF scrap has required that some integrated mills install electric arc furnaces (which have $100 \%$ scrap charge capabilities) to handle periods of high scrap avallability as open hearths are retired. If a means could be found to increase the limit on BOF scrap charges, such "swing" facilities might not have to be constructed. The U.S. Bureau of Mines conducted a serles of tests at its pilot plant BOF to check the feasibility of this idea. The results. were encouraging, and showed that the scrap charge percentage could be increased from $28 \%$ to $40 \% .103$

Scrap preheating need not be limited to use of BOF offgases; Indeed, a far simpler method is to inject oxygen and fuel into the scrap portion of the charge. However, this results in severe refractory lining wear and decreased furnace avallability. 8 Consequently, other processes, such as the OBM-S process modification, might have to be used. 104 A.D. Little estimates that if all BOFs were converted to gas injection or to OBM-S systems, approximately $2.48 \times 10^{6} \mathrm{Btu} / \mathrm{t}$ on of steel could be saved.15 A more realistic (but unspecified in the report) market penetration assumption would produce savlngs of between $0.6 \times 10^{6} \mathrm{Btu}$ and $1.8 \times 10^{6} \mathrm{Btu} / \mathrm{ton}$ of steel produced. ${ }^{8}$

\subsection{ELECTRIC ARC FURNACES}

Two types of electric furnaces are used to melt steel -- the electric arc and the electric induction furnace. In the arc furnace, an arc jumping between three electrodes suspended in the charge melts the metal. The induction furnace melts the charge in a refractory crucible surrounded by a copper conduction coll. 37 Only the arc furnace is used for refining, since slag cannul be maintalned or removed in the induction process. Its main advantages are complete flexibility of the charge composition and exact control of process.

Table 10.4 gives the direct and indirect energy Intensities for electric arc furnaces. Electrlcity consumption per ton varles from $450 \mathrm{kWh} / \mathrm{ton}$ for modern furnaces producing carbon steel (Industry estimate) to $740 \mathrm{kWh} / \mathrm{ton}$ for furnaces of the same age producing alloy or stainless steel. 105 
Electric arc capacity was estimated to be 26 million tons in 1972,57 of which 5.9 million tons were in nonintegrated mills.6 Since then, mini-mill capacity has grown to 13 million tons; mini-mills are now the only segment of the industry adding significantly to its capacity. 6

Scrap preheating has been tried in electric arcs as well as BOFs, both to replace high-cost electric energy with lower-cost fuels and to increase productivity. In 1961, the Bureau of Mines demonstrated that $30 \%$ of the melting energy could be provided this way. 106 Later tests confirmed these findings. Since the substitution appears to take place on a Btu-for-Btu basis, it saves energy, since fuels production 18 more efficient than electricity production. In another experiment, the residual heat remaining in billets, Ingots, and molds was used to preheat scrap in a Canadian electric arc furnace; energy savings of $20 \%$ were reported. 107 Numerous experiments and reports of ongoing operations abroad are reported by Sheridan. 108 
Table 10.4 Direct and Indirect Energy Consumption in Electric Furnace Steel Production, 1980

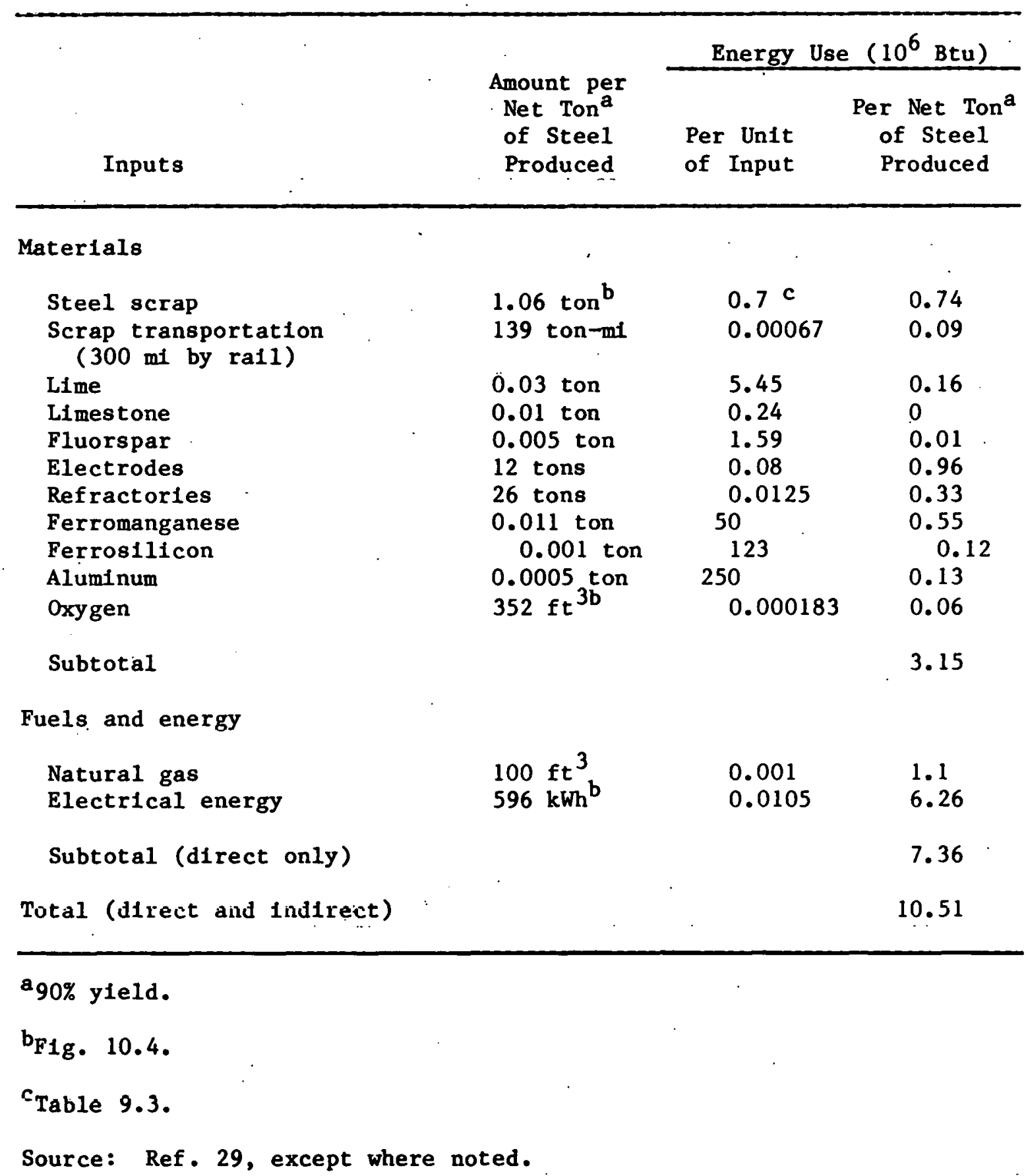




\section{SUMMARY AND CONCLUSIONS}

As Table 11.1 indicates, opportunities are plentiful for saving energy throughout the iron and steel industry over and above the roughly $10 \%$ reduction per ton achleved since 1973. Little research effort was required to achieve that $10 \%$ savings or w11l be required in the future. Th1s is partiy because, in the past, 11ttle attention was pald to the more exotic technologies (nuclear steelmaking, continuous steelmaking) for specific energy-saving purposes. Rather, the new generation of steelmaking technologies was expected to drastically improve all the traditional industry input mixes and performance measures, and only incidentally alter energy consumption.

Why are existing "best practice" technologies not displacing less energy-efficlent technologies? AISI has concluded that many are aimply not profitable enough investments for the capital-short iron and steel industry; payback perlods are too long because of high capital costs and/or Insufficient fuel savings. 71 The latter will be remedied if fuel prices increase at the 2$3 \%$ real rate that many government and industry experts predict. Others argue that the industry, faced with a constant or shrinking market in the last few years, cannot afford to purchase new equipment except to replace old. This limits drastically the introduction of energy-saving technologies, since as a general rule the cost of retrofitting existing equipment with conservation options is higher than the incremental cost of purchasing a new piece of equipment with the option built in.

Whatever the reason, while many of the options in Table 11.1 are no more than "best practice," there is 11ttle indication that the domestic iron and steel industry could or should make these technologies "average practice," given present costs of capital and energy prices.

Several other recent studies of the industry have reached simflar conclusions. In a report for DOE, A.D. Little concluded that "few programs with large energy-conserving potential will be undertaken and pursued to completion within the near term without some form of government incentives." 109 "In a more recent document, A.D. Little indicated that, of 13 conservation technologies analyzed, none required anything but development and demonstration activities to speed commercialization: the technologies were already proven. 8

The opinion that basic research in steelmaking is not really necessary Is not supported everywhere. The OTA report concludes that."the Industry could adopt new steelmaking Innovations if the Federal Government supports basic research in steelmaking (which barely exists today), .....110 The body of the report, however, does not seem to support th1s conclusion. When discussing changes in technology, the report by in large concentrates on speeding the introduction of existing technologies. Indeed, of the six major technologies discussed at length (direct reduction, direct steelmaking, plasma steelmaking, direct casting, formcoke, and continuous casting), only two -direct casting and plasma steelmaking - have much technological uncertainty 
Table 11.1 Summary of Potential Areas for Energy Conservation In Iron and Steel Manufacture

\begin{tabular}{|c|c|c|}
\hline Production Step & Energy Conservation Opportunities & $\begin{array}{l}\text { Stage of } \\
\text { Development }\end{array}$ \\
\hline Mining & $\begin{array}{l}\text { Few, outside of larger loading/hauling equipment, } \\
\text { importation of ore }\end{array}$ & $\mathrm{C}$ \\
\hline Crushing & Improve comminution with existing and new technologies & $C, D$ \\
\hline Separation & $\begin{array}{l}\text { Remove cationic silica; } \\
\text { floculate Iron oxide; } \\
\text { use more-efficient magnets }\end{array}$ & $\begin{array}{l}\mathbf{R} \\
\mathbf{R} \\
\mathbf{C}\end{array}$ \\
\hline Induration & $\begin{array}{l}\text { Install heat recuperation facilities on all plants; } \\
\text { substitute coal for hydrocarbons; } \\
\text { use grate-kiln and traveling-grate shaft furnaces } \\
\text { lul un-slle cual gas Iflullull; } \\
\text { use partial reduction of pellets }\end{array}$ & $\begin{array}{l}\text { C } \\
\text { C } \\
\text { D } \\
\text { D }\end{array}$ \\
\hline Sinter planes & $\begin{array}{l}\text { Use binderless briquetting; } \\
\text { use direct reduction of blast furnace and BOF wastes; } \\
\text { recover sensible heat of sinter plant gases }\end{array}$ & $\begin{array}{l}\text { D } \\
\text { D } \\
\text { C }\end{array}$ \\
\hline Coke production & Nine options given in Table 6.6 & $C, D, R$ \\
\hline Blast furnace & $\begin{array}{l}\text { Use higher top pressures, plus expansion turbines; } \\
\text { increase air blast temperatures; } \\
\text { optimize burdens; } \\
\text { use coal injection; } \\
\text { reduce blast furnace.gas loss; } \\
\text { prereduce Iron burden in lower stack; } \\
\text { preheat ore with latent heat of coke and sinter; } \\
\text { use blast furnace gas to preheat stove alr; } \\
\text { use heat in slag }\end{array}$ & $\begin{array}{l}\text { C } \\
\text { C } \\
\text { C } \\
\text { C } \\
\text { C } \\
\text { R } \\
\text { D } \\
\text { D } \\
\text { R }\end{array}$ \\
\hline Direct reduction & Use coal-based processes. & C \\
\hline Scrap & $\begin{array}{l}\text { Develop cheaper shredders to } 1 \text { ncrease scrap recycle } \\
\text { rate; } \\
\text { Change scrap transport prices to better reflect costs }\end{array}$ & $\begin{array}{l}\text { D } \\
\text { D }\end{array}$ \\
\hline Steelmak Ing & $\begin{array}{l}\text { Recover BOF of fgas; } \\
\text { Use scrap preheaters for BOFs and electric arcs } \\
\text {. }\end{array}$ & $\begin{array}{l}\text { C } \\
\text { D }\end{array}$ \\
\hline
\end{tabular}

${ }^{a_{R}}=$ research stage; $. D=$ development stage; $C=$ commerclal stage. 
surrounding them, and even for direct casting, none of the proposed systems represents the application of new basic principles.

As In all industries where the product is both durable and recoverable, substantial energy savings can result from increased scrap recycling. Increased recycling activity in iron and steel is currently hampered by distortions in the relationship, between the price paid to collect and move scrap and the true cost of such collection and movement. Perhaps with increased deregulation of the transportation industry, true costs and prices will. come into line, making secondary recovery more profitable.

There are, of course, limits on scrap recovery; scrap must be "mined" and any substantial increase in the recycle rate can be done only at a cost, which might include having to limit exports, not a happy prospect for the scrap supply industry.

Iu summary, this scudy joins others in concluding that the role of government research and development in iron and steel high-technology projects is probably small compared with that. In other industries. (e.g., copper/lead, where smelting technology that is energy-efflcient, cost-effective, and in compliance with the Clean Alr and Water Act simply doesn't exist). However, there is a need for new, Innovative government policles that would make it profitable for firms to capitalize on the developed technologies that await them at the "best practice" margin. 


\section{REFERENCES}

1. Annual Statistical Report, American Iron and Steel Institute, Washington, D.C. ( 1980$)$.

2. Gaines, L., Energy and Materials Flows in the Copper Industry, Argonne National Laboratory Report ANL/CNSV-11 (Dec. 1980).

3. Economics of the Minerals Industries, 3rd ed., American Institute of Mining, Metallurgical, and Petroleum Engineers, New York (1976).

4. Cummings-Saxton, J., Automobile Materials Competition: Energy Implications of Fiber-Reinforced Plastics, Argonne National Laboratory Report ANL/CNSV-25 (Oct. 1981).

5. The U.S. Automobile Industry, 1980, U.S. Dept. of Transportation, Transportation Systems Center, Washington, D.C. (Jan. 1981).

6. Technology and Steel Industry Competitiveness, office of Technology Assessment, Washington, D.C. (June 1980).

7. Material Applications in Future Automobile Structure, Vol. II, Budd Company Technical Center, prepared for U.S. Dept. of Transportation and National Highway Transportation Safety Assoc., NTIS PB80-124845.

8. A.D. Little, Inc., Life Cycle Energy Requirements for Selected Sheet Materials Applicable to Manufacture of Automobile Components, report to American Iron and Steel Institute, Washington, D.C. (March 1981).

9. Renewable Resources for Industrial Materials, National Research Council, Washington, D.C., p. 151 (1979).

10. Hannon, B., Materials, Energy, and Labor Impacts in Typical Building Floor Bay Assemblies, Univ. of Illinois (Aug. 1978), as cited in Ref. 6, p. 178 .

11. Iron Age (March 17, 1980).

12. Iron Age (Oct. 8, 1979).

13. Iron Age (May 7, 1979).

14. Iron Age (Oct. 22, 1979).

15. A.D. Little, Inc., Industrial Recovered Materials Utilization Targets for the Metals and Metals Froducts Industry, U.S. Dept. of Energy Report SAN/1692-T1 (March 1980). 
16. Iron Ore 1980, American Iron Ore Assoctation, Cleveland (1980).

17. Membership Directory, American Iron and Steel Institute, Washington D.C. (1980).

18. Environmental Considerations of Selected Energy-Conserving Manufacturing Process Options, Vol. III: Iron and Steel Industry Report, U.S. Environmental Protection Agency Report EPA-600/7-76-034C (Dec. 1976).

19. R.R. Nathan Associates, Inc., Iron and Steel Scrap, prepared for the Institute of Scrap Iron and Steel, Washington, D.C. (1977).

20. Hogan, W.T., and F.T. Koelbe, Purchased Ferrous Scrap, prepared by Fordham Universicy for the American Iron and Steel Institute, Washingtion, D.C. (June 1977).

21. 19\%7 Census of Manujactures: Industry Statistics (SIC 3312, Blast Furnaces and Stesl Mill6), U.S. Dept. of Commerce, Bureau of the Census, Washington, D.C.

22. Energy Consumption and Stocks: Blast. Furnaces and Steel Mills, 1979 and 1978 , U.S. Dept. of Commerce, Bureau of the Census, Washington, D.C. (Dec. 1980).

23. Report to U.S. Department of Energy on Energy Efficiency Improvement, American Iron and Steel Institute, Washington, D.C. (varlous reporting years, 1972-1981).

24. Darby, J.B., Jr., and R.M. Arons, Energy and Materials Flows in the fiabrication of Iron and StbBl Semifinished Products, Argonne National Laboratory Report ANL/CNSV-8 (Aug. 1979).

25. The Input/Output Stmucture of the U.S. Economy, 1972, U.S. Dept. of Commerce, Washington, D.C. (Feb. 1979).

26. Hannon, B., et a1., Energy Analysis Handbook, Energy. Research Group Doc. 214, Univ. of Illinois, Champaign-Urbana (Oct. 1976).

27. Shen, S.Y., and A.M. Wolsky, Energy and Materials Flows in the Production of Liquid and Gaseous Oxygen, Argonne National Laboratory. Report ANL/CNSV-15 (Aug. 1980).

28. Coke and Coal Chemicals, U.S. Energy Information Agency, Energy Data Report, Washington, D.C. (Oct. 1980).

29. Energy Use Patterns in Metallurgical and Nonmetallic Mineral Processing, Phase 4, Battelle Columbus Laboratorles, Columbus, NTIS No. PH-245-759 (June 27, 1975). 
30. A.D. Little, Inc., Research; Development, and Demonstration for Energy Conservation, Preliminary Identification of Opportunities in Iron and Steel Making, U.S. Dept. of Energy Report SAN/162-1 (Jan. 1978).

31. Kusik, C.L., and C.B. Kenahan, Energy Use Patterns for Metal Recycling, U.S. Dept. of Interior Information Circular 8781 (1978).

32. Coke and Coal Chemicals in 1979, U.S. Energy Information Agency, Energy Data Report, Washington, D.C. (Dec. 1980).

33. Evaluation of the Theoretical Potential for Energy Conservation in Seven Basic Industries, Battelle Columbus Laboratorles, Columbus, NTIS No. PB244772 (July 11, 1975).

34. Coke and Coal Chemicals in 1980, U.S. Energy Information Agency, Energy Data Report, Washington, D.C. (Nov. 1981).

35. Iron dind steel tingineer (Dec. 1978).

36. Brodrick, J.R., Energy Conservation in the U.S. Economy from Increased Recycle of Obsolete Steel Scrap, Energy Research Group Doc. 264, Univ. of Illinois, Champaign-Urbana (Nov. 1978).

37. The Potential for Energy Conservation in Nine Selected Industries, Vol. 6: Steel, Gordian Associates, New York (1974).

38. Kakala, P., Pelletized vs. Natural Iron Ore Technology -- Energy, Labor, and Capital Changes, Energy Research Group, Univ. of Illinols, ChampaignUrbana (Dec. 1977).

39. A Study of Improved Fuel Effectiveness in the Iron and Steel and Paper and Pulp Industries, Thermo Electron Corp., Waltham, Mass. (March 1976).

40. Bravard, J.C., H.B. Flora, and C. Portal, Energy Expenditures Associated with the Production and Recycle of Metals, Oak Ridge National Laboratory Report ORNL-NSF-EP-24 (Nov. 1972).

41. Kraus, H.R., Mineralogy, McGraw-Hi11, New York (1952).

42. Minerals Yearbook, U.S. Bureau of Mines, Washingtion, D.C. (1976).

43. Gelb, B.A., Energy Use in Metal Mining: A Study in Trade-Off6, The Conference Board Record, Conference Board, New York, pp. 17-20 (Ju1y 1976).

44. Annual Report, American. Iron Ore Association, Cleveland (various years, 1971-1980). 
45. Berzins, A., et al., The Future of Sintering in the U.S., 38th Ironmaking Proc., American Institute of Mining, Metallurgical, and Petroleum Engineers (1979).

46. Census of Mineral Industries, U.S. Bureau of the Census, Washington, D.C. (1977).

47. Industrial Energy Use Data Book, Oak RIdge Associated Universities Report ORAU-160 (1980).

48. Energy Consumption Data. Base, Vo1. III, EEA, Inc., Arlington, Va., p. 250 (1977).

49. Comminution: Energy Consumption, Nat1onal Research Counc1l, Washington, D.C., NAUB-364 (1981).

50. Hirsch, H., Energy Requirements in Minnesota Iron Ore and Taconite Mining, Minnesota Energy Agency Research Divison, St. Paul (Aug. 1975).

51. Wakeman, J.S., Energy Efficiency Considerations in Iron Ore Pelletizing, Mining Congress Journal (May 1981).

52. Ashworth, R.A., et al., Gas from Coal for Iron Ore Pelletizing, 37th Ironmaking Proc., American Institute of Mining, Metaliurgical, and Petroleum Englneers (1979).

5.3. Hoyt, E., III, The Outlook for Iron Ore, Mining Congress Journal (Dec. 1980).

54. Pietrucha, W.E., and R.L. Deily, Steel Industry in Brief: Data Book, U.S.A.: 1979-80, Institute for Iron and Steel Studies, Green Brook,' N.J. (1980).

55. Monthly Energy Review, U.S. Dept.' of Energy, Energy Information Adm., Washington, D.C. (June 1981).

56. Current, G.P., Sinter Plant Gas Recirculation and Gravel Bed Filtration at Weirton Steel, 39th Ironmaking Proc., American Institute of Mining, Metallurgical, and Petroleum Engineers (1980).

57. Temple, Barker, and Sloan, Analyses of the Economic Effects of the Environmental Regulations on the Integrated Iron and Steel Industry, U.S. Environmental Protection Agency Report EPA 230-3-76-014B (Dec. 1976).

58. Moore, J.E., Production of Blast Fumace Feed from Mill Waste Iron Oxide by Hot Compaction, 36th Ironmaking Proc., American Institute of Mining, Metallurgical; and Petroleum Engineers (1977). 
59. Kanda, K., Direct Reduction Process for Iron Industries Waste Fines, 36th Ironmaking Proc., American Institute of Mining, Metallurgical, and Petroleum Engineers (1977).

60. Annual Statistical Reports, American Iron and Steel Institute, Washington, D.C. (various years, 1972-1980). .

61. Preheating the Mix on the Centering Machine, 37th Ironmaking Proc., American Institute of Mining, Metallurgical, and Petroleum Engineers, pp: 438-444 (1978).

62. McManus, G.J., U.S. Coke Oven Capacity Reaches The Crisis Stage, Iron Age (March 3, 1980).

63. Hogan, W.T., and F.T. Koelbe, Analysis of the U.S. Metallurgical Coke Industry, prepared for the U.S. Economic Development Administration and LeHigh University (Oct. 1979).

64. Sparrow, F.T., The Iron and Steel Process Model, Brookhaven National Laboratory Report BNL-51073 (1980).

65. Industrial Intemational Data Base: The Steel Industry, Gordian Associates, New York (1977).

66. Energy Use Patterns in Metallurgical and Nonmetallic Mineral Processing, Phase 8, Battelle Columbus Laboratorles, prepared for U.S. Bureau, of Mines (1975).

67. Habermehl, D., and W. Rohde, Widening of Coking Coal Resources by Precarbon, 38th Ironmaking Proc., American Institute of Mining, Metaliurgical, and Petroleum Engineers (1979).

68. Bertling, H., Coke Dry Quenching - A Process for Recovering Energy, Iron and Steel Engineer (Sept. 1979).

69. U.S. Dept. of Energy unpublished Information (Feb. 2, 1981).

70. Energy Conservation in the Iron and Steel Industry, American Iron and Steel Institute, Washington, D.C. (May 1976).

71. Savitz, M., An Assessment of the Formcoke Process, report prepared for Congress by the U.S. Dept. of Energy, Office of Industrial Programs, Conservation and Solar Energy Office (June 10, 1980).

72. Ralph M. Parsons Co., Proposal Review: Inland Steel Formcoke Demonstration Project, U.S. Dept. of Energy Final Report, Contract \#DE-AC07-80CS40448, p. 6 - 6 (June 1980). 
73. Clarlmbol1, J.P., Non-Recovery Coke Making - Past, Present, and Future, Iron and Steel Englneer (June 1979).

74. Minerals Yearbook, U.S. Bureau of Mines, Washington, D.C. (1980).

75. The Making, Shaping and Treating of Steel, 9th ed., U.S. Steel Corp., Pittsburgh (1971).

76. Woolf, P.L., Improved Blast Furnace Operation, in Efficient Use of Fuels in the Metallurgical Industries, Conf. Proc. of the Institute of Gas Technology, Ch1cago (Dec. 9-13, 1974).

77. U.S. Steel Research Laboratory, Compilation of Reports on Direct Reduction Technology and Economics, U.S. Dept. of Energy Report \#10010095 (June 1981).

78. Vicard, G., High Yield, Low Energy Blast Fumaces, 35th Ironmaking Proc., American Institute of Mining, Metallurgical, and Petroleum Engineers, New York (1976).

79. Emerson, S.D., A Systems Study of Desulphurization Strategy in Relation to the Sulphur and Ash Content of Coking Coals; Ph.D. dissertation, Univ. of Arizona, Dept. of Metallurgical Engineering (1979).

80. Ref. 77, p. VIII-3.

81. McManus, G.J., Armeo's Coal Injection System Bought by Nippon, Iron Age (March 1980).

82. Tenenbaum, M., Reflections on Steel's Energy Maze, 85th General Meeting, American Irọn and Steel Institute, Washington, D.C. (May 1977).

83. Hall, E.H., Thermodynamic Analysis of Industrial Energy Conservation Opportunities, Symp. on Environment and Energy Conservation, U.S. Environmental Protection Agency, Research Triangle Park, N.C. (Aug. 1976).

84. Priestner, W.J., Air Preheater System For Blast. Fumace Stoves, 35th Ironmaking Proc., American Institute of Mining, Metallurgical, and Petroleum Engineers (1976).

85. Monsanto Research Corp., Slag Waste Heat Recovery and Utilization in the Elemental Phosphorus Industry, U.S. Dept. of Energy Report, NTIS No. CONS-5088-1 (Apri1 1978).

86. Iron and Steel Engineer, pP. D-7 through D-8 (Feb. 1980). 
87. Hogan, W.T., Does Direct Reduction Have a.. Future? Iron and Steel Engineer (Feb. 1981).

88. Klausmeier, W., Argonne National Laboratory, personal communication (Sept. 1981).

89. Reddy, R.H., Some Factors Affecting the Value of Direct Reduced Iron to the Steelmaker, 38th Ironmaking Proc.,. American Institute of Mining, Metallurgical, and Petroleum Engineers (1979).

90. Jensen, H.B., and R.M. Smatler,. The Handling Storage, and Shipment of Direct Reduced Iron, 39th Ironmaking Proc., American Institute of Mining, Metallurgical, and.Petroleum Engineers (Feb. 1980).

91. Leary, R.J., and G.M. Larwood, Effects of Direct Reduction Upon Mineral Supply Requirements for Iron and Steel Production, U.S. Bureau of Mines Information Circular 8583 (Dec. 1973).

92. Ref. 90, p. 44.

93. Recycling Ferrous Scrap Can Save Energy, Iron and Steel Engineer (Sept. 1978).

94. Recycling Iron and Steel Scrap Saves Energy, undated: pamphlet, Institute of Scrap Iron and Steel, Washington, D.C.

95. Kaplan, I.M.J., The Consumer's Viewpoint, Proc. of the Ferrous Scrap Consumer's Coalition, Washington, D.C. (Feb. 1980).

96. Nehmer, S., Effects of Exports on Price of Scrap, Proc. of the Ferrous Scrap Consumer's Coalition, Washington, D.C. (Feb. 1980).

97. Phoenix Quarterly, Institute for Scrap Iron and Steel, Washington, D.C. (1980).

98. Price-Volume Relationship for the Supply of Scrap Iron and Steel, R.R. Nathan Associates, Washington, D.C. (Jan. 1979).

99. Phoenix Quarterly, Institute for Scrap Iron and Stee1, Washington, D.C. (Summer 1976).

100. Phoenix Quarterly, Institute for Scrap Iron and Steel, Washington, D.C. (Spring 1978).

101. Ref. 6, p. 233. 
102. Baum, J.P., The Co-system For BOP Gas Cleaning, 60th Basic Oxygen Furnace Proc., American Institute of Mining, Metallurgical, and Petroleum Engineers (1976).

103. Mahan, 60th Basic Oxygen Furnace Proc., American Institute of Mining, Metallurgical, and Petroleum Engineers, p. 124 (1976).

104. McManus, G.J., Flexibility of Scrap Charge Key to Furmace Concept, Iron Age (Feb. 4, 1980).

105. Energy Consumption in. Manufacturing, Ford Foundation, New York, p. 451 (1976).

106. Remalia, D.L., Scrap Preheating for Increased Productivity, 37th Electric Arc Proc., American Institute of Mining, Metallurgical, and Petroleum Engineers (1979).

107. Woolworth, H.R.'; and J.S. Shannon, The Utilization of Waste Thermal Energy in the Process of Preheating Scrap Metal, 36th Electric Arc Proc., American Institute of Mining, Metallurgical, and Petroleum Engineers (1978).

108. Sheridan, A.T., Energy Use in Scrap Preheating, Ironmaking and Steelmaking, No. 4 (1975).

109. Ref. 30, p. I-6.

110. Ref. 6, P. 3 . 


\section{Distribution for ANL/CNSV-41}

Internal

$\begin{array}{llll}\text { J.G. Asbury } & \text { L.L. Gaines } & \text { P.A. Nelson } & \text { A.M. Wolsky (228) } \\ \text { M.J. Bernard (2) } & \text { W. Harrison } & \text { E.G. Pewitt } & \text { ANL Contract Copy } \\ \text { L. Burris } & \text { A.S. Kennedy } & \text { J.J. Roberts } & \text { ANL Libraries (3) } \\ \text { E.J. Croke } & \text { A.B. Krisciunas } & \text { N.F. Sather } & \text { ANL Patent Dept. } \\ \text { J.J. Dzingel } & \text { M.L. Kyle } & \text { T.G. Surles } & \text { TIS Files (6) } \\ \text { B.R.T. Frost } & \text { K.S. Macal (2) } & \text { R.W. Weeks } & \end{array}$

\section{External}

U.S. Department of Energy Technical Information Center, for distribution per UC-95f (253)

Manager, U.S. Department of Energy Chicago Operations office (DOE-CH)

Energy and Environmental Systems Division Review Committee:

E.E. Angino, University of Kansas

H.J. Barnet $t$, Washington University

B.A. Egan, Environmental Research and Technology, Inc., Concord, Mass.

W.H. Esselman, Electric Power Research Institute, Palo Alto, Calif.

N.C. Mullins, Indiana University

J.J. Stuke1, University of Illinois

J.J. Wortman, North Carolina State University

F.L. Corban, Inland Steel Co., East Chicago, Ind.

G.R. Curtis, Armco, Inc., Middletown, Ohio

H. Cutler, Institute for Scrap Iron and Steel, Washington, D.C.

J.R. Dudak, National Steel Corp., Pittsburgh

J.H. Fatum, Pickands Mather \& Co., Cleveland

J.H. Gibbons, office of Technology Assessment, U.S. Congress

D.R. Gill, Lukells, Inc., Coatesville, Menn.

G.W. Houck, American Iron and Steel Institute, Washington, D.C.

W. Jackson, U.S. Steel Corp., Pittsburgh

D.E. Kash, University of Oklahoma

R. Leidner, Bethlehem Steel Corp., Bethlehem, Penn.

H.W. Lownie, Battelle Columbus Laboratories, Columbus, Ohio

S.V. Margolin, A. D. Little, Inc, Cambridge, Mass.

R.W. Martin, Northwestern Steel \& Wire Co., Sterling, Ill.

L. Mims, Illinols Department of tinergy and Natural Resources, Chicago

T.L. Nabors, Republic Steel Corp., Cleveland

T. Schuerger, U.S. Steel Research Laboratories, Monroeville, Penn.

R.L. Sheneman, U.S. Department of Energy

F.T. Sparrow, Purdue University (20)

L.B. Stoner, Jones \& Laughlin Corp., Pittshurgh

P. Werbos, U.S. Department of Energy

T. Williams, Purdue University 